\title{
Republic of Tajikistan: 2011 Article IV Consultation, Fourth Review Under the Three-Year Arrangement Under the Extended Credit Facility, Request for Waiver of Nonobservance for Performance Criteria and Modification of Performance Criterion-Staff Report; Staff Supplement; and Public Information Notice on the Executive Board Discussion.
}

Under Article IV of the IMF's Articles of Agreement, the IMF holds bilateral discussions with members, usually every year. In the context of a combined discussion of the 2011 Article IV consultation with the Republic of Tajikistan and the Fourth Review Under the Three-Year Arrangement Under the Extended Credit Facility, the following documents have been released and are included in this package:

- $\quad$ The staff report for the combined 2011 Article IV consultation and Fourth Review Under the Three-Year Arrangement Under the Extended Credit Facility, Request for Waiver of Nonobservance for Performance Criteria and Modification of Performance Criterion, prepared by a staff team of the IMF, following discussions that ended on March 2, 2011, with the officials of the Republic of Tajikistan on economic developments and policies. Based on information available at the time of these discussions, the staff report was completed on April 26, 2011. The views expressed in the staff report are those of the staff team and do not necessarily reflect the views of the Executive Board of the IMF.

- $\quad$ A supplement containing the Debt Sustainability Analysis

- $\quad$ A Public Information Notice (PIN) and Press Release, summarizing the views of the Executive Board as expressed during its May 11, 2011, discussion of the staff report on issues related to the Article IV consultation and the IMF arrangement, respectively.

- A statement by the Executive Director for the Republic of Tajikistan

The documents listed below have been or will be separately released.

Letter of Intent sent to the IMF by the authorities of the Republic of Tajikistan*

Memorandum of Economic and Financial Policies by the authorities of the

Republic of Tajikistan*

Technical Memorandum of Understanding*

*Also included in Staff Report

The policy of publication of staff reports and other documents allows for the deletion of market-sensitive information.

\author{
Copies of this report are available to the public from \\ International Monetary Fund • Publication Services \\ $70019^{\text {th }}$ Street, N.W. • Washington, D.C. 20431 \\ Telephone: (202) 623-7430 • Telefax: (202) 623-7201 \\ E-mail: publications@imf.org Internet: http://www.imf.org
}

\section{International Monetary Fund Washington, D.C.}




\title{
INTERNATIONAL MONETARY FUND
}

\section{REPUBLIC OF TAJIKISTAN \\ Staff Report for the 2011 Article IV Consultation, Fourth Review Under the Three- Year Arrangement Under the Extended Credit Facility, Request for Waiver of Nonobservance for Performance Criteria and Modification of Performance Criterion.}

Prepared by the Middle East and Central Asia Department in Consultation with Other Departments

Approved by David Owen and Dhaneshwar Ghura

April 26, 2011

\begin{abstract}
Mission: Discussions were held in Dushanbe during February 17-March 2, 2011 for the 2011 Article IV Consultation and the fourth review under the three-year arrangement under the Extended Credit Facility (ECF).
\end{abstract}

Team: Messrs. Schneider (head), Junius, Al-Eyd, and Ms. Unigovskaya (all MCD), and Ms. Bal Gunduz (SPR). Mr. Aisen, the resident representative, assisted the mission.

Key Tajik officials: President Mr. Rahmon, Head of President's Office Mr. Davlatov, Minister of Finance Mr. Nadjmuddinov, National Bank of Tajikistan (NBT) Chairman Mr. Rahimzoda, and Minister of Economic Development and Trade Mr. Hamraliev.

Fund relations: A three-year, US\$116 million (90 percent of quota) arrangement under the ECF was approved by the IMF's Executive Board on April 21, 2009, and augmented to US\$152 million (120 percent of quota) on June 7, 2010 (EBS/10/95).

Exchange system: Tajikistan has accepted the obligations under Article VIII, Sections 2,3 , and 4 , and maintains an exchange system free of restrictions on payments and transfers for current international transactions. The exchange rate regime has been classified as stabilized since June 2009.

ECF: With one exception, all quantitative performance criteria through end-December 2010 were met. In the Letter of Intent (LOI), the authorities outline new structural benchmarks, updating the Memorandum of Economic and Financial Policies (MEFP) of November 9, 2010.

Data: Despite some weaknesses, data provision is broadly adequate for surveillance. Tajikistan participates in the GDDS.

Outreach: The mission met with local representatives of the donor community, including the Asian Development Bank (ADB), the World Bank, and the European Union, and briefed members of the diplomatic community. The mission also gave a press briefing. 


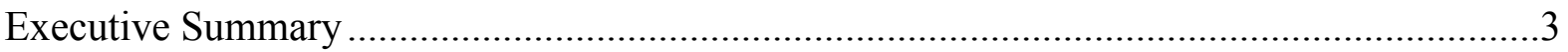

I. Overview: Recovery Gains Ground but Challenges Remain .............................................

A. Growth Returns, Inflation Rises........................................................................

B. External Accounts - Temporary Shift to Surplus ....................................................5

C. Financial Sector-Post-Crisis Problems Remain.......................................................6

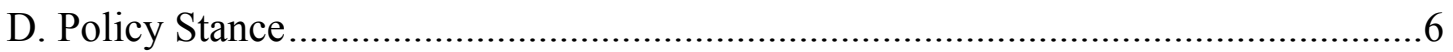

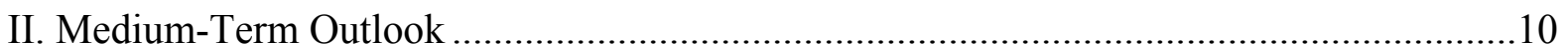

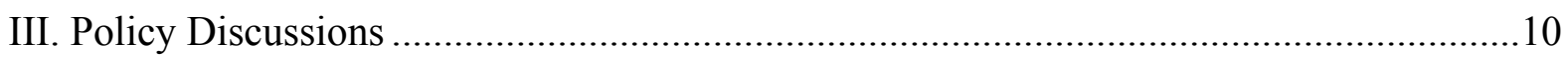

A. Coping with Price Shocks ................................................................................11

B. Financial Sector-Vulnerabilities and Policies......................................................12

C. Maintaining Fiscal and Debt Sustainability ..........................................................13

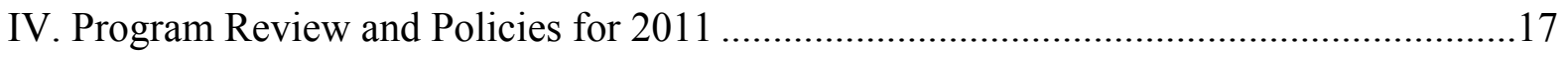

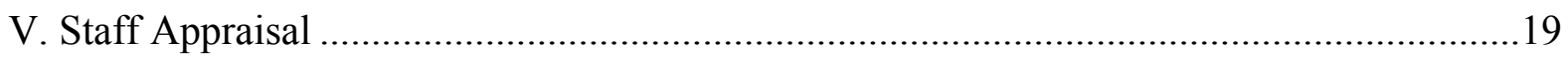

Boxes

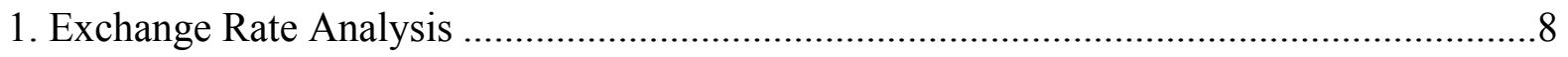

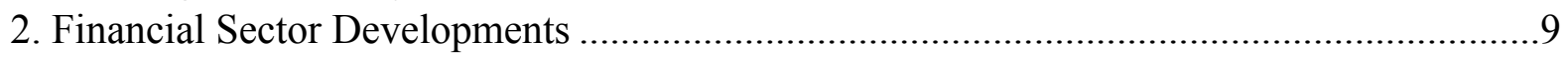

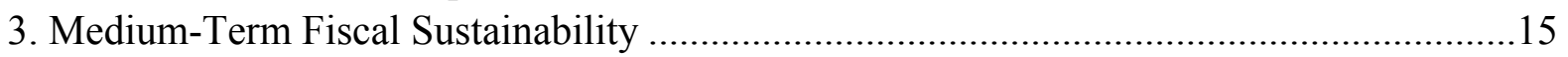

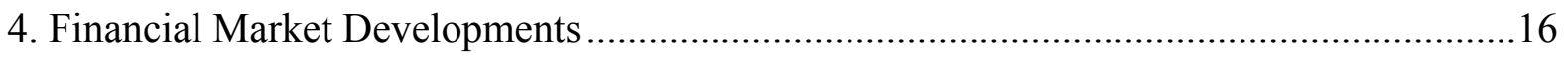

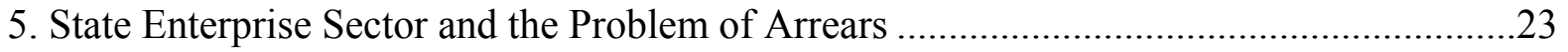

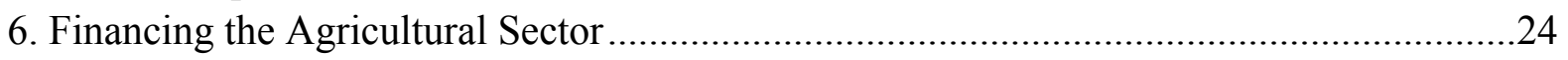

Tables

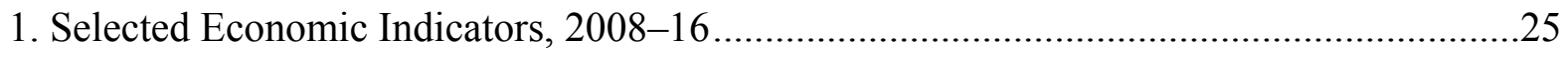

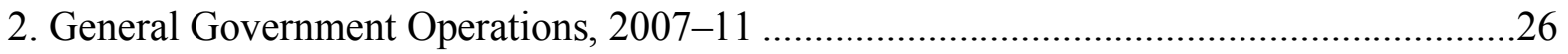

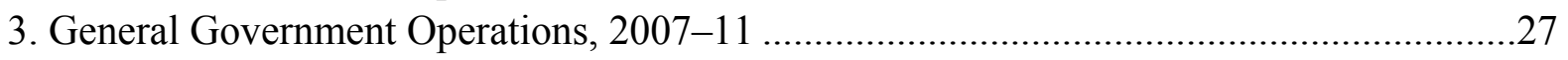

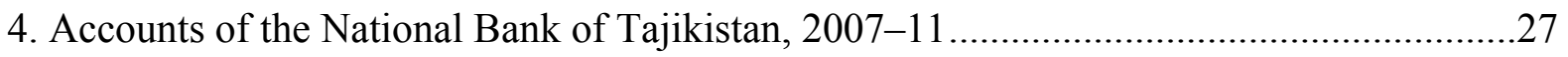

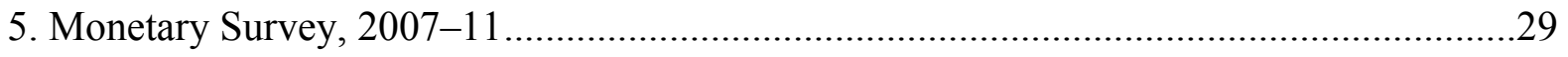

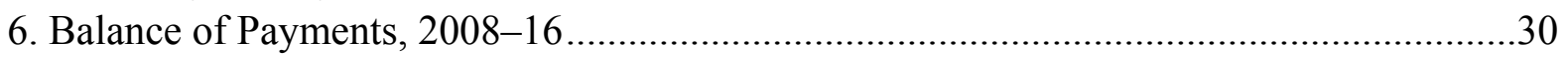

7. External Financing Requirements and Sources, 2008-15 ................................................. 31

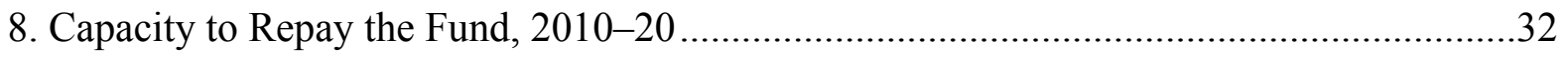

9. Reviews and Disbursements under the Three-Year ECF Arrangement, 2009-12 …..........33

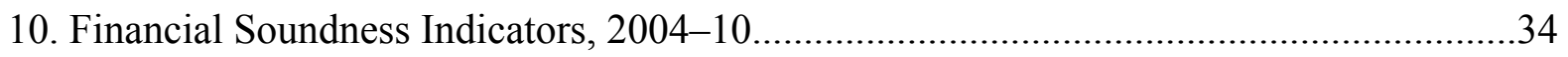

Attachments

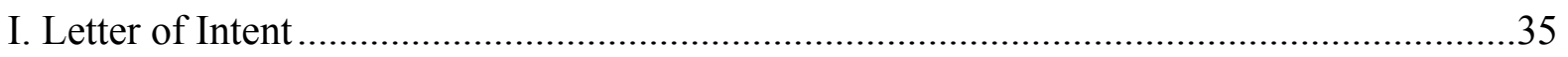

II. Memorandum of Economic and Financial Policies (MEFP) for 2009-12 ………….........43

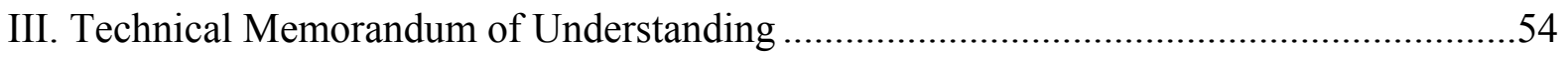




\section{Executive Summary}

Background: Tajikistan is emerging from the global crisis, with real GDP growth rising to 6.5 percent in 2010, up from 3.9 percent in 2009. A strong policy response, supported by a devaluation of the somoni, helped to facilitate adjustment, but a quick return to pre-crisis growth rates appears unlikely. The external balances improved markedly in 2010, but due to temporary factors. Inflation is now sharply on the rise, reaching nearly 10 percent by end2010, and rising further thus far in 2011. Program performance is generally good but the continuous criterion on non-accumulation of new external payment arrears was not met. Staff proposes a waiver for nonobservance of this performance criterion.

Policy Challenges: Tajikistan's principal economic challenge remains creating and sustaining levels of economic growth necessary to reduce poverty and unemployment, while also working within domestic and external resource constraints.

\section{Key Recommendations:}

- Maintain a prudent monetary stance to avoid adding pressure to core inflation. Over the medium term, develop a cash transfer system to protect the poor during price shocks.

- $\quad$ Address vulnerabilities in the financial sector, with a view to reducing the overhang of nonperforming loans, creating confidence in the banking system, and enabling higher levels of financial intermediation.

- Shift to a post-crisis view of fiscal policy. Gradually reduce the fiscal deficit to allow for a rebuilding of fiscal buffers. Reform the tax policy regime to help build revenues, make space for priority social and infrastructure spending, and create a more conducive environment for private sector growth.

- $\quad$ Continue work on agricultural reform, with a particular emphasis on creating a sustainable mechanism for agricultural finance.

- $\quad$ Make further progress in development of domestic financial markets, starting with the domestic Treasury-bill (T-bill) market. 


\section{OVERVIEW: RECOVERY GAINS GROUND BUT CHALLENGES REMAIN}

\section{A. Growth Returns, Inflation Rises}

1. Economic activity has recovered, but a return to pre-crisis growth rates appears unlikely. Tajikistan registered real GDP growth of 6.5 percent in 2010, up from 3.9 percent in 2009. Stronger hydroelectricity production helped to boost industrial activity, while trade and services benefited from a recovery of inward remittance flows (reflecting Russia's economic rebound). Construction also increased during the second half of the year. The upturn in GDP suggests that Tajikistan is emerging from the effects of the global crisis. However, a return to pre-crisis growth rates (which ranged as high as 10 percent during 2001-08) seems unlikely given that such growth was fueled in part by significant increases in remittances (based on large emigration) which may not be sustainable going forward.

\section{Inflation remained in the low single digits through the first half of 2010 , but} began to rise thereafter in line with international commodity prices-particularly grain and flour. Headline inflation reached 9.8 percent by the end of the year, with food and fuel prices accounting for the bulk of the increase. ${ }^{1}$ Core inflation (excluding food and fuel) actually fell through the course of the year, but on an annual average basis was roughly steady compared with 2009. No second-round effects have yet emerged, as the authorities exercised restraint on increases in civil service wages and salaries in 2010.
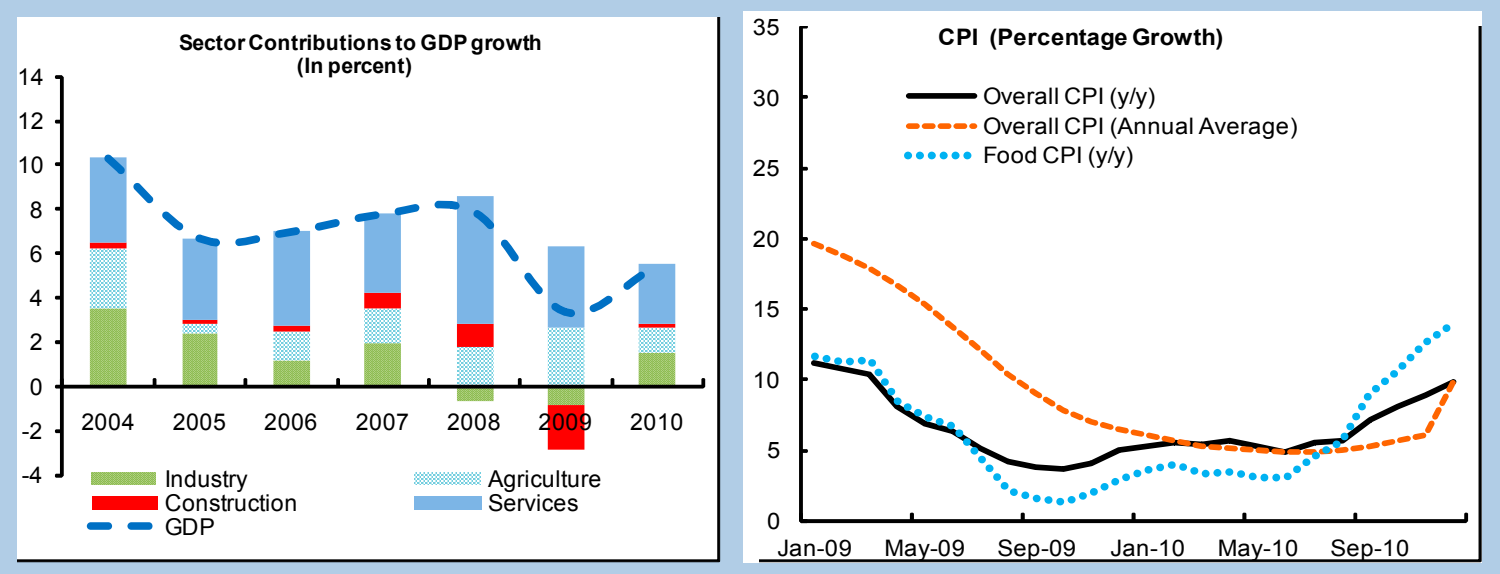

3. Tajikistan remains one of the poorest countries in the region and lags behind in a range of social and governance indices. Real per capita GDP has only recently regained the ground lost during the civil war, rising to a level (in PPP terms) comparable with such

\footnotetext{
${ }^{1}$ Data suggest that a large part of the external shocks are being passed through to domestic inflation. An increase in the world food price of 27 percent in 2010, for example, has translated into an increase in domestic food prices of 13 percent during the same period.
} 
countries as Gambia and Senegal. The UNDP's Human Development Index, ranks Tajikistan closer to such countries as Syria, Vietnam, and Morocco. However, Transparency

International ranks Tajikistan in the bottom seventh of the countries surveyed with respect to corruption, and the overall rating has changed little over the past five years. Tajikistan ranked 139 (of 183 countries) on the 2011 World Bank Doing Business indicators - gaining 10 places in 2010 due to improvement in ease of starting business and investor protection. Tajikistan has also gained some ground on EBRD transition indicators. However, much remains to be done, particularly in competition policy, securities market development, enterprise restructuring, bank reform, privatization, and infrastructure reform. Tajikistan's anti-money laundering and combating the financing of terrorism (AML/CFT) framework is weak. A draft AML/CFT law was presented to parliament in December 2010, based on technical assistance from the World Bank. However, the 2010 Voluntary Tax Compliance (VTC) program has the potential to increase the risk of money laundering.
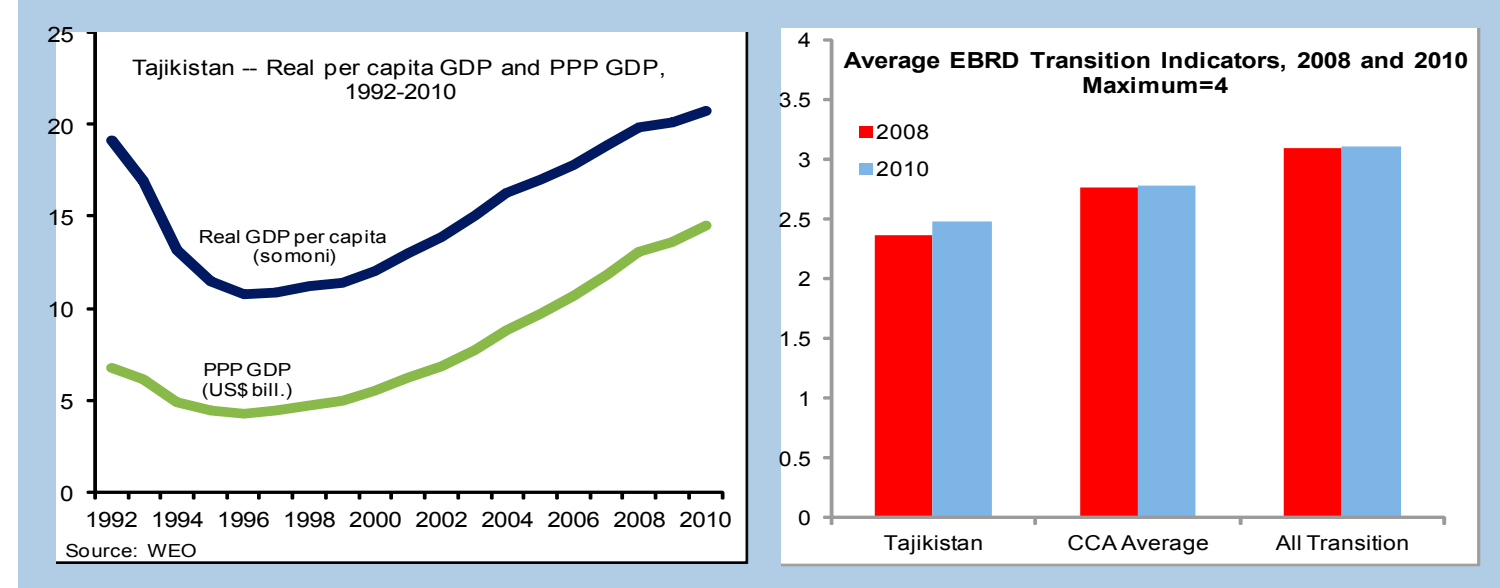

B. External Accounts-Temporary Shift to Surplus

4. The external accounts have strengthened, but the improvement is expected to be temporary. The external current account shifted to a surplus of 2.2 percent of GDP in 2010, compared with an average 5 percent deficit during 2005-09. Remittances recovered by nearly 29 percent, equivalent to a rise of almost 5 percent of GDP. Despite the pick-up in remittances (which usually entail higher imports) the trade balance improved. The lagged impact of real exchange rate depreciation, disruptions to rail transit in the first part of 2010, and a slowdown in external loan disbursements for the public investment program (PIP) underpinned this shift. The latter two factors are temporary and expected to reverse in 2011. Adverse terms-of-trade shocks from higher food prices and the full-year impact of Russian export duties on fuel are likely to be only partially offset by higher cotton prices. On balance, risks to the external accounts in the near- and medium-term are likely to be on the downside.

5. The somoni remained steady against the U.S. dollar in nominal terms, but the real effective exchange rate appreciated by 5.5 percent in the 12 months to December 2010 . 
Analysis suggests the somoni may be modestly overvalued from a medium-term perspective, highlighting the need for further exchange rate flexibility (see Box 1).

\section{Financial Sector-Post-Crisis Problems Remain}

\section{Some financial soundness indicators have improved, but frailties in key banks} remain. Private sector credit (excluding activities related to the write-off of loans held by Kredit Invest as part of the cotton sector debt resolution) recovered through the course of the year. Financial soundness indicators have also improved but remain a concern. Classified loans $^{2}$ have declined, but the extent to which this reflects a lasting improvement is uncertain. ${ }^{3}$ The two largest banks continue to account for the lion's share of classified loans. These banks are most closely associated with agricultural and state-owned enterprises (SOE) financing, and are also the two banks most often in violation of established prudential criteria. Profitability turned positive in the fourth quarter, but remains minimal. Recent gains appear fragile, and linked to restructuring of assets rather than an underlying improvement in profitability (see Box 2).

\section{Policy Stance}

7. The authorities generally maintained fiscal discipline. The overall fiscal deficit (excluding the externally financed PIP) in 2010 was 0.4 percent of GDP, compared with a budgeted deficit of 1 percent of GDP. Tax revenues suffered in the first half of the year as rail blockades impacted VAT on imports, but recovered during the second half of 2010 and ended the year in line with the indicative target under the ECF-supported program. The authorities also increased nontax revenues in an effort to keep pace with tax shortfalls in the first half of the year. Capital spending was higher than expected by about 0.75 percent of GDP_-including domestically financed capital expenditures. ${ }^{4}$ Current spending, on the other hand, was about 1 percent of GDP less than expected. This was due in large part to a decision to limit the increase in civil service wages and salaries to 10 percent rather than the envisioned 15 percent, and not to fill a number of government posts.

\section{Monetary policy was accommodative for most of 2010 , but began responding to inflation late in the year. Reserve and broad money grew by 15.8 and 26.2 percent,}

\footnotetext{
2 The authorities' data includes all classified loans — substandard (1-30 days overdue), doubtful (30-60 days), dangerous (60-180 days), and hopeless (180+ days) — as nonperforming loans.

${ }^{3}$ The norm to be applied for upgrading a given loan is uneven. Banks can upgrade a loan and reverse provisions made earlier, when the "borrower resumes stable repayment of the principal and interest", without clearly defining "stable" and the asset classification category to which the loan can be upgraded.

${ }^{4}$ About half of budget capital expenditures financed construction on the Roghun hydropower project. Spending on the Roghun project is also financed by resources raised from the public sale of shares, which amounted to about SM 830 million by end-2010, and of which some SM 200 million were spent during the year.
} 
respectively, in 2010. Higher-than-expected growth in net foreign assets was not fully compensated by a lower-than-expected increase in net domestic assets (reflecting the small fiscal deficit and a year-end drive to reduce the outstanding balance of liquidity loans to commercial banks). Policy rates were increased by 25 bps in October 2010, and by another 75 bps in March 2011. At the same time, however, liquidity support from the NBT to commercial banks started to rise sharply in the second half of 2010 and into 2011. NBT liquidity loans rose from SM 78 million at end-June 2010 to SM 265 million (1 percent of GDP) by September 2010. While this was reduced to SM 186 million by end-year, ${ }^{5}$ liquidity loans jumped to over SM 400 million (about 1.3 percent of GDP) in January 2011. Part of this increase is related to import of food and fuel products for strategic reserves, but was otherwise mirrored in rising private sector credit, suggesting that some portion of the liquidity support was on-lent.
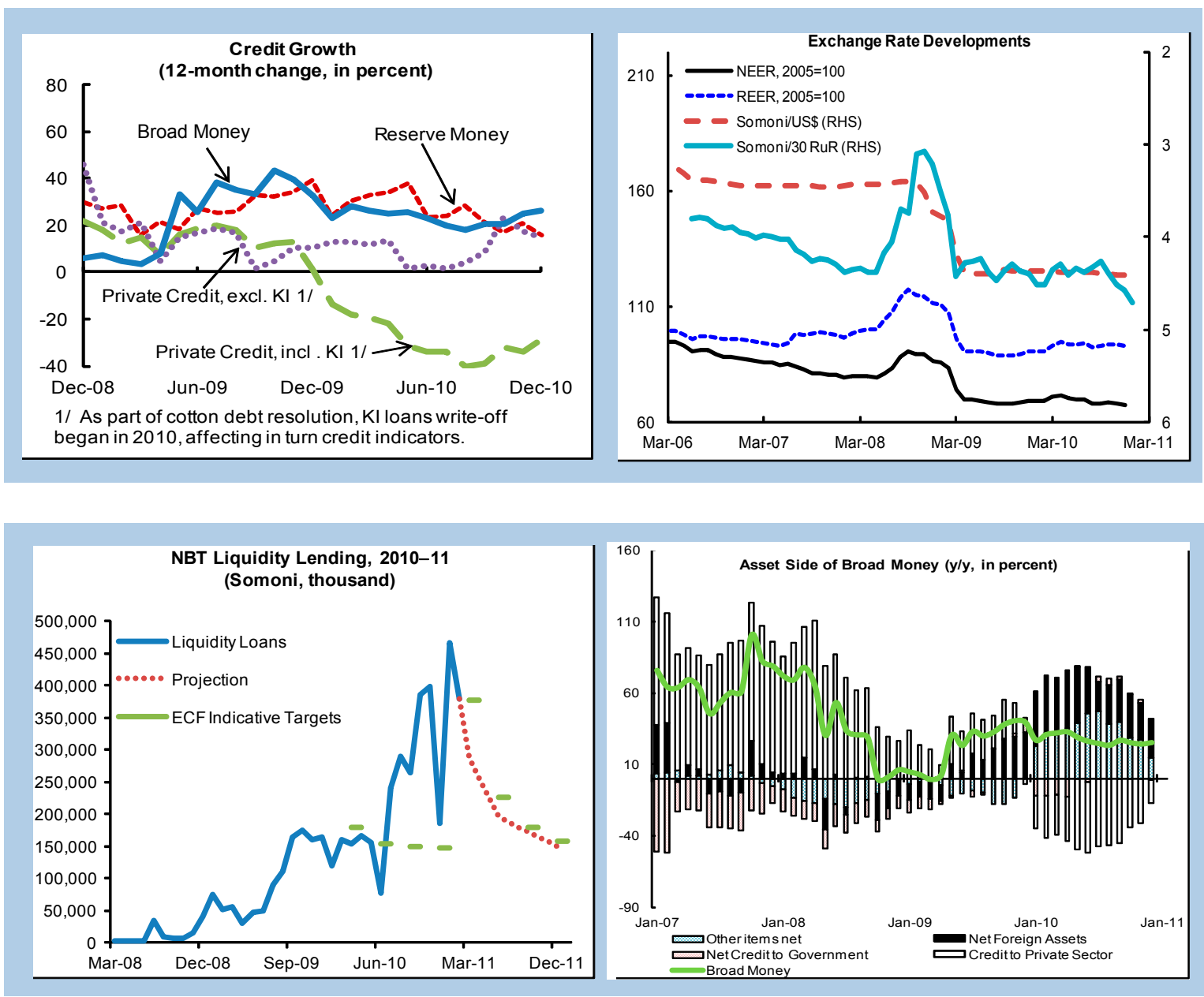

\footnotetext{
${ }^{5}$ The composition of liquidity loans changes considerably on a month-to-month basis, but at end-2010 local currency liquidity loans accounted for 90 percent of the total.
} 


\section{Box 1. Tajikistan: Exchange Rate Analysis}

Preliminary analysis based on the three CGER methodologies suggests some modest overvaluation of the somoni, in the range of 3 to 15 percent. The current level of the real effective exchange rate would become overvalued in light of the anticipated balance of payments pressures that would likely emerge in the wake of projected adverse external developments (such as the expected sharp decline in cotton prices in 2012 and increase in international food and fuel prices, based on WEO projections). Staff considers that this overvaluation is temporary, given the authorities' commitment to a flexible exchange rate policy, and history of allowing the somoni to adjust in the face of persistent shocks (such as the substantial depreciation undertaken during the global economic crisis). Given the heavy concentration of exports in cotton and aluminium, the impact on competitiveness is seen as negligible.

Tajikistan: Methodologies to Assess Real Exchange Rate Misalignment $1 /$

\begin{tabular}{lccc}
\hline & $\begin{array}{c}\text { Underlying Current } \\
\text { Account Balance 2/ }\end{array}$ & $\begin{array}{c}\text { Current Account } \\
\text { Norm }\end{array}$ & $\begin{array}{c}\text { Estimated Over(+)/ Under(- } \\
\text { ) Valuation } \\
\text { (in percentage) }\end{array}$ \\
\hline Macroeconomic Balance Approach 2/ & -5.3 & -2.2 & 15.2 \\
External Sustainability Approach 2/ & -5.3 & -2.7 & 12.6 \\
Equilibrium Real Exchange Rate Approach 3/ & $\ldots$ & $\ldots$ & 2.9 \\
\hline
\end{tabular}

Source: WEO, and IMF staff estimates.

1/ Based on CGER methodologies (SM/06/283).

2/ The macroeconomic balance approach and the external sustainability approach define misalignment as the exchange rate adjustment needed to eliminate the gap between an estimated "current account norm" and the "underlying" current account balance based on 2016 WEO projections.

$3 /$ This approach defines misalignment as the change in the real exchange rate required to eliminate the gap between actual REER and the estimated values from the regression of the equilibrium exchange rate based on current fundamentals.

Tajikistan used exchange rate flexibility in responding to the crisis.
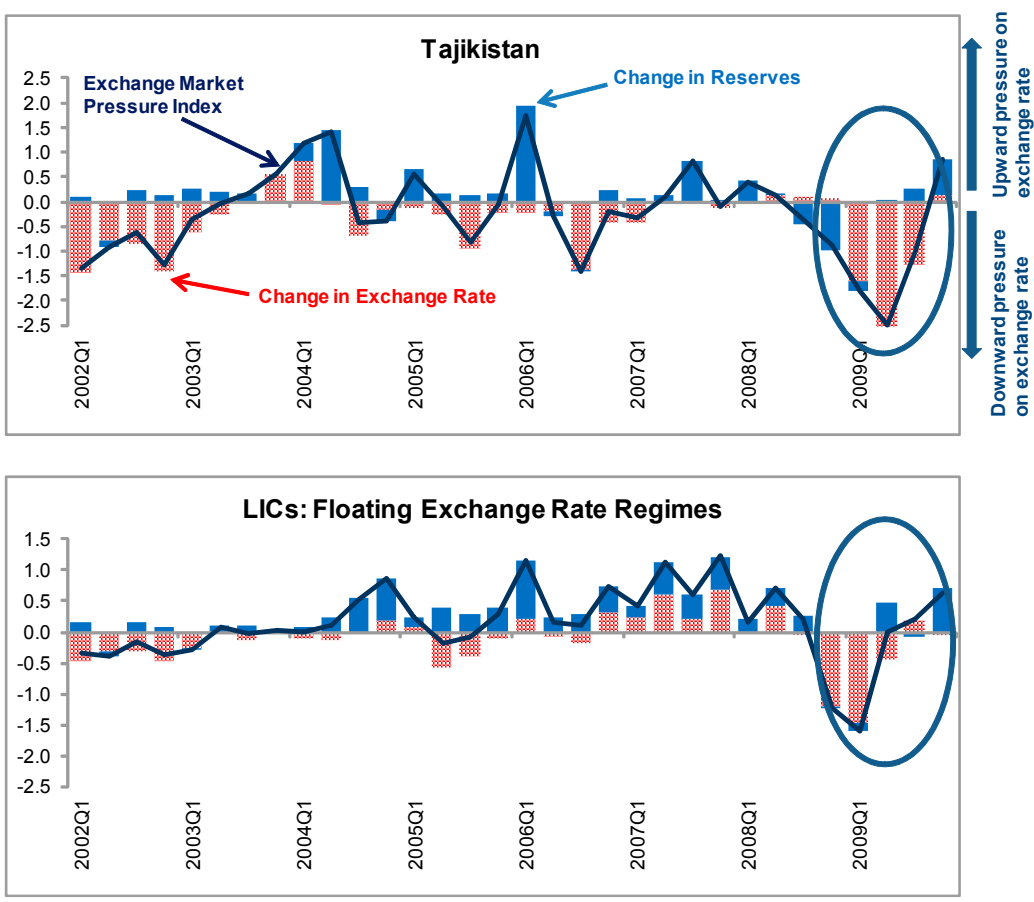

Note. The EMPI combines movements in the exchange rate and international reserves. Negative (positive) values suggest downward (upward) pressure on the exchange rate, to which countries could respond by either letting the exchange rate depreciate (appreciate) or by selling (accumulating) reserves. The in dex is the weighted average of quarterly changes in foreign reserves and quarterly changes in nominal bilateral exchange rates, using the inverseof their standard deviations as weights. Changes in foreign reserves are normalized on base money. 


\section{Box 2. Tajikistan: Financial Sector Developments}

The banking system continues to show signs of weakness despite a modest decline in classified assets. This mainly reflects the exposure of the two largest banks to the cotton and state enterprise sectors. Stress tests point to a degree of resilience at the system level, but capital positions should be strengthened, risk management and accounting practices improved, and dependence on liquidity support from the NBT eliminated.

From a systemic perspective, bank profitability is low, and classified loans remain a concern. After turning negative in mid-2010, commercial banks' returns on equity and assets improved modestly_registering 0.8 and 3.8 percent, respectively, in the fourth quarter. Total system capital has followed a similar pattern, contracting during the third quarter and recording a slight recovery late in the year. Both capital and profitability have benefitted from a reduction in classified assets and the associated decline in provisioning. Classified loans declined to 17.2 percent of total loans by the end of 2010 from a peak of 28 percent in the first quarter. However, almost all of this improvement reflects recent restructuring efforts at a few banks, including a reclassification of the terms related to a sizeable directed loan portfolio held by Agroinvest Bank (AIB).
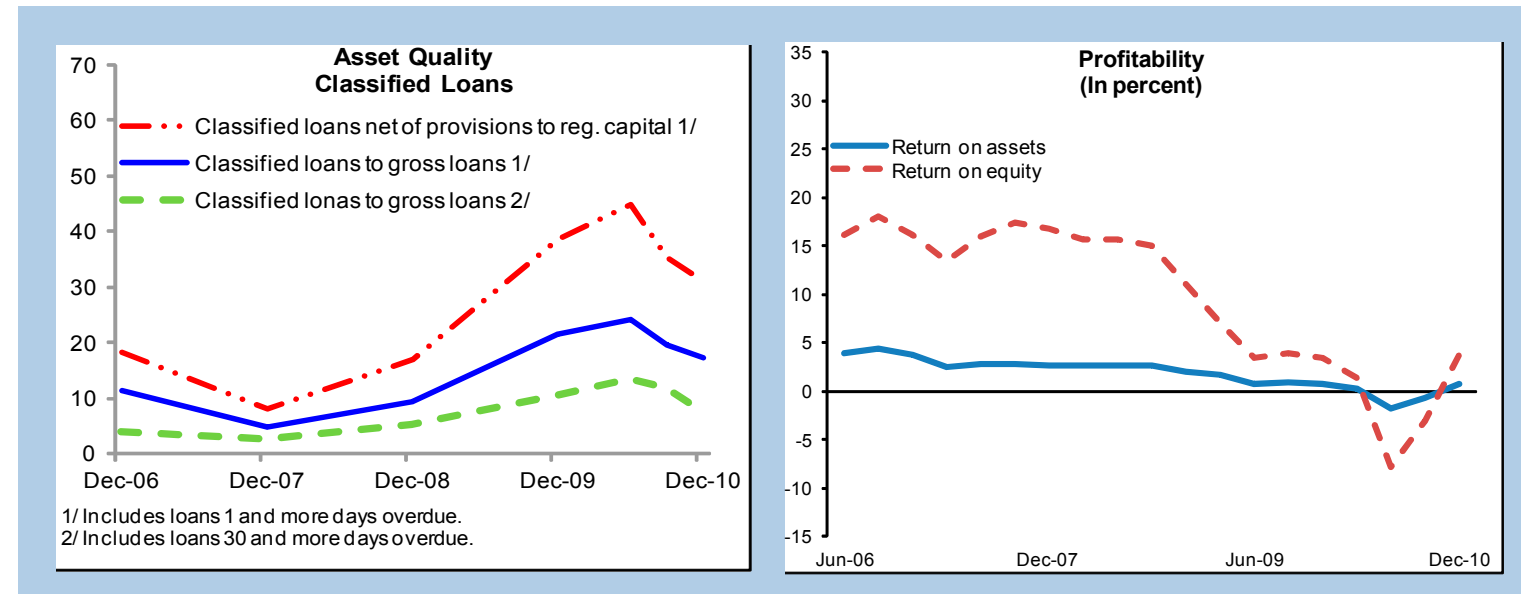

The weakness in the system's financial soundness measures is attributable largely to the deterioration of the balance sheets of the two largest banks. Orien Bank (OB) and AIB account for nearly 60 percent of system assets and hold the majority of classified loans, which dropped from 67 percent of total loans in September to 60 percent by end-2010. Despite this improvement, these banks' exposure to problematic sectors is significant and poses ongoing challenges to their capital positions. The recent write-back of provisioning has improved CARs for OB (adjusted for government cotton debt) and AIB to 20 percent each (from 19.3 and 13 percent previously), but this may only prove temporary given their loan concentration.

Banks have been increasingly dependent on NBT liquidity loans to meet their funding needs. This mitigates banks' incentives to enhance capital buffers, implement stricter risk management and accounting practices, and engage in interbank markets. Outstanding liquidity loans at end-January 2011 amounted to over SM 465 million, with OB and AIB accounting for the majority. While the banking system's liquid assets remain below pre-crisis levels, current borrowing appears inconsistent with historical liquidity needs, and reinforces balance sheet risks to both banks and the NBT.

The financial system remains vulnerable to future shocks. Stress tests indicate that credit risks to capital adequacy are non-negligible, particularly when large exposure loans migrate into doubtful categories. Under such assumptions, the system's CAR declines by 8.5 percent to 15 percent, while an increase in the deposit rate of 4 percent translates into a decline of 8 percent in the CAR. Liquidity risks do not appear to be significant, but a depreciation of the exchange rate would negatively affect system capital given heavy financial dollarization.

The NBT should undertake urgent steps to strengthen the financial sector and reduce its dependence on liquidity support. In particular, system capital requirements should be raised, collateral strictly enforced, governance frameworks enhanced, and the terms of liquidity support brought in line with market trends. In addition, T-bills issued to banks as part of the cotton debt resolution should be reissued on market terms. 


\section{MediuM-Term OUTLOOK}

9. The nascent recovery provides grounds for optimism, but significant challenges remain in the post-crisis environment. The economy remains relatively undiversified and dependent on external financial flows - especially remittances. High pre-crisis growth rates were enabled by large-scale emigration and an associated sixteen-fold increase in remittances as a share of GDP during 2001-08, which in turn fueled an increase in trade and services activity, as well as higher levels of construction. Significant investment in agriculture (including cotton) also contributed to high levels of economic growth, and may do so in the future, depending on continued progress in land reform and establishing sustainable mechanisms for agricultural financing.

10. On balance, future growth may be lower than during the boom years, but more sustainable, and will depend on a mix of policies to address existing vulnerabilities, ensure macroeconomic stability, and boost market orientation. The authorities' medium-term strategy is embodied in the National Development Strategy and the Poverty Reduction strategy (PRS) for 2010-12. The economic development pillar of the PRS (which complements the strategy for health, education, and food security) emphasizes (i) development of Tajikistan's comparative advantage in hydroelectricity production; (ii) agricultural diversification; and (iii) creating a more conducive environment for private sector activity and investment - including reforms in land and property rights, state enterprise management, removing regulatory barriers to trade and investment, and boosting financial intermediation and access to credit. Consistent with these objectives, public investment is expected to remain strong (albeit declining from recent peaks in line with a relatively conservative projection for external financing over the medium term as spending on Roghun tapers off) and private investment is projected to rise steadily.

\section{Tajikistan remains at a high level of debt distress under the joint Bank-Fund} Debt Sustainability Framework (see Appendix). While the level of external debt is not high by international comparison and domestic debt remains small, Tajikistan's low level of institutional capacity and vulnerability to external shocks translates into a larger potential for debt distress. However, notably, the projected prolonged breaches of debt sustainability thresholds under the baseline scenario and under stress tests do not incorporate remittances in the debt sustainability assessment. If remittances (currently in excess of 30 percent of GDP) were included in the analysis, Tajikistan's risk of debt distress would likely be lower.

\section{Policy Discussions}

12. Against this backdrop, the policy discussions focused on (i) the recent rise in inflation and the government's policy response; (ii) addressing vulnerabilities in the financial sector; and (iii) shifting to a post-crisis fiscal stance, while ensuring sufficient space for critical social and infrastructure spending. 


\section{A. Coping with Price Shocks}

13. Rising inflation is likely to be a central policy challenge in the near and medium term, particularly if the shock to food and fuel prices is sustained. Food imports make up about 20 percent of Tajikistan's total import bill (about 8 percent of GDP), and food and fuel together make up just over 60 percent of the CPI basket. The bulk of Tajikistan's wheat and flour come from Kazakhstan, but prices are sensitive to international commodity market fluctuations, and the price increase following Russia's export ban have been clearly visible in the food component of Tajikistan's CPI.

\section{The government's response to recent price shocks has been mainly through} administrative measures. In late 2010 and early 2011, the government imported and sold food products from strategic reserves in an effort to ensure adequate supply to the market and curb any speculative pressures. Government agencies (such as the Antimonopoly Agency) have been charged with monitoring prices in an attempt to curb any "artificial" rise in the prices of essential goods. The government has also sought relief from the recent increase in fuel export duties imposed by Russia, and is considering measures to foster agricultural diversification and ensure a robust supply response to the shift in relative prices. ${ }^{6}$ The decision to restrict the increase in public sector wages and salaries, while motivated primarily by budget concerns, is also likely to have mitigated the risk of second round inflation effects.

\section{Monetary policy in this context will need to find a balance between supporting} the recovery and minimizing second round effects of the food and fuel price increases. While core inflation has been subdued, headline inflation increased to 12 percent in February 2011 , adding to the risks posed by the pickup in money growth. The recent 75 basis point increase in the policy rate to 9 percent is welcome, but in the absence of an active interbank market the interest rate channel of monetary policy remains relatively weak. More stringent terms on liquidity loans ${ }^{7}$ should provide greater traction for containing reserve money growth to levels consistent with the objective of mitigating upward pressure on core inflation. In particular, increasing the interest rate for liquidity lending to prevailing market levels and restricting the use of this facility to emergency purposes should help to reduce banks' dependence on the NBT, and contain reserve money.

16. Over the medium term, a framework for direct support to the poor in the event of shocks is needed. Cash transfer mechanisms now in place apply only to (i) selected

\footnotetext{
${ }^{6}$ The World Bank is assisting Tajikistan with additional financing for the emergency food security response project to increase domestic food production and improve the ability of poor households to deal with seed shortages because of poor crops. This includes a new temporary revolving fund for fertilizer imports to help private commercial farmers cope with the collapse of the existing fertilizer supply chain.

${ }^{7}$ The interest rate on liquidity loans was raised at end-March 2011 from about 9 percent to 21 percent and 22 percent for foreign exchange and somoni-based loans, respectively, consistent with prevailing lending rates.
} 
consumers of electricity and gas; and (ii) low income households to encourage school enrollment. The amounts involved in these two schemes are small, and neither has the potential for rapid scaling-up. The World Bank is engaged in preparing a project to help develop a more effective system of social assistance. A pilot of consolidated social assistance is underway in two local districts to test a proxy-means-based methodology to identify beneficiaries. However, given the time necessary to establish a database of beneficiaries and set up the infrastructure for transfers, it will likely be two-three years before a system is in place.

\section{B. Financial Sector-Vulnerabilities and Policies}

\section{Directed lending, regulatory forbearance, and exposure to weak or volatile} sectors have left a legacy of low banking sector profitability and a large stock of classified loans. The small size of the financial sector and limited financial intermediation suggest the systemic risk of a bank failure to economic activity is relatively low. The narrow composition of deposits also suggests that bank runs in the classic sense are unlikely, and that the impact of a bank failure would not fall primarily on the poor. ${ }^{8}$ However, standardized stress tests also indicate vulnerability of capital adequacy to a range of shocks. Given the limited capacity of the deposit insurance scheme, and the net-negative position of the NBT, absorbing potential financial system losses could fall to the budget. Further, low levels of financial intermediation are a drag on prospects for future economic growth.

Tajikistan: Cross Country Comparison of Financial Intermediation

\begin{tabular}{|c|c|c|c|c|}
\hline & Broad Money & $\begin{array}{c}\text { Credit to the } \\
\text { Private Sector }\end{array}$ & Deposits & $\begin{array}{l}\text { Banking } \\
\text { Assets* }\end{array}$ \\
\hline \multicolumn{5}{|c|}{ (in percent of GDP) } \\
\hline Tajikistan & 18 & 15 & 12 & 24 \\
\hline Armenia & 27 & 26 & 17 & 48 \\
\hline Azerbaijan & 24 & 18 & 12 & 44 \\
\hline Georgia & 30 & 33 & 24 & 57 \\
\hline Kazakhstan & 45 & 46 & 39 & 81 \\
\hline Kyrgyz Republic & 31 & 13 & 13 & 31 \\
\hline Uzbekistan & 20 & 17 & 16 & 52 \\
\hline Average & 27.9 & 24.0 & 19.0 & 48.1 \\
\hline
\end{tabular}

\footnotetext{
${ }^{8}$ A substantial portion of bank deposits come from state or quasi-state enterprises. Remaining private deposits are relatively few in number.
} 
18. The authorities recognize the need for financial sector reform. They pointed out that financial sector indicators had improved steadily over the year, and that (due largely to high prices and investor interest) no additional bank financing for the cotton sector was needed for 2010. They agreed on the need for a reform strategy that would address, in sequence: (i) regulation; (ii) accounting; (iii) revaluation of asset positions; and (iv) on the basis of the preceding steps, a reassessment of banks' position relative to prudential criteria, including capital adequacy. Work in this area has already begun, based on a vulnerability assessment conducted by the World Bank, and will be further facilitated by donor-funded strategic advisors. In line with a structural benchmark for end-March 2011, banks not in compliance with established prudential criteria have also submitted time-bound actions plans to become fully compliant with these standards. A role for Fund technical assistance may be needed as the work progresses. A sustainable mechanism for agricultural financing will also be needed to ensure that the banking system and the state budget are protected going forward (see Box 6).

\section{Maintaining Fiscal and Debt Sustainability}

\section{Counter-cyclical fiscal policies in 2009-10 allowed for tax cuts, additional} expenditures, and an expansion of the fiscal deficit beyond historical norms. The overall deficit, including the foreign-financed PIP, averaged nearly 5 percent per year during 2008-10, putting external debt on a rising trend. While the narrower deficit, excluding the foreign financed PIP, has not been large by international comparison, it poses a potential risk going forward given (i) the lack of international market access and the near absence of a domestic debt market; (ii) a limited cushion of government deposits at the NBT; and (iii) an increase in recurrent expenditures (partly associated with social spending), without similar gains in tax revenue (see Boxes 3 and 4). In addition, high external debt (and a high risk of debt distress under the DSA framework), as well as potential contingent liabilities in state enterprises (see Box 5) and the financial sector ${ }^{9}$ suggest the need for careful fiscal management, rebuilding buffers, and leaving room for maneuver in the event of negative shocks. Particular emphasis is needed on improving the efficiency of tax collection and a review of tax policy.

20. Fiscal consolidation will therefore be needed over the medium term. The fiscal stance envisioned for 2011 (a deficit of 1 percent of GDP) seeks to balance support for

\footnotetext{
${ }^{9}$ A proper evaluation of potential fiscal liabilities from the financial sector must rest first upon a rigorous and uniform accounting of problem assets and provisioning - key elements of the financial sector reform plan slated for June 2011 (benchmark under the ECF). Depending on a range of factors and the nature of remedial actions, the fiscal cost of bank restructuring could be minimal. However, to give a sense of potential magnitude, the deficiency in regulatory capital from a combined shock under standard stress tests amounts to about 0.5 percent of GDP, whereas a blanket guarantee on deposits of the two largest banks would be in the range of 5 percent of GDP.
} 
anti-inflationary monetary policies and addressing social pressures, including from higher food prices. Looking ahead, however, some consolidation (at least to a balanced budget, excluding the PIP) will be needed to meet both external and internal resource constraints. In the absence of additional budget support from donors, continuing deficits of up to 1 percent of GDP , as implied under the government's medium-term expenditure framework (MTEF) may not be feasible given a declining buffer of government deposits in the banking system and a very shallow domestic debt market (see Boxes 3 and 4). At the same time, incurring additional external debt to finance government spending (even if available) would add further pressure to debt dynamics. Tajikistan can ill afford such debt given its already high risk of debt distress.

\section{The authorities accepted the need for prudent fiscal management, as well as the} need to rebuild some fiscal buffers. But they also highlighted pressing social expenditure needs (a point also emphasized by donors), and the comparatively low level of spending in this area compared with other countries in the region. They also emphasized investment spending on Tajikistan's relatively underdeveloped physical infrastructure (particularly hydroelectricity, which is a key element under the poverty reduction strategy) as central to ensuring levels of economic growth sufficient to address poverty and unemployment. ${ }^{10}$ Staff highlighted the need to raise tax revenue to its full potential and the desirability of additional grant financing to create room for higher spending in these priority areas.

\footnotetext{
${ }^{10}$ Tajikistan's Poverty Reduction Strategy (PRS) identifies energy development as a key priority for social and economic development. The authorities expect that harnessing Tajikistan's hydropower potential will provide uninterrupted supply of electricity, provide foreign exchange, and encourage investment in energy-intensive industries. The Joint Staff Assessment Note (JSAN), highlighted the need for realistic priorities across different objectives and to identify additional financing sources for the ambitious program. At that time, the PRS had a cumulative financing gap of US\$8 billion — likely to increase further once the Roghun project is fully costed.
} 


\section{Box 3. Tajikistan: Medium-Term Fiscal Sustainability}

With the economy now recovering, Tajikistan needs to moderate or eliminate budget deficits to maintain fiscal sustainability and rebuild buffers. A countercyclical fiscal response to the global crisis starting in 2009 led to budget deficits and a drawdown of government deposits accumulated in previous surplus years. Particularly in light of expected increases in external debt service, fiscal consolidation will be required to maintain debt sustainability going forward.

The government's Medium-Term Expenditure Framework (MTEF) for 2011-13 has yet to reflect constraints imposed by the need to maintain fiscal sustainability. A sustainable fiscal framework for Tajikistan needs to satisfy two constraints - the first imposed by external debt sustainability (see DSA), and the second by a realistic ceiling on domestic financing. Under staff's conservative revenue and grant projections, the authorities' MTEF-based expenditure levels could result in fiscal gaps (as much as 1 percent of GDP by 2013), which would be difficult to fill from domestic sources given (i) limited appetite for domestic debt; and (ii) the likely depletion of government deposits in the banking system by 2013. External financing to fill these gaps, even if available, would bring public debt above the targeted ceiling of 40 percent of GDP, and extend significantly the breach of debt sustainability thresholds over the long term in the event of most adverse shocks.

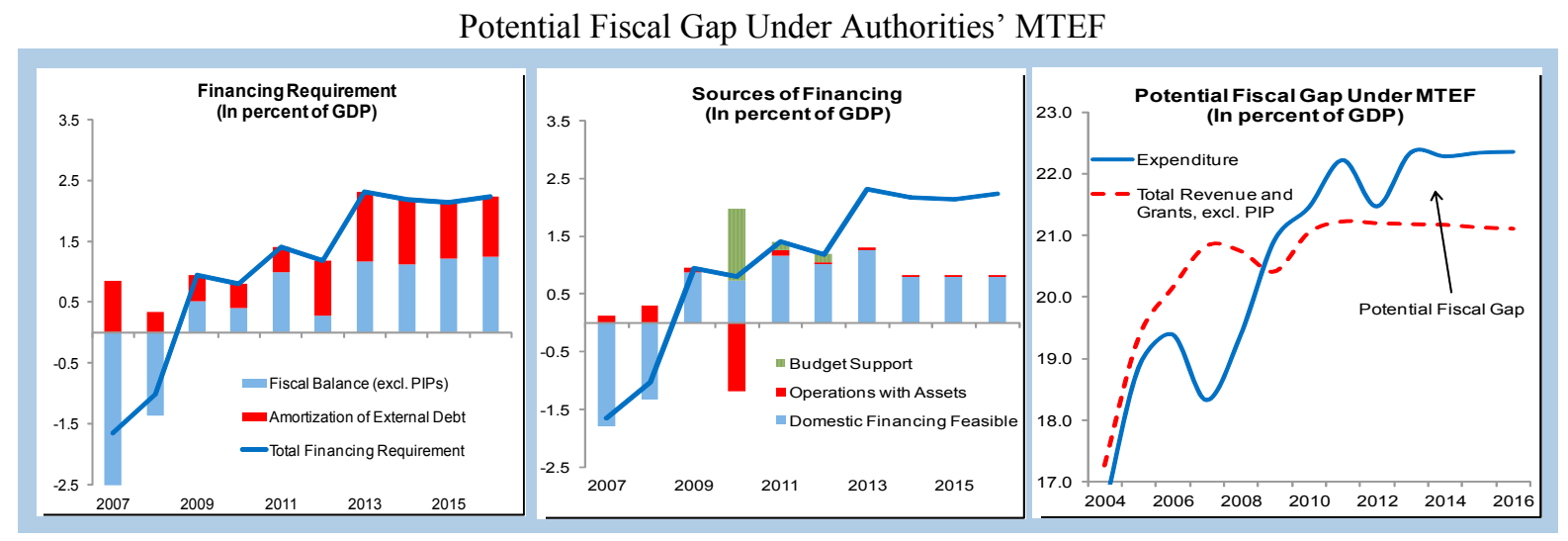

Revenue and expenditure measures together with financial market development will be needed for medium-term sustainability. On the revenue side the staff's adjustment scenario targets an increase in the efficiency of tax collection, a decrease in tax exemptions, and an overhaul of tax policy (with IMF technical assistance) - leading conservatively to a revenue increase of perhaps 0.5 to 1 percentage point of GDP over the medium term. Remaining adjustment should come from expenditure compression after taking into account the potential for increases in domestic financing. Staff estimates the capacity of the banking system to absorb new government debt to be in the range of $0.5-0.8$ percent of GDP per year in 2011-16. Allowing for substantial investment spending, a sustainable fiscal path would imply on average a balanced budget in the medium term.

Notably, the proposed fiscal path (while sustainable in a normative scenario) leaves little room for dealing either with new external shocks or quasi-fiscal risks from the state enterprise and financial sectors. A more aggressive path for revenue improvement, a less ambitious (but hopefully well targeted) path for investment spending, or additional grant resources from donors would be necessary to establish a cushion for such shocks. In this context, the path proposed above is a minimal adjustment, and a more aggressive approach consistent with rebuilding fiscal buffers would entail a return to small fiscal surpluses over the medium term. 


\section{Box 4. Tajikistan: Financial Market Developments}

Financial markets in Tajikistan are embryonic. Liquidity in all markets (money, bond, stock, and foreign exchange) is low, secondary markets have yet to emerge, and interbank lending is minimal. To deepen financial markets, the issuance of T-bills should be properly integrated in the process of public debt management. To help create an active interbank market, the structural weaknesses in commercial banks should be addressed and the NBT should only lend to banks for emergency liquidity reasons.

The money market is the only active securities market in Tajikistan. NBT Depository Certificates (CDs) and government T-bills are the only instruments. CDs are issued twice a week-with 14 and 28 day maturities - and monthly with a 56 day maturity. Total issuance is usually small-about SM 153 million ( 0.6 percent of GDP) and mainly for monetary management. With IMF technical assistance, T-bill auctions were started in 2009. Some SM 53 million were issued in 2010 - all with a maturity of 91 days and an average interest rate of 7 percent. The auction process is improving, and bid-to-cover ratios have risen steadily. However, the issuance of T-bills has yet to be integrated with budget financing needs. The Ministry of Finance also issued bonds to commercial banks as part of the cotton debt resolution, but on nonmarket terms (8 year maturity and 2 percent interest). The legal framework for a stock market exists and the stock exchange resides theoretically in the NBT, but no active trading takes place.
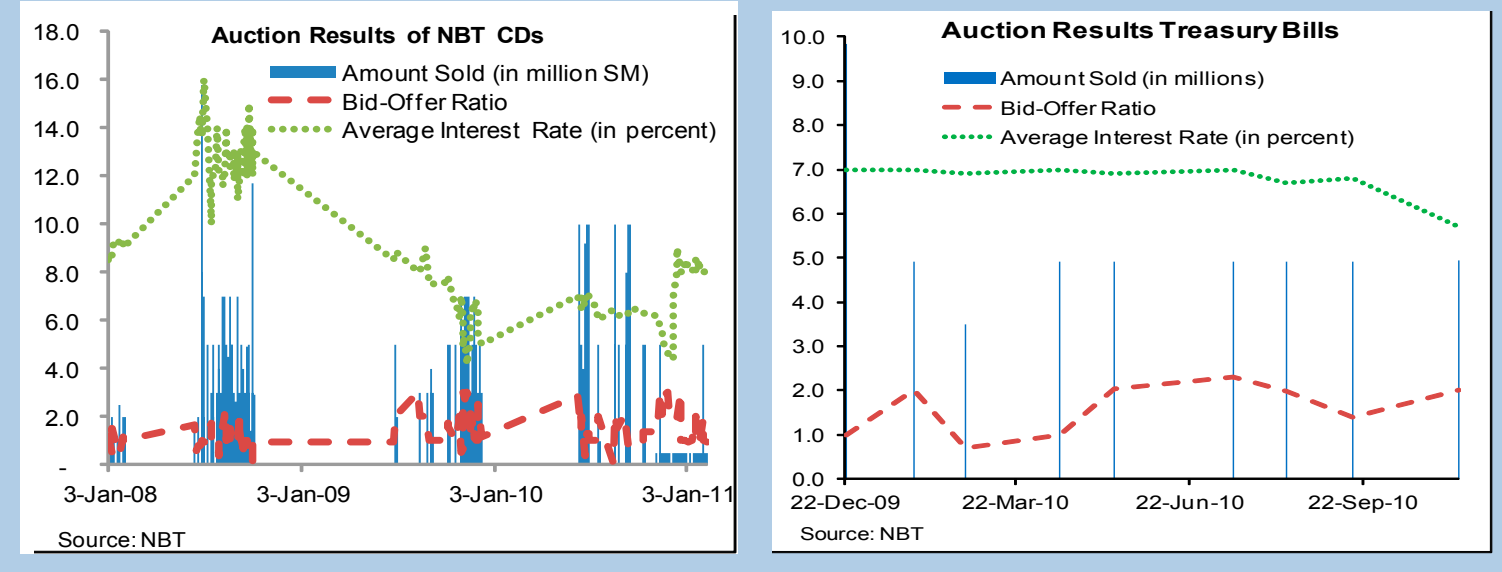

Trading in currency markets takes place mainly in U.S. dollar, Russian Ruble, and Euro. The NBT provides foreign exchange to the commercial banks through spot trading and liquidity loans in dollars and Rubles upon availability. Currencies are also traded in the interbank market and by foreign exchange traders on the street market. The highest volume of trade occurs in U.S. dollars (\$6.8 million in 2010) as the economy remains highly dollarized. Second comes the Russian Ruble, reflecting the main source of remittances. The NBT restricts banks' open currency positions to a small proportion of their capital such that larger transactions often cannot be accommodated by market participants.

The efficiency of financial markets in Tajikistan could be improved by several measures. A proper integration of T-bill auctions in the process of public debt management and budget financing would increase the reliability of the auctions, their liquidity, and size. To avoid fragmenting the market, higher demand would be an important precondition for lengthening maturities and development of a proper yield curve. A liquid primary T-bill market could be a catalyst for secondary market trading and, when used as collateral, for a more active interbank market. The interbank market has also been constrained by a lack of confidence in the repayment capabilities of counterparties. A stronger, more effective supervisory role by the NBT and actions to address underlying vulnerabilities in commercial banks is needed to address this constraint. Additionally, the banking system needs to be weaned from the ample and relatively inexpensive liquidity available through the NBT. Beyond the increase in liquidity loan rates, future measures could potentially include introduction of a standing overnight facility for emergency liquidity. 


\section{Program Review and Policies for 2011}

22. Performance under the program has generally been good. All but one of the quantitative performance criteria for end-December 2010 were met. The exception was with respect to the continuous criterion on accumulation of new external payment arrears.

23. In the context of the discussions on the fourth review, staff received data indicating that arrears were accumulated in 2010 on two external loans with government guarantees.

- In the first case, external payment arrears accumulated on two scheduled payments from a Tajik textile company to a German bank of Euro 86,685 and Euro 83,272 in January and July 2010, respectively, and reached a maximum of Euro 103,032 (equivalent to US\$148,428 at program exchange rates) during the course of the year. All payment arrears were cleared by end-August 2010, and penalty interest was cleared by end-December 2010 .

- In the second case, the City of Dushanbe entered into a loan agreement in July 2008 with the European Bank for Reconstruction and Development (EBRD), guaranteed by the central government. On October 26, 2010, the EBRD presented the City of Dushanbe with the Billing Advice for US\$43,426 which consisted of US\$216 in loan interest and US\$43,210 in a commitment charge, payable on November 15, 2010. The authorities have indicated that the City of Dushanbe paid the amount of $\$ 43,426$ on January 17,2011 - two months after the date due.

24. Following interdepartmental consultations, staff has concluded that the arrears are so small as to be trivial, with no material impact on debt sustainability. As such, staff supports the granting of a waiver for the nonobservance of the continuous performance criterion on non-accumulation of external payments arrears. Importantly, the discovery of the arrears has prompted a range of remedial actions by the authorities. To prevent recurrence of new arrears on the textile company loan, the Ministry of Finance is drafting a supplementary guarantee agreement introducing a penalty interest that would be paid to the government if the loan falls in arrears. The government has also requested a Debt Management Performance Assessment (DEMPA) from the World Bank, and has reaffirmed that issuance of such guarantees will continue to be restricted. ${ }^{1112}$

\footnotetext{
${ }^{11}$ Government guarantees on external loans are limited, and in recent years have been extended only to loans from the EBRD. At end-2010, there were only nine such guarantees in place covering seven EBRD loans, one bilateral loan from Russia, and the loan to the textile company (together covering some US\$23.4 million). Except for the textile company loan, the borrowers are all public entities. And the textile company was a public enterprise when the loan was made in 1997.
} 


\section{Two of the indicative targets (IT) under the program were also missed:}

- Social spending. The authorities maintain that budgetary targets on health and education spending were met. With respect to the IT under the program, however, spending was less than targeted due to a decision to limit the increase in public sector wages and salaries, and a decision not to fill a number of vacancies. The mission emphasized the importance of meeting social spending targets - particularly given the relatively low (on a cross country basis) level of spending in this area, and noted that there was sufficient room under the program to meet the target but that priority had been given to capital spending.

- NBT liquidity lending. While a significant portion of new liquidity lending was related to the import of strategic food and fuel products, the rapid increase and impact on reserve money posed the risk of additional pressures on inflation, the exchange rate, and the NBT balance sheet. ${ }^{13}$ To address these risks, staff and the authorities reached understandings on the following steps: (i) resetting the indicative targets for 2011 in line with the revised macroeconomic framework and with a view to substantially reducing NBT liquidity loans; (ii) restructuring the IT for liquidity support from an end-quarter basis to a three-month average to address the issue of intra-test date volatility; and (iii) changing the terms of these loans to reduce their attractiveness and better assure that they are used for short-term liquidity management.

26. Changes to the macroeconomic framework require one proposed revision to the performance criterion for net domestic assets for end-June 2011 and end-December 2011. The monetary framework was adjusted to accommodate a higher level of real GDP growth and inflation in 2010 and 2011. In this context, the authorities are requesting an upward revision to the target for net domestic assets for end-June 2011 and end-December 2011. Even with this upward revision, monetary policy remains moderately restrictive and consistent with the objective of mitigating second-round effects from the ongoing food and fuel shock.

\footnotetext{
${ }^{12}$ Recognizing that capacity constraints have also contributed to the occurrence of misreporting, the staff proposes to amend the Technical Memorandum of Understanding (TMU) to add a grace period of 30 days to the definition of external payments arrears.

${ }^{13}$ The NBT continues to be in a net negative capital position. A recapitalization strategy (formulated with IMF TA) has suffered delays, but progress is being made. In August 2010, a presidential order was issued requiring cotton investors to repay their obligations. The government also agreed, as part of the 2011 budget, to inject SM 200 million into the NBT. The NBT also converted an outstanding Ministry of Finance deposit from the Multilateral Debt Relief Initiative to equity, and has reinstated two thirds of the Kredit Invest cotton producer loans (written off in 2009). As a result, NBT's level of negative equity fell from about SM 2.6 billion at end-2009 to SM 1.9 billion by end-2010.
} 
27. Structural measures for the fourth review were met with slight delays. Audited NBT financial statements through December 2009 were published on the NBT's website in September 2010, as envisioned. A revised NBT law and draft bankruptcy law for credit institutions were submitted to parliament in the first week of January 2011 (just after the end-December 2010 deadline). Importantly, the Roghun OJSC has continued to publish on the Ministry of Finance website quarterly reports on sources and uses of funds, along with other operational data. Plans are also proceeding for a general shareholders' meeting in the first half of 2011 (a commitment under the MEFP).

28. The attached LOI and TMU update the government's policies and commitments for 2011. The authorities have encountered technical difficulties in meeting one benchmark (publication of an audit of Roghun OJSC, slated for end-February 2011), and are requesting to have this shifted to end-June $2011 .{ }^{14}$ Staff and the authorities came to an understanding on publication of audited financial statements for Talco Management by end-June 2011, which is significant step forward in transparency. Understandings were also reached on a structural benchmark for NBT Board approval by end-June 2011 of a reform strategy to maintain financial sector stability. This should serve as an anchor for addressing vulnerabilities and transparency issues in the financial sector as well as a framework for structuring technical assistance from the IMF and other sources. In the revised TMU, a new program exchange rate (based on the end-2010 rate) is being proposed, as well as a new definition for the indicative target on NBT liquidity loans, and (recognizing capacity constraints) a grace period in the definition of external payments arrears.

\section{Risks to the program stem from the potential for new exogenous shocks and} from the many challenges involved in the transition to a more market based economy. As a landlocked economy with a heavy dependence on food and fuel imports, a reliance on inward remittances, and a relatively narrow export base, Tajikistan's external position and growth prospects are vulnerable to shocks from different directions. Vulnerabilities in the financial and state enterprise sectors also remain, and could represent a quasi-fiscal liability should efforts to reform these institutions be delayed or watered-down. Critical in this regard will be the commitment from the government to refrain from directed lending and to make room for supervisory authorities to take corrective actions, when necessary.

\section{Staff Appraisal}

30. The economic recovery in Tajikistan is taking hold, and the medium-term outlook has promise, but challenges remain. Facilitated by a regional economic rebound, rising aluminum prices, agricultural diversification, favorable climatic conditions, and counter-cyclical fiscal policies, economic growth is rising. A return to the pre-crisis boom

\footnotetext{
${ }^{14}$ An audit firm has been selected, but before review of the financial statements can take place, an audit of work in progress (fixed assets) needs to be conducted. This process is expected to take several months.
} 
years is unlikely, but there is room for optimism that Tajikistan can generate sufficient rates of economic growth to make progress in reducing widespread poverty and unemployment. Careful macroeconomic management, rebuilding fiscal buffers, a comprehensive effort to address financial sector vulnerabilities, and a commitment to market-oriented reforms, including in the areas of governance and transparency, will be key.

\section{The shift to a post-crisis environment suggests the need for a fresh look at} medium-term fiscal objectives. The government's medium-term fiscal policy is appropriately anchored in the National Development Strategy and the Poverty Reduction Strategy, and the fiscal framework for 2011 remains broadly appropriate. However, as the crisis recedes, consolidation will be needed to ensure medium-term fiscal and debt sustainability. Particularly in light of expected increases in external debt service, a steady reduction of deficits will be required to maintain debt sustainability going forward. The staff recommends a combination of (i) continued progress on improving tax administration; (ii) a review of tax policy with a view to simplifying the tax regime, expanding the tax base, and facilitating an increase in tax revenue; (iii) continued development of the domestic debt market; and (iv) maintaining a careful balance between current and capital expenditures in order to simultaneously meet resource constraints while meeting social and developmental objectives outlined in the poverty reduction strategy.

\section{The staff recognizes the potential impact of recent inflation on the poor. It}

supports the authorities' proactive approach in trying to mitigate this impact, but emphasized the need to ensure transparency and avoid long-term fiscal costs. In the absence of adequate social safety nets, the authorities had little alternative but to resort to temporary administrative measures. Staff considers, however, that further operations to procure food and fuel for strategic reserves should be carried out as a fiscal operation rather than through the banking system, and that blanket subsidies should be avoided. Looking ahead, a more effective means of providing direct and targeted assistance to the poor is needed and the authorities are encouraged to cooperate closely with the World Bank to develop such a system.

33. Monetary policy needs to focus on containing inflation. Liquidity lending has surged to levels beyond what would be expected for banks' emergency liquidity needs. The associated excessive growth in reserve money could potentially put upward pressure on core inflation and downward pressure on the somoni if maintained over the course of the year. Substantial short-term depreciation pressures would be a particular concern for financial sector stability, given the high degree of dollarization. The risk of nonrepayment to the NBT is also non-negligible. Staff urges a reduction of liquidity lending in line with a path for net domestic assets and reserve money consistent with macroeconomic stability.

\section{Exchange rate policy needs to take into account the potential for fundamental} shifts in the terms of trade. The continued rise in food and fuel prices, coupled with a sharp projected downturn in cotton prices suggest the somoni may be overvalued on a 
medium-term perspective. As such, staff urges the authorities to take a flexible approach to exchange rate management. While intervention may be necessary to smooth excess volatility, the NBT should not resist fundamental shifts in the supply and demand for foreign exchange, but allow the somoni to move in line with these forces to facilitate external adjustment and protect the limited stock of foreign exchange reserves.

\section{A comprehensive and well-sequenced effort is needed to address financial sector} vulnerabilities. Failure to address structural weaknesses in the financial system could evolve into fiscal liabilities, particularly in the event of external shocks. Key actions should include: (i) an end to directed lending; (ii) a uniform classification of NPLs, together with tighter standards on reclassification; (iii) a requirement for banks to fully provision for the uncollateralized portion of NPLs; and (iv) a reevaluation of banks' capital adequacy and a requirement for capital infusions to ensure banks meet minimum capital adequacy requirements. From the government side, a reissuance of government bonds placed with the banks to compensate for cotton loans at market rates would be an important near-term step to improving banks' balance sheets and easing liquidity constraints.

\section{A self-sustaining mechanism for agricultural financing should be a central} objective. Considerable progress has been made in this area in recent years through the freedom to farm act, and the establishment of such initiatives as the Tajikistan Agricultural Financing Framework. It is critical that this work continue to prevent future recourse to the NBT or directed lending by the banking system to meet agricultural financing needs once the current boom in commodity prices ends. Should such a financing gap appear in the future, direct fiscal support (subject to the competing pressures on the budget and the transparency that accompanies such spending) would be a preferable course of action.

\section{Structural reforms should continue to target governance and transparency, but} also seek to facilitate market orientation. The progress made under the program with respect to transparency of state enterprises and government operations is laudable. The continued efforts to monitor the operations of SOEs through the Ministry of Finance are welcome, as is publication of financial information by Roghun OJSC. Looking ahead, staff emphasizes the potential benefits of an overhaul of the tax regime - both from the point of view of boosting revenue, but also to create a more open business environment. The latter will be particularly important for boosting economic prospects and job creation. On data provision and transparency, the staff welcomes the efforts to produce macroeconomic and financial data more regularly, and to publish these data on government agency websites. However, staff encourages the authorities to enhance Tajikistan's AML/CFT framework, notably by implementing the recommendations made during the Eurasian group 2008 mutual evaluation.

38. Policies under the program remain broadly on track. All quantitative performance criteria for end-2010 were met, with the exception of the continuous performance criterion on non-accumulation of external payments arrears. The accumulation of external arrears was 
unfortunate, but (i) was so small as to be trivial, with no material impact on program performance; (ii) resolved in a short period; and (iii) accompanied by credible corrective actions. In this regard, staff supports the authorities' request for a waiver for nonobservance of the continuous performance criterion on the non-accumulation of external payments arrears.

39. The two missed program indicative targets are a concern. The lower-thanprojected level of social spending relative to the program indicative target is regrettable, particularly given that there was over-performance with respect to the budget deficit target. Staff urges the authorities to maintain the emphasis on badly needed social spending, particularly in light of the potential impact of recent inflation on the poor. With respect to the missed indicative target on liquidity lending by the NBT, staff urges the authorities to observe the revised path for the remainder of the year, so as to alleviate potential upward pressure on prices and downward pressure on the somoni, and to protect the NBT balance sheet.

40. As overall performance under the program has been good, staff supports the authorities' request for completion of the fourth review under the ECF arrangement and the fifth disbursement. In this context, it also supports the authorities' request for modification of end-June 2011 and end-December 2011 performance criterion on net domestic assets; the modification of the definition of the indicative target on NBT liquidity loans; the use of a new program exchange rate; and introduction of a grace period in the definition of external payments arrears..

41. It is proposed that the next Article IV consultation be held in accordance with Decision No. 14747-(10/96), adopted on September 28, 2010 on consultation cycles. 


\section{Box 5. Tajikistan: State Enterprise Sector and the Problem of Arrears}

Arrears are a pervasive problem in Tajikistan. Key areas of the economy remain dominated by SOEs operating under soft budget constraints. Inter-enterprise and tax arrears are widespread, affecting profitability and engendering weak fiscal discipline. As of October 2010, the largest SOEs had SM 2.6 billion on accounts payable and SM 1.7 on accounts receivable, up from SM 2.2 billion and SM 1.6 billion in 2009, respectively. SOEs with the biggest overdue payables are Tajik Aluminum Company (Talco), Tajiktransgaz (gas supplier), Barki Tajik (the electricity company), and Tajik Rail. Tax arrears by state firms have also increased, amounting to almost 700 million or about 3 percent of GDP in 2010.

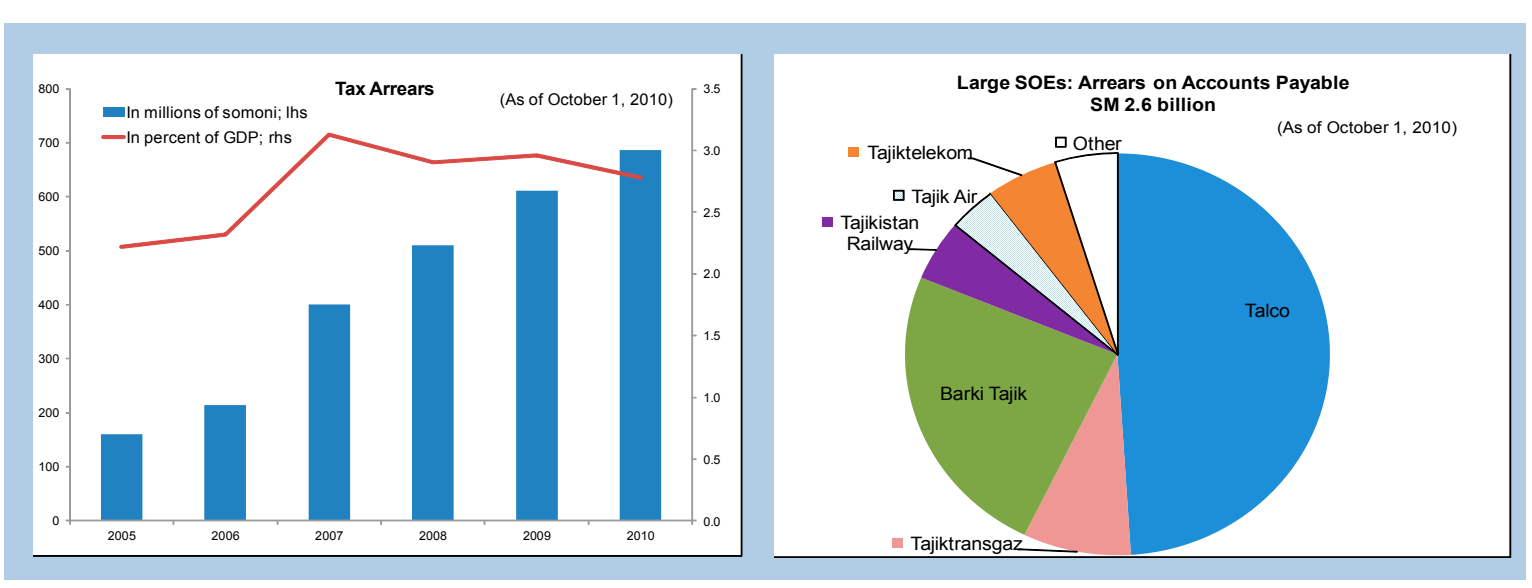

Large SOEs are responsible for almost half of tax arrears. Barki Tajik is the largest source, holding about 43 percent of all tax arrears, and reflecting in part inter-enterprise and other arrears on electricity services. These arrears persist despite periodic settlements with the government (the latest settlement in 2009 resulted in a decline of its tax obligations by roughly a quarter, or SM100 million). Barki Tajik also owes SM 627 million on accounts payables (claims on Barki Tajik, excluding tax arrears), and has large amounts on overdue accounts receivable (unpaid electrical bills and other claims on individuals and entities). Inability by the energy monopoly to collect payments for their services effectively and widespread government interventions seriously undermine its long-term financial viability.

Tolerance of arrears by the government and inability to enforce legal actions against noncompliant agents aggravate the problem. Government nonpayments, or delayed payments, create an incentive for other economic agents to follow suit. For example, arrears outside the budget are tolerated to compensate for budgetary arrears (like wages and salaries). At the same time, the government's ability to monitor arrears, and thus, prevent them is limited by the absence of a formal system to monitor arrears. An additional contributing factor is ineffective bankruptcy and judicial procedures, which make it difficult to enforce legal actions against noncompliant agents.

Resolution of the arrears problem will require wide-ranging actions to improve financial discipline. These include restructuring of SOEs to put them on the path of financial viability and subjecting them to hard budget constraints. To that end, the government has approved restructuring of Barki Tajik which will be undertaken with donor assistance in stages through 2015, and which among other things, involves breaking down the company into three entities with separation of power generation, transmission, and distribution. The SOE monitoring unit housed in the Ministry of Finance continues to build capacity in its role overseeing the operations of key SOEs and ensuring transparency. Completion of a fiscal risk assessment as part of the 2012 budget (a benchmark under the ECF arrangement) will also be a key step in transparency and sound public financial management. Supporting reform of the legislative and court system will also be required to more effectively regulate inter-enterprise financial relationships and boost enforcement of collection efforts. 


\section{Box 6. Tajikistan: Financing the Agricultural Sector}

Agricultural financing — particularly for cotton—has been a difficult issue in Tajikistan. While current high prices for cotton have led to sufficient financing from private investors, past years have required NBT and commercial bank involvement - contributing to the NBT's net negative capital position, and the rise in banks' classified or nonperforming assets. Looking forward, it is crucial to develop a sound market-based system, which grants farmers access to credit while at the same time protecting financial system stability.

While it accounts for a relatively small share of output, cotton production has dominated agricultural policy and credit resources. This concentration reflects an emphasis on cotton as an export good. Recent reforms such as the "Freedom to Farm Act" are leading to crop rotation and diversification into such value added products as fruit and vegetables. But cotton will likely continue to play a major role as its production is water and labor intensive (Tajikistan has generally been water abundant, and around 75 percent of the population is living in rural areas), related infrastructure is already in place, and perishability is low.

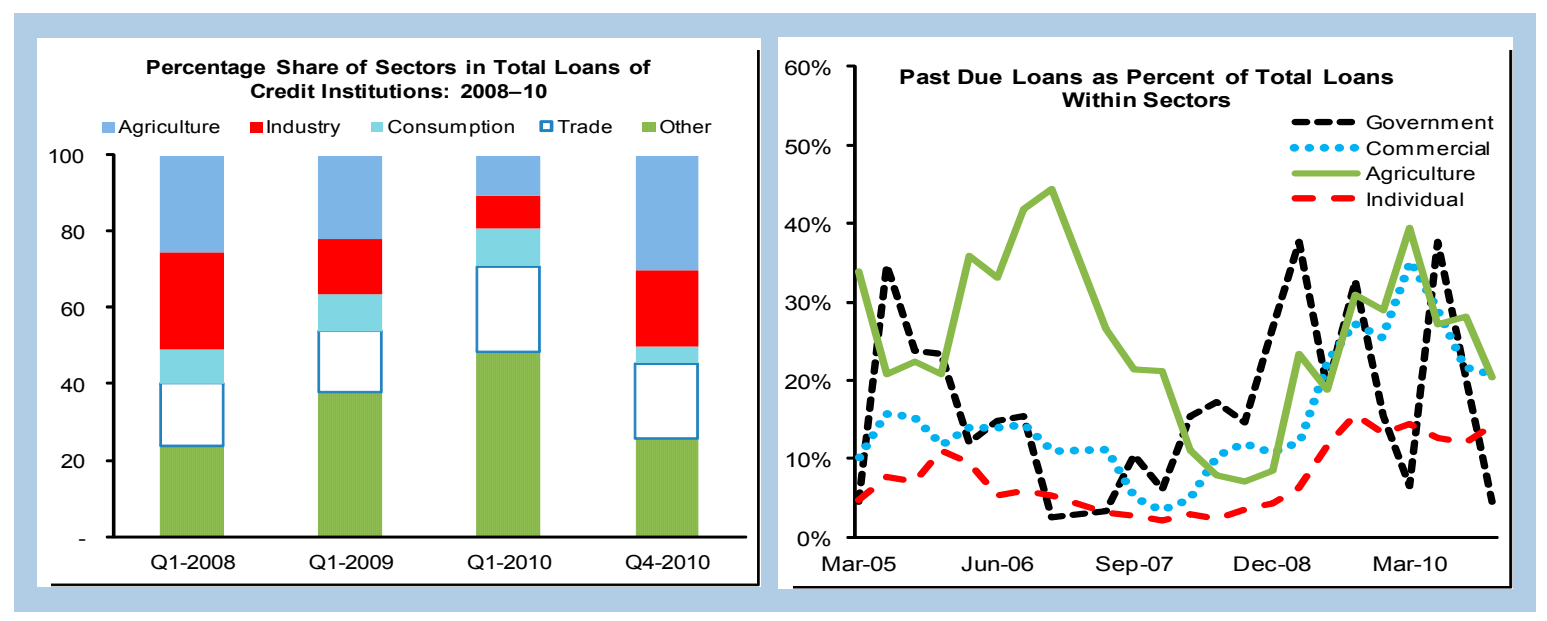

Cotton financing has been problematic. Farmers have typically borrowed from investors (rather than banks) who granted in-kind loans and were repaid in-kind. Investors enjoyed a monopoly in the provision of inputs and financing and a monopsony for the purchase of cotton output. Between 2002 and 2007 the NBT arranged credit lines from international banks for investors-backed by foreign exchange reserves. The failure of investors to repay these loans led to the loss of the foreign reserves of the NBT and its negative capital position. Since 2008, the Ministry of Finance has provided credit to banks which have been on-lent to farmers. Repayment rates were low, however, leading to NPLs. In the last three years, alternative financing has been provided by the Tajik Agricultural Financing Framework (TAFF) and the World Bank. Working with local financial intermediaries and accompanied by technical assistance to train their staff, repayment rates of these loans have been high.

The recent increase in cotton prices and resulting investor interest has precluded the need for additional public or commercial bank funds this year. In light of projected future declines in cotton prices, however, agricultural financing needs to be put on a stronger footing, which could be done in several ways: (1) ensuring an end to directed lending while simultaneously addressing the overhang of banks' nonperforming assets related to agriculture; (2) enabling banks to better assess agricultural credit risks, including through the opening of local branches and establishment of credit bureaus; (3) preventing further moral hazard by insisting that investors repay cotton loans to the NBT; and (4) increasing farmers' abilities and incentives to repay their loans - important steps include full implementation of the Freedom to Farm Act, and the freedom to independently buy inputs, gin, and sell output. Finally, if support to fill a financing gap is needed, such support should be through the budget and thereby subject to greater financial discipline and competing priorities. 
Table 1. Tajikistan: Selected Economic Indicators, 2008-16

\begin{tabular}{|c|c|c|c|c|c|c|c|c|c|}
\hline & $\begin{array}{r}2008 \\
\text { Act. }\end{array}$ & $\begin{array}{r}2009 \\
\text { Act. }\end{array}$ & $\begin{array}{r}2010 \\
\text { Act. }\end{array}$ & $\begin{array}{r}2011 \\
\text { Proj. }\end{array}$ & $\begin{array}{r}2012 \\
\text { Proj. }\end{array}$ & $\begin{array}{r}2013 \\
\text { Proj. }\end{array}$ & $\begin{array}{r}2014 \\
\text { Proj. }\end{array}$ & $\begin{array}{r}2015 \\
\text { Proj. }\end{array}$ & $\begin{array}{r}2016 \\
\text { Proj. }\end{array}$ \\
\hline & \multicolumn{9}{|c|}{ (Annual percent change; unless otherwise indicated) } \\
\hline \multicolumn{10}{|c|}{ 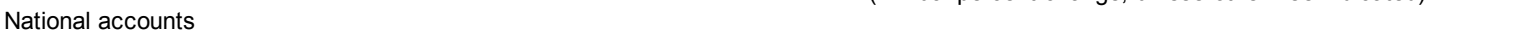 } \\
\hline Real GDP & 7.9 & 3.9 & 6.5 & 5.8 & 5.0 & 5.0 & 5.0 & 5.0 & 5.0 \\
\hline GDP deflator (cumulative) & 27.7 & 12.7 & 12.5 & 18.6 & 15.8 & 13.6 & 11.0 & 11.0 & 11.0 \\
\hline Headline CPI inflation (end-of-period) & 11.9 & 5.0 & 9.8 & 12.6 & 9.8 & 7.6 & 5.0 & 5.0 & 5.0 \\
\hline Headline CPI inflation (period average) & 20.4 & 6.5 & 6.5 & 13.9 & 9.7 & 7.6 & 5.0 & 5.0 & 5.0 \\
\hline Core CPI inflation (period average) & 2.6 & 2.0 & 2.1 & $\ldots$ & $\cdots$ & $\cdots$ & $\cdots$ & $\cdots$ & $\ldots$ \\
\hline & \multicolumn{9}{|c|}{ (In percent of GDP; unless otherwise indicated) } \\
\hline \multicolumn{10}{|l|}{ Investment and saving $1 /$} \\
\hline Investment & 20.4 & 18.8 & 17.9 & 20.2 & 19.3 & 18.9 & 18.8 & 19.0 & 19.0 \\
\hline Of which:Fixed capital investment & 19.6 & 14.3 & 12.9 & 15.2 & 14.8 & 15.9 & 15.8 & 16.0 & 17.5 \\
\hline Government & 13.6 & 13.3 & 10.9 & 12.2 & 10.8 & 9.9 & 8.8 & 8.5 & 9.0 \\
\hline Private & 6.0 & 1.0 & 2.0 & 3.0 & 4.0 & 6.0 & 7.0 & 7.5 & 8.5 \\
\hline Gross national savings & 12.8 & 12.8 & 20.1 & 16.5 & 12.3 & 12.6 & 12.9 & 13.1 & 14.7 \\
\hline Public & 8.1 & 7.8 & 7.2 & 6.8 & 6.8 & 6.6 & 6.3 & 6.2 & 6.2 \\
\hline Private & 4.7 & 5.0 & 12.9 & 9.7 & 5.6 & 6.0 & 6.6 & 6.9 & 8.6 \\
\hline \multicolumn{10}{|l|}{ General Government } \\
\hline Revenue and grants & 22.1 & 23.4 & 23.2 & 22.8 & 22.4 & 22.2 & 21.9 & 21.7 & 21.8 \\
\hline Of which: tax revenue & 18.7 & 17.6 & 18.0 & 17.7 & 17.8 & 17.9 & 18.0 & 18.1 & 18.2 \\
\hline Expenditure and net lending & 27.6 & 28.8 & 26.9 & 28.2 & 26.5 & 25.5 & 24.4 & 24.1 & 24.7 \\
\hline Of which: current & 12.6 & 14.6 & 15.0 & 16.0 & 15.6 & 15.7 & 15.6 & 15.5 & 15.6 \\
\hline capital & 13.6 & 13.3 & 10.9 & 12.2 & 10.8 & 9.9 & 8.8 & 8.5 & 9.0 \\
\hline Overall balance (excl. PIP and stat. discrepancy) 6/ & 1.4 & -0.5 & -0.4 & -1.0 & -0.5 & -0.5 & 0.0 & 0.0 & 0.0 \\
\hline Overall balance (incl. PIP and stat. discrepancy) 6/ & -5.5 & -5.4 & -3.7 & -5.4 & -4.1 & -3.3 & -2.5 & -2.3 & -2.8 \\
\hline Domestic financing & -1.0 & 1.3 & -0.4 & 1.2 & 1.3 & 1.6 & 1.0 & 0.9 & 0.9 \\
\hline External financing & 6.5 & 4.2 & 4.1 & 4.2 & 2.8 & 1.7 & 1.5 & 1.4 & 1.9 \\
\hline Overall balance (incl. PIP and stat. discrepancy) + Roghun OJSC $2 /$ & -5.5 & -5.4 & -1.1 & -6.6 & -6.6 & -5.1 & -3.7 & -3.6 & -2.8 \\
\hline Total public and publicly-guaranteed debt & 30.1 & 34.7 & 36.5 & 35.2 & 36.2 & 37.1 & 37.2 & 37.0 & 35.5 \\
\hline \multicolumn{10}{|l|}{ Monetary sector } \\
\hline Broad money (12-month percent change) & 6.3 & 39.6 & 26.2 & 22.1 & 22.8 & 21.7 & 18.9 & 18.9 & 18.3 \\
\hline Reserve money (12-month percent change) & 29.6 & 39.2 & 15.8 & 21.2 & 19.8 & 14.7 & 12.0 & 10.8 & 8.6 \\
\hline Credit to private sector (12-month percent change) $7 /$ & 19.4 & -2.2 & -15.1 & 7.0 & 11.0 & 14.0 & 25.1 & 19.3 & 27.8 \\
\hline Velocity of broad money (eop) & 5.8 & 5.1 & 4.9 & 5.0 & 4.9 & 4.8 & 4.7 & 4.6 & 4.6 \\
\hline \multirow[t]{2}{*}{ Interest rate (weighted average NBT bill rate, in percent) } & 12.3 & 6.5 & 6.5 & $\cdots$ & $\cdots$ & $\cdots$ & $\cdots$ & $\ldots$ & $\ldots$ \\
\hline & \multicolumn{9}{|c|}{ (In percent of GDP; unless otherwise indicated) } \\
\hline \multicolumn{10}{|l|}{ External sector $3 /$} \\
\hline Exports of goods and services (U.S. dollar, percent change) & 12.8 & -12.7 & 28.4 & 28.9 & -4.7 & 7.0 & 7.9 & 7.5 & 7.6 \\
\hline Imports of goods and services (U.S. dollar, percent change) & 45.0 & -26.7 & 8.3 & 31.0 & 9.7 & 7.0 & 7.9 & 8.3 & 4.9 \\
\hline Current account balance & -7.6 & -5.9 & 2.2 & -3.7 & -7.0 & -6.2 & -5.9 & -5.9 & -4.3 \\
\hline Total public and publicly guaranteed external debt & 29.2 & 34.0 & 34.4 & 33.1 & 34.1 & 33.8 & 33.2 & 32.4 & 30.5 \\
\hline Gross official reserves (in U.S. dollars) 4/ & 150 & 278 & 447 & 557 & 627 & 697 & 767 & 867 & 1,017 \\
\hline in months of next year's imports $5 /$ & 0.7 & 1.2 & 1.4 & 1.6 & 1.7 & 1.8 & 1.8 & 1.9 & 2.1 \\
\hline in percent of broad money & 15.1 & 16.7 & 20.1 & 19.8 & 16.9 & 14.7 & 13.0 & 11.9 & 11.3 \\
\hline \multicolumn{10}{|l|}{ Memorandum items: } \\
\hline Nominal GDP (in millions of somoni) & 17,609 & 20,623 & 24,705 & 30,973 & 37,665 & 44,908 & 52,336 & 60,992 & 71,093 \\
\hline Nominal GDP (in millions of U.S. dollars) & 5,135 & 4,982 & 5,642 & 6,831 & 7,762 & 8,773 & 9,785 & 10,965 & 12,289 \\
\hline Nominal effective exchange rate (Index $2000=100$ ) & 82.7 & 75.0 & 69.5 & $\ldots$ & $\ldots$ & $\ldots$ & $\ldots$ & $\ldots$ & $\ldots$ \\
\hline Real effective exchange rate (Index $2000=100$ ) & 104.1 & 97.3 & 92.4 & $\ldots$ & $\ldots$ & $\ldots$ & $\ldots$ & $\ldots$ & $\ldots$ \\
\hline Average exchange rate (somoni per U.S. dollar) & 3.43 & 4.14 & 4.38 & $\ldots$ & $\ldots$ & $\ldots$ & $\ldots$ & $\ldots$ & $\ldots$ \\
\hline
\end{tabular}

Sources: Data provided by the Tajikistan authorities, and Fund staff estimates.

1/ Private investment and savings are estimates. Investment includes changes in stocks.

2/ For consolidation, Roghun equity sales in 2010-11 are added to general government revenue. Over 2011-15, it is assumed that the

remaining financing needs of Roghun OJSC are met from external sources at consessional terms.

3/ Receipts from aluminium exports under the tolling arrangements are booked as services exports.

4/ Includes SDR 81.2 million allocation in Q3 2009.

5 / Excluding electricity, which is on barter basis, and imports related to projects financed with loans from China.

6/ For 2012-15, financing will partly come from yet to be identified fiscal measures.

7/ Decline in 2010 is due to resolution of Kredit Invest (KI) carrying large nonperfoming loans to the cotton sector. 
Table 2. Tajikistan: General Government Operations, 2008-11 (In millions of somoni; unless otherwise indicated)

\begin{tabular}{|c|c|c|c|c|c|c|}
\hline & 2008 & 2009 & & 2010 & & 2011 \\
\hline & & & $\begin{array}{r}\mathrm{H} 1 \\
\text { Act. }\end{array}$ & $\begin{array}{r}\text { Year } \\
\text { EBS/10/206 } \\
\end{array}$ & $\begin{array}{l}\text { Year } \\
\text { Act. }\end{array}$ & Proj. \\
\hline Overall revenues and grants & 3,895 & 4,828 & 2,350 & 5,570 & 5,722 & 7,070 \\
\hline Total revenues & 3,610 & 4,120 & 2,218 & 5,047 & 5,153 & 6,417 \\
\hline Tax revenues & 3,289 & 3,635 & 1,953 & 4,512 & 4,436 & 5,478 \\
\hline Income and profit tax & 453 & 609 & 362 & 784 & 780 & 904 \\
\hline Payroll taxes & 346 & 481 & 258 & 594 & 567 & 730 \\
\hline Property taxes & 121 & 143 & 67 & 158 & 152 & 197 \\
\hline Taxes on goods and services & 2,081 & 2,122 & 1,117 & 2,641 & 2,582 & 3,299 \\
\hline International trade and operations tax & 288 & 280 & 148 & 335 & 355 & 349 \\
\hline Nontax revenues & 320 & 485 & 265 & 535 & 718 & 940 \\
\hline Of which: Extra-budgetary funds & 176 & 270 & 134 & 284 & 404 & 430 \\
\hline Grants & 286 & 709 & 132 & 523 & 568 & 653 \\
\hline Of which: Public Investment Program (PIP) financing & 135 & 332 & 85 & 322 & 367 & 492 \\
\hline Total expenditures and net lending & 4,786 & 5,906 & 2,609 & 6,652 & 6,457 & 8,758 \\
\hline Current expenditures & 2,223 & 3,017 & 1,598 & 3,984 & 3,698 & 4,956 \\
\hline Expenditures on goods and services & 1,525 & 2,009 & 1,065 & 2,727 & 2,414 & 3,410 \\
\hline Wages and salaries & 726 & 971 & 525 & 1,141 & 1,141 & 1,452 \\
\hline Others & 799 & 1,038 & 540 & 1,585 & 1,274 & 1,958 \\
\hline Of which: extra-budgetary funds & 222 & 170 & 158 & 284 & 362 & 430 \\
\hline Interest payments & 54 & 104 & 50 & 127 & 121 & 190 \\
\hline $\begin{array}{l}\text { External } \\
\text { Domestic }\end{array}$ & $\begin{array}{r}53 \\
2\end{array}$ & $\begin{array}{l}88 \\
15\end{array}$ & $\begin{array}{r}50 \\
0\end{array}$ & $\begin{array}{r}105 \\
23\end{array}$ & $\begin{array}{r}100 \\
0\end{array}$ & $\begin{array}{r}159 \\
31\end{array}$ \\
\hline Transfers and subsidies & 643 & 904 & 483 & 1,130 & 1,162 & 1,356 \\
\hline Transfers to households & 593 & 837 & 450 & 981 & 1,087 & 1,221 \\
\hline Subsidies and other current transfers & 51 & 68 & 33 & 149 & 75 & 136 \\
\hline Capital expenditures & 2,401 & 2,736 & 923 & 2,522 & 2,693 & 3,796 \\
\hline Externally financed PIP & 1,344 & 1,346 & 357 & 1,157 & 1,178 & 1,884 \\
\hline Domestically financed & 1,057 & 1,390 & 566 & 1,364 & 1,515 & 1,912 \\
\hline Net lending $1 /$ & 163 & 154 & 87 & 147 & 67 & 7 \\
\hline Statistical discrepancy ("+" = additional spending) & 79 & 43 & 21 & $\ldots$ & 185 & $\ldots$ \\
\hline Overall balance (incl. PIP) & -970 & $-1,121$ & -280 & $-1,082$ & -921 & $-1,688$ \\
\hline Overall balance (excl. PIP and PIP-related grants) & 239 & -107 & -7 & -247 & -110 & -297 \\
\hline Total financing (incl. PIP) & 970 & 1,121 & 280 & 1,082 & 921 & 1,688 \\
\hline Net external & 1,149 & 858 & 224 & 1,035 & 1,020 & 1,315 \\
\hline Disbursements & 1,209 & 1,014 & 273 & 1,142 & 1,118 & 1,437 \\
\hline Program loans & 0 & 0 & 0 & 307 & 307 & 45 \\
\hline Project loans & 1,209 & 1,014 & 273 & 835 & 811 & 1,392 \\
\hline Amortization & -60 & -156 & -49 & -107 & -97 & -122 \\
\hline Net domestic & -179 & 262 & 56 & 47 & -99 & 374 \\
\hline NBT & -175 & 84 & 19 & -3 & 215 & 269 \\
\hline Commercial banks & -57 & 163 & 10 & 20 & -35 & 80 \\
\hline Operations with assets $2 /$ & 53 & 15 & 27 & 30 & -280 & 25 \\
\hline Accumulation of arrears & 0 & 0 & 0 & 0 & 0 & 0 \\
\hline Memorandum items: & & & & & & \\
\hline Recapitalization bonds-NBT 3/ & $\ldots$ & $\ldots$ & $\ldots$ & $\ldots$ & $\ldots$ & 140 \\
\hline Recapitalization bonds-commercial banks $3 /$ & $\ldots$ & $\ldots$ & 353 & $\ldots$ & 353 & $\ldots$ \\
\hline
\end{tabular}

Sources: Tajik authorities, and Fund staff estimates.

1/ Includes 140 million somoni lending to the cotton sector in 2008 and 180 million somoni in 2009.

2/ Includes transfer of MDRI deposits to the NBT in 2010 towards NBT recapitalization.

$3 /$ Issuance to compensate the NBT and banks for losses related to cotton lending as part of cotton debt resolution. 
Table 3. Tajikistan: General Government Operations, 2008-11

(In percent of GDP; unless otherwise indicated)

\begin{tabular}{|c|c|c|c|c|c|c|}
\hline & \multirow{3}{*}{$\begin{array}{l}2008 \\
\text { Act. }\end{array}$} & \multirow{3}{*}{$\begin{array}{r}2009 \\
\text { Act. }\end{array}$} & \multicolumn{3}{|c|}{2010} & \multirow{3}{*}{$\begin{array}{l}2011 \\
\text { Proj. }\end{array}$} \\
\hline & & & $\mathrm{H} 1$ & Year & Year & \\
\hline & & & Act. & EBS/10/206 & Act. & \\
\hline Overall revenues and grants & 22.1 & 23.4 & 9.5 & 22.5 & 23.2 & 22.8 \\
\hline Total revenues & 20.5 & 20.0 & 9.0 & 20.4 & 20.9 & 20.7 \\
\hline Tax revenues & 18.7 & 17.6 & 7.9 & 18.3 & 18.0 & 17.7 \\
\hline Income and profit tax & 2.6 & 3.0 & 1.5 & 3.2 & 3.2 & 2.9 \\
\hline Payroll taxes & 2.0 & 2.3 & 1.0 & 2.4 & 2.3 & 2.4 \\
\hline Property taxes & 0.7 & 0.7 & 0.3 & 0.6 & 0.6 & 0.6 \\
\hline Taxes on goods and services & 11.8 & 10.3 & 4.5 & 10.7 & 10.5 & 10.6 \\
\hline International trade and operations tax & 1.6 & 1.4 & 0.6 & 1.4 & 1.4 & 1.1 \\
\hline Nontax revenues & 1.8 & 2.3 & 1.1 & 2.2 & 2.9 & 3.0 \\
\hline Of which: Extra-budgetary funds & 1.0 & 1.3 & 0.5 & 1.1 & 1.6 & 1.4 \\
\hline Grants & 1.6 & 3.4 & 0.5 & 2.1 & 2.3 & 2.1 \\
\hline Of which: Public Investment Program (PIP) financing & 0.8 & 1.6 & 0.3 & 1.3 & 1.5 & 1.6 \\
\hline Total expenditure and net lending & 27.2 & 28.6 & 10.6 & 26.9 & 26.1 & 28.3 \\
\hline Current expenditures & 12.6 & 14.6 & 6.5 & 16.1 & 15.0 & 16.0 \\
\hline Expenditures on goods and services & 8.7 & 9.7 & 4.3 & 11.0 & 9.8 & 11.0 \\
\hline Wages and salaries & 4.1 & 4.7 & 2.1 & 4.6 & 4.6 & 4.7 \\
\hline Others & 4.5 & 5.0 & 2.2 & 6.4 & 5.2 & 6.3 \\
\hline Of which: extra-budgetary funds & 1.3 & 0.8 & 0.6 & 1.1 & 1.5 & 1.4 \\
\hline Interest payments & 0.3 & 0.5 & 0.2 & 0.5 & 0.5 & 0.6 \\
\hline External & 0.3 & 0.4 & 0.2 & 0.4 & 0.4 & 0.5 \\
\hline Domestic & 0.0 & 0.1 & 0.0 & 0.1 & 0.0 & 0.1 \\
\hline Transfers and subsidies & 3.7 & 4.4 & 2.0 & 4.6 & 4.7 & 4.4 \\
\hline Transfers to households & 3.4 & 4.1 & 1.8 & 4.0 & 4.4 & 3.9 \\
\hline Subsidies and other current transfers & 0.3 & 0.3 & 0.1 & 0.6 & 0.3 & 0.4 \\
\hline Capital expenditures & 13.6 & 13.3 & 3.7 & 10.2 & 10.9 & 12.3 \\
\hline Externally financed PIP & 7.6 & 6.5 & 1.4 & 4.7 & 4.8 & 6.1 \\
\hline Domestically financed & 6.0 & 6.7 & 2.3 & 5.5 & 6.1 & 6.2 \\
\hline Net lending $1 /$ & 0.9 & 0.7 & 0.4 & 0.6 & 0.3 & 0.0 \\
\hline Statistical discrepancy ("+" = additional spending) & 0.4 & 0.2 & 0.1 & $\ldots$ & 0.7 & $\ldots$ \\
\hline Overall balance (incl. PIP) & -5.5 & -5.4 & -1.1 & -4.4 & -3.7 & -5.5 \\
\hline Overall balance (excl. PIP and PIP-related grants) & 1.4 & -0.5 & 0.0 & -1.0 & -0.4 & -1.0 \\
\hline Total financing (incl. PIP) & 5.5 & 5.4 & 1.1 & 4.4 & 3.7 & 5.5 \\
\hline Net external & 6.5 & 4.2 & 0.9 & 4.2 & 4.1 & 4.2 \\
\hline Disbursements & 6.9 & 4.9 & 1.1 & 4.6 & 4.5 & 4.6 \\
\hline Program loans & 0.0 & 0.0 & 0.0 & 1.2 & 1.2 & 0.1 \\
\hline Project loans & 6.9 & 4.9 & 1.1 & 3.4 & 3.3 & 4.5 \\
\hline Amortization & -0.3 & -0.8 & -0.2 & -0.4 & -0.4 & -0.4 \\
\hline Net domestic & -1.0 & 1.3 & 0.2 & 0.2 & -0.4 & 1.2 \\
\hline NBT & -1.0 & 0.4 & 0.1 & 0.0 & 0.9 & 0.9 \\
\hline Commercial banks & -0.3 & 0.8 & 0.0 & 0.1 & -0.1 & 0.3 \\
\hline Operations with assets $2 /$ & 0.3 & 0.1 & 0.1 & 0.1 & -1.1 & 0.1 \\
\hline Accumulation of arrears & 0.0 & 0.0 & 0.0 & 0.0 & 0.0 & 0.0 \\
\hline \multicolumn{7}{|l|}{ Memorandum items: } \\
\hline Public debt (in percent of GDP) & 30.1 & 34.7 & $\ldots$ & 34.7 & 36.5 & 35.2 \\
\hline Nominal GDP (In millions of somoni) & 17,609 & 20,623 & $\ldots$ & 24,705 & 24,705 & 30,973 \\
\hline
\end{tabular}

Sources: Tajik authorities, and Fund staff estimates.

1/ Includes 140 million somoni lending to the cotton sector in 2008 and 180 million somoni in 2009.

2/ Includes transfer of MDRI deposits to the NBT in 2010 towards NBT recapitalization. 
Table 4. Tajikistan: Accounts of the National Bank of Tajikistan, 2008-11

(End-of-period stock; unless otherwise specified)

\begin{tabular}{|c|c|c|c|c|c|c|c|c|c|c|c|}
\hline & \multirow{2}{*}{$\begin{array}{l}2008 \\
\text { Dec. } \\
\text { Act. }\end{array}$} & \multirow{2}{*}{$\begin{array}{c}2009 \\
\text { Dec. } \\
\text { Act. }\end{array}$} & \multicolumn{5}{|c|}{2010} & \multicolumn{4}{|c|}{2011} \\
\hline & & & $\begin{array}{l}\text { March } \\
\text { Act. }\end{array}$ & $\begin{array}{l}\text { June } \\
\text { Act. }\end{array}$ & $\begin{array}{l}\text { Sept. } \\
\text { Act. }\end{array}$ & $\begin{array}{c}\text { Dec. } \\
\text { EBS/10/206 }\end{array}$ & $\begin{array}{l}\text { Dec. } \\
\text { Act. }\end{array}$ & $\begin{array}{l}\text { March } \\
\text { Proj. }\end{array}$ & $\begin{array}{l}\text { June } \\
\text { Proj. }\end{array}$ & $\begin{array}{l}\text { Sept. } \\
\text { Proj. }\end{array}$ & $\begin{array}{l}\text { Dec. } \\
\text { Proj. }\end{array}$ \\
\hline & \multicolumn{11}{|c|}{ (In millions of somoni) } \\
\hline Net foreign assets & 264 & 661 & 779 & 940 & 1,382 & 1,274 & 1,825 & 1,907 & 1,988 & 2,114 & 2,279 \\
\hline Of which: Net international reserves $1 / 2 /$ & 369 & 1,034 & 1,120 & 1,208 & 1,631 & 1,544 & 1,650 & 1,731 & 1,809 & 1,932 & 2,092 \\
\hline Gross reserves 2/ & 519 & 1,217 & 1,353 & 1,549 & 1,996 & 1,975 & 2,096 & 2,181 & 2,359 & 2,491 & 2,761 \\
\hline Net domestic assets & 1,592 & 1,922 & 1,447 & 1,333 & 1,324 & 1,753 & 1,164 & 1,140 & 1,234 & 1,287 & 1,343 \\
\hline Net credit to general government & -949 & -865 & $-1,350$ & $-1,276$ & $-1,244$ & -735 & -994 & -900 & -787 & -714 & -654 \\
\hline General government & -949 & -860 & -896 & -841 & -737 & -506 & -645 & -551 & -439 & -366 & -373 \\
\hline Roghun JSC & $\ldots$ & -5 & -455 & -435 & -507 & -228 & -349 & -349 & -349 & -349 & -281 \\
\hline Credit to the private sector $3 /$ & 2,359 & 1,687 & 2,542 & 2,684 & 2,939 & 2,842 & 945 & 841 & 854 & 865 & 912 \\
\hline Claims on banks & 2,241 & 1,577 & 2,444 & 2,522 & 2,392 & 2,295 & 334 & 230 & 243 & 253 & 300 \\
\hline \multicolumn{12}{|l|}{ Of which: } \\
\hline Cotton sector & 2,019 & 1,247 & 2,133 & 2,361 & 1,977 & 1,977 & 0 & 0 & 0 & 0 & 0 \\
\hline NBT bills & 0 & 0 & 0 & -63 & -8 & 0 & -3 & -209 & -105 & -70 & -1 \\
\hline Liquidity loans & 40 & 164 & 154 & 78 & 265 & 147 & 186 & 287 & 197 & 172 & 150 \\
\hline Credit to non bank institutions & 118 & 110 & 98 & 162 & 547 & 547 & 611 & 611 & 611 & 611 & 611 \\
\hline Other items, net & 182 & 1,100 & 255 & -76 & -372 & -355 & 1,213 & 1,198 & 1,167 & 1,136 & 1,086 \\
\hline Of which: Retained profits and provisions (+ losses) & 2,143 & 2,271 & $\ldots$ & $\ldots$ & $\ldots$ & $\ldots$ & $\ldots$ & $\ldots$ & $\ldots$ & $\ldots$ & $\ldots$ \\
\hline Reserve money & 1,856 & 2,583 & 2,225 & 2,273 & 2,706 & 3,027 & 2,990 & 3,047 & 3,222 & 3,401 & 3,622 \\
\hline Currency in circulation & 1,566 & 2,041 & 1,842 & 1,961 & 2,195 & 2,543 & 2,421 & 2,407 & 2,545 & 2,686 & 2,861 \\
\hline Bank reserves & 278 & 533 & 380 & 311 & 509 & 483 & 565 & 637 & 673 & 711 & 759 \\
\hline Required reserves & 157 & 181 & 193 & 192 & 221 & 329 & 234 & 335 & 373 & 414 & 379 \\
\hline \multirow[t]{2}{*}{ Other bank deposits } & 121 & 353 & 187 & 119 & 288 & 154 & 331 & 302 & 301 & 297 & 380 \\
\hline & \multicolumn{11}{|c|}{ (12-month growth in percent of reserve money) } \\
\hline Reserve money & 29.6 & 39.2 & 33.2 & 23.5 & 24.7 & 17.2 & 15.8 & 36.9 & 41.8 & 25.7 & 21.2 \\
\hline Net foreign assets & -44.9 & 21.4 & 32.6 & 35.1 & 46.3 & 23.8 & 45.1 & 50.7 & 46.1 & 27.0 & 15.2 \\
\hline Of which: gross international reserves & 15.6 & 37.6 & 57.5 & 53.3 & 37.5 & 29.4 & 34.0 & 37.2 & 35.6 & 18.3 & 22.2 \\
\hline Of which: net international reserves & 17.3 & 35.8 & 53.0 & 49.5 & 33.2 & 19.8 & 23.9 & 27.5 & 26.5 & 11.1 & 14.8 \\
\hline Net domestic assets & 74.5 & 17.8 & 0.6 & -11.6 & -21.6 & -6.6 & -29.3 & -13.8 & -4.3 & -1.4 & 6.0 \\
\hline Net credit to general government & -12.2 & 4.5 & -14.4 & -15.1 & -12.0 & 5.0 & -5.0 & 20.2 & 21.5 & 19.6 & 11.4 \\
\hline Credit to the private sector & 83.6 & -36.2 & 2.7 & -0.1 & 3.2 & 44.7 & -28.7 & -76.4 & -80.5 & -76.7 & -1.1 \\
\hline Of which: NBT bills & 0.7 & 0.0 & 0.0 & -3.0 & -0.1 & 0.0 & -0.1 & -9.4 & -1.8 & -2.3 & 0.1 \\
\hline Other items net & 3.1 & 49.4 & 12.3 & 3.6 & -12.8 & -56.3 & 4.4 & 42.4 & 54.7 & 55.7 & -4.2 \\
\hline \multicolumn{12}{|l|}{ Memorandum items: } \\
\hline Net international reserves (in millions of U.S.dollars) & 107 & 236 & 256 & 276 & 372 & 350 & 375 & 390 & 400 & 420 & 444 \\
\hline Net international reserves (percent of broad money) & 12.7 & 25.6 & 30.2 & 30.1 & 36.0 & 31.8 & 32.5 & 32.3 & 32.1 & 32.6 & 33.6 \\
\hline Official exchange rate (somoni/U.S. dollars) & 3.45 & 4.37 & 4.37 & 4.38 & 4.38 & $\ldots$ & 4.40 & $\ldots$ & $\ldots$ & $\ldots$ & $\ldots$ \\
\hline Guarantee settlement (in millions of U.S. dollars) & $\ldots$ & 38 & $\ldots$ & $\ldots$ & $\ldots$ & $\ldots$ & $\ldots$ & $\ldots$ & $\ldots$ & $\ldots$ & $\ldots$ \\
\hline
\end{tabular}

Sources: National Bank of Tajikistan, and Fund staff estimates.

1/ Includes SDR 81.2 million allocation in Q3 2009.

2/ Excludes nonmonetary gold.

$3 /$ Increase in the beginning of 2010 reflects reclassification of credits to $\mathrm{KI}$ according to debt resolution strategy. 
Table 5. Tajikistan: Monetary Survey, 2008-11

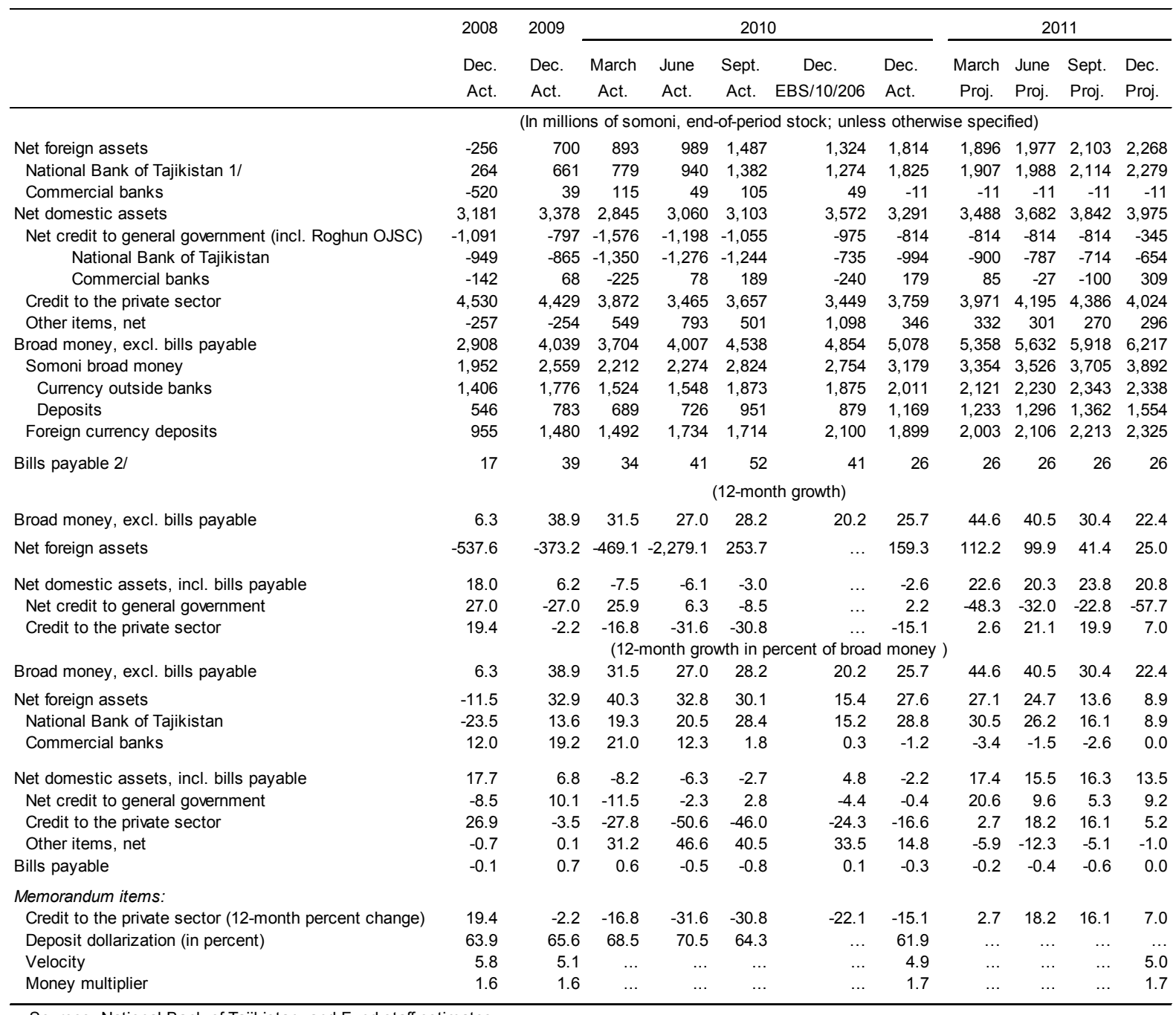

Sources: National Bank of Tajikistan, and Fund staff estimates.

1/ Revised from EBS/09/43 to exclude nonmonetary gold.

2/ Liabilities to cotton financiers related to domestic cotton financing. 
Table 6. Tajikistan: Balance of Payments, 2008-16

(In millions of U.S. dollars, unless otherwise indicated)

\begin{tabular}{|c|c|c|c|c|c|c|c|c|c|}
\hline & 2008 & 2009 & 2010 & 2011 & 2012 & 2013 & 2014 & 2015 & 2016 \\
\hline & Act. & Act. & Proj. & Proj. & Proj. & Proj. & Proj. & Proj. & Proj. \\
\hline Current account & -392 & -295 & 123 & -253 & -543 & -548 & -577 & -648 & -527 \\
\hline Balance on goods and services $1 /$ & $-2,838$ & $-1,958$ & $-1,970$ & $-2,600$ & $-3,034$ & $-3,246$ & $-3,501$ & $-3,804$ & $-3,948$ \\
\hline Balance on goods & $-2,721$ & $-1,980$ & $-2,007$ & $-2,601$ & $-3,027$ & $-3,219$ & $-3,490$ & $-3,824$ & $-3,974$ \\
\hline Exports & 457 & 408 & 575 & 827 & 744 & 801 & 852 & 921 & 997 \\
\hline Imports & $-3,178$ & $-2,388$ & $-2,582$ & $-3,428$ & $-3,772$ & $-4,020$ & $-4,342$ & $-4,745$ & $-4,971$ \\
\hline Balance on services & -117 & 22 & 37 & 0 & -7 & -27 & -12 & 19 & 26 \\
\hline Balance on income & -53 & -71 & -70 & -63 & -66 & -72 & -80 & -87 & -90 \\
\hline Balance on transfers & 2,499 & 1,735 & 2,162 & 2,410 & 2,557 & 2,769 & 3,004 & 3,243 & 3,511 \\
\hline Of which: migrants' remittances, net & 2,343 & 1,622 & 2,040 & 2,293 & 2,476 & 2,699 & 2,942 & 3,207 & 3,479 \\
\hline Capital and financial account & 488 & 382 & -83 & 272 & 382 & 438 & 501 & 587 & 670 \\
\hline Capital transfers & 39 & 120 & 84 & 108 & 86 & 79 & 49 & 51 & 70 \\
\hline Public sector (net) & 313 & 209 & 140 & 272 & 201 & 145 & 142 & 155 & 236 \\
\hline Disbursements & 352 & 241 & 185 & 265 & 237 & 245 & 245 & 256 & 350 \\
\hline Of which: projects financed by China & 277 & 137 & 108 & 119 & 105 & 150 & 150 & 150 & 150 \\
\hline Amortization & -39 & -32 & -45 & -32 & -76 & -101 & -104 & -101 & -115 \\
\hline FDI & 300 & 16 & 49 & 110 & 190 & 263 & 294 & 329 & 430 \\
\hline Commercial bank NFA (- increase) & -94 & -161 & 11 & 0 & 0 & 0 & 0 & 0 & 0 \\
\hline NBT $2 /$ & 241 & 28 & 0 & 0 & 0 & 0 & 0 & 0 & 0 \\
\hline Other capital flows and errors and omissions $3 / 4 /$ & -311 & 171 & -367 & -218 & -95 & -49 & 17 & 52 & -66 \\
\hline Overall balance & 96 & 88 & 39 & 19 & -160 & -110 & -76 & -62 & 0 \\
\hline Overall balance (excluding budget support grants) & 96 & 11 & -7 & -37 & -193 & -142 & -108 & -94 & 142 \\
\hline Financing items & -96 & -128 & -169 & -110 & -70 & -70 & -74 & -112 & -172 \\
\hline Use of international reserves (- increase) & -65 & -128 & -169 & -110 & -70 & -70 & -70 & -100 & -150 \\
\hline IMF disbursements & -31 & -15 & 0 & 0 & 0 & 0 & -4 & -12 & -22 \\
\hline Exceptional financing 5/ & $\ldots$ & 15 & 0 & 0 & 0 & 0 & 0 & 0 & 0 \\
\hline Financing gap & 0 & 117 & 176 & 147 & 263 & 212 & 182 & 206 & 30 \\
\hline IMF & $\ldots$ & 40 & 60 & 41 & 20 & 0 & 0 & 0 & 0 \\
\hline Other identified and potential financing & $\ldots$ & 76 & 116 & 107 & 83 & 32 & 32 & 32 & 30 \\
\hline World Bank 6/ & $\ldots$ & 21 & 25 & 10 & 10 & $\ldots$ & $\ldots$ & $\ldots$ & $\ldots$ \\
\hline AsDB 6/ & $\ldots$ & 40 & 10 & 35 & 10 & $\ldots$ & $\ldots$ & $\ldots$ & $\ldots$ \\
\hline EC 6/ & $\ldots$ & 16 & 11 & 12 & 13 & $\ldots$ & $\ldots$ & $\ldots$ & $\ldots$ \\
\hline Anti-crisis Fund & $\ldots$ & $\ldots$ & 70 & 50 & 50 & $\ldots$ & $\ldots$ & $\ldots$ & $\ldots$ \\
\hline Residual financing gap $7 /$ & $\ldots$ & $\ldots$ & $\ldots$ & $\ldots$ & 160 & 180 & 150 & 174 & $\ldots$ \\
\hline \multicolumn{10}{|l|}{ Memorandum items: } \\
\hline Nominal GDP & 5,135 & 4,982 & 5,642 & 6,830 & 7,762 & 8,773 & 9,785 & 10,965 & 12,289 \\
\hline Current account balance (in percent of GDP) & -7.6 & -5.9 & 2.2 & -3.7 & -7.0 & -6.2 & -5.9 & -5.9 & -4.3 \\
\hline Gross reserves & 150 & 278 & 447 & 557 & 627 & 697 & 767 & 867 & 1017 \\
\hline (in months of next year's imports of goods and services) $8 /$ & 0.7 & 1.2 & 1.4 & 1.6 & 1.7 & 1.8 & 1.8 & 1.9 & 2.1 \\
\hline Total Public and Publicly Guaranteed (PPG) external sector debt 9/ & 1,498 & 1,692 & 1,942 & 2,260 & 2,646 & 2,969 & 3,245 & 3,548 & 3,751 \\
\hline (in percent of GDP) & 29.2 & 34.0 & 34.4 & 33.1 & 34.1 & 33.8 & 33.2 & 32.4 & 30.5 \\
\hline Debt service on PPG external debt & 91 & 153 & 71 & 64 & 112 & 140 & 150 & 159 & 188 \\
\hline (in percent of exports of goods and services) & 10.5 & 20.3 & 7.3 & 5.2 & 9.4 & 11.0 & 10.9 & 10.8 & 11.8 \\
\hline
\end{tabular}

Sources: Tajik authorities, and Fund staff estimates.

1/ Starting from 2005, the export and import figures reflect the transition to the tolling arrangement for aluminium exports.

2/ Includes SDR 82.1 million allocation to Tajikistan in Q3 2009.

$3 /$ Includes change in foreign currency balances held by residents of Tajikistan.

4/ For 2008, includes the decline in other foreign liabilities which resulted from pledged deposits settlement.

5/ Pakistan's government converted Tajikistan's debt into a grant.

6/ Budget support grants.

7/ The financing gap in 2012-15 includes financing for the Roghun HPP. The World Bank feasibility study,instrumental in identifying the financing is ongoing.

8/ Excluding electricity, which is on barter basis, and imports related to projects financed with loans from China.

9/ External debt is defined as debt to nonresidents. 
Table 7. Tajikistan: External Financing Requirements and Sources, 2008-15 (In millions of U.S. dollars)

\begin{tabular}{|c|c|c|c|c|c|c|c|c|}
\hline & & & \multicolumn{6}{|c|}{ IMF Staff Projections } \\
\hline & 2008 & 2009 & 2010 & 2011 & 2012 & 2013 & 2014 & 2015 \\
\hline Total requirements & 431 & 327 & -78 & 286 & 618 & 649 & 680 & 730 \\
\hline Current account deficit & 392 & 295 & -123 & 253 & 543 & 548 & 577 & 628 \\
\hline Debt amortization & 39 & 32 & 45 & 32 & 76 & 101 & 104 & 101 \\
\hline Multilateral 1/ & 8 & 12 & 13 & 19 & 38 & 44 & 49 & 44 \\
\hline Bilateral & 31 & 20 & 32 & 14 & 38 & 56 & 55 & 57 \\
\hline Total sources & 527 & 415 & -38 & 305 & 458 & 539 & 605 & 668 \\
\hline Capital inflows & 527 & 415 & -38 & 305 & 458 & 539 & 605 & 668 \\
\hline Foreign direct investment & 300 & 16 & 49 & 110 & 190 & 263 & 294 & 329 \\
\hline Disbursement from official creditors $2 /$ & 391 & 362 & 269 & 413 & 363 & 324 & 294 & 307 \\
\hline Other flows $3 /$ & -164 & 37 & -356 & -218 & -95 & -49 & 16 & 31 \\
\hline Change in reserves (- increase) & -65 & -128 & -169 & -110 & -70 & -70 & -70 & -100 \\
\hline Financing gap & -31 & 40 & 130 & 91 & 230 & 180 & 146 & 162 \\
\hline Financing gap (excluding budget support grants) & -31 & 117 & 176 & 147 & 263 & 212 & 178 & 194 \\
\hline Financing items $4 /$ & -31 & 117 & 176 & 147 & 263 & 212 & 178 & 194 \\
\hline IMF 5/ & -31 & 25 & 60 & 41 & 20 & 0 & -4 & -12 \\
\hline Other financing & 0 & 92 & 116 & 107 & 243 & 212 & 182 & 206 \\
\hline AsDB & $\ldots$ & 40 & 10 & 35 & 10 & 10 & 10 & 10 \\
\hline EC & $\ldots$ & 16 & 11 & 12 & 13 & 12 & 12 & 12 \\
\hline World Bank & 0 & 21 & 25 & 10 & 10 & 10 & 10 & 10 \\
\hline Anti-Crisis Fund & $\cdots$ & $\cdots$ & 70 & 50 & 50 & 0 & 0 & 0 \\
\hline Exceptional financing & 0 & 15 & 0 & 0 & 0 & 0 & 0 & 0 \\
\hline Unidentified financing & 0 & 0 & 0 & 0 & 160 & 180 & 150 & 174 \\
\hline
\end{tabular}

Sources: Tajik authorities, and Fund staff calculations.

1/ Excluding the IMF.

2/ Includes project loans and grants.

3/ Includes all other net financial flows, and errors and omissions.

$4 /$ Includes estimates for potential financing.

$5 /$ Net of repurchases. 
Table 8. Tajikistan: Capacity to Repay the Fund, 2010-20

\begin{tabular}{|c|c|c|c|c|c|c|c|c|c|c|c|}
\hline & 2010 & 2011 & 2012 & 2013 & 2014 & 2015 & 2016 & 2017 & 2018 & 2019 & 2020 \\
\hline \multicolumn{12}{|l|}{ Existing and prospective Fund credit 1/ } \\
\hline In millions of SDRs & 65.3 & 91.4 & 104.4 & 104.4 & 101.8 & 94.0 & 79.6 & 60.0 & 39.2 & 20.9 & 7.8 \\
\hline In millions of U.S. dollars & 99.6 & 143.0 & 163.4 & 163.4 & 159.4 & 147.1 & 124.6 & 94.0 & 61.3 & 32.7 & 12.3 \\
\hline In percent of exports & 10.3 & 11.4 & 13.7 & 12.8 & 11.6 & 10.0 & 7.8 & 5.4 & 3.2 & 1.5 & 0.5 \\
\hline In percent of external debt & 3.3 & 4.2 & 4.2 & 3.7 & 3.2 & 2.7 & 2.1 & 1.5 & 1.0 & 0.5 & 0.2 \\
\hline In percent of gross reserves & 22.3 & 25.7 & 26.0 & 23.4 & 20.8 & 17.0 & 12.2 & 8.0 & 4.7 & 2.2 & 0.8 \\
\hline In percent of quota & 75.0 & 105.0 & 120.0 & 120.0 & 117.0 & 108.0 & 91.5 & 69.0 & 45.0 & 24.0 & 9.0 \\
\hline \multicolumn{12}{|l|}{ Fund obligation based on existing credit } \\
\hline In millions of SDRs & 0.0 & 0.0 & 0.2 & 0.2 & 2.8 & 8.0 & 13.2 & 13.1 & 13.1 & 10.5 & 5.2 \\
\hline In millions of U.S. dollars & 0.0 & 0.1 & 0.3 & 0.3 & 4.3 & 12.5 & 20.6 & 20.6 & 20.5 & 16.4 & 8.2 \\
\hline In percent of exports & 0.0 & 0.0 & 0.0 & 0.0 & 0.3 & 0.8 & 1.3 & 1.2 & 1.1 & 0.8 & 0.4 \\
\hline In percent of external debt & 0.0 & 0.0 & 0.0 & 0.0 & 0.1 & 0.2 & 0.4 & 0.3 & 0.3 & 0.2 & 0.1 \\
\hline In percent of gross reserves & 0.0 & 0.0 & 0.1 & 0.0 & 0.8 & 2.0 & 3.1 & 2.9 & 2.8 & 2.2 & 1.0 \\
\hline In percent of quota & 0.0 & 0.0 & 0.2 & 0.2 & 3.2 & 9.2 & 15.1 & 15.1 & 15.1 & 12.0 & 6.0 \\
\hline \multicolumn{12}{|l|}{$\begin{array}{l}\text { Fund obligation based on existing and } \\
\text { prospective credit }\end{array}$} \\
\hline In millions of SDRs & 0.0 & 0.0 & 0.3 & 0.3 & 2.9 & 8.1 & 14.6 & 19.8 & 21.0 & 18.4 & 13.1 \\
\hline In millions of U.S. dollars & 0.0 & 0.0 & 0.4 & 0.4 & 4.5 & 12.6 & 22.8 & 30.9 & 32.9 & 28.7 & 20.5 \\
\hline In percent of exports & 0.0 & 0.0 & 0.0 & 0.0 & 0.3 & 0.9 & 1.4 & 1.8 & 1.7 & 1.4 & 0.9 \\
\hline In percent of external debt & 0.0 & 0.0 & 0.0 & 0.0 & 0.1 & 0.2 & 0.4 & 0.5 & 0.5 & 0.4 & 0.3 \\
\hline In percent of gross reserves & 0.0 & 0.0 & 0.1 & 0.1 & 0.8 & 2.0 & 3.4 & 4.4 & 4.5 & 3.8 & 2.6 \\
\hline In percent of quota & 0.0 & 0.0 & 0.3 & 0.3 & 3.3 & 9.3 & 16.8 & 22.7 & 24.1 & 21.1 & 15.0 \\
\hline \multicolumn{12}{|l|}{ Memorandum items: } \\
\hline Gross reserves (in millions of U.S. dollars) & 447 & 557 & 627 & 697 & 767 & 867 & 1,017 & 1,167 & 1,317 & 1,467 & 1,617 \\
\hline Quota (in millions of SDRs) & 87 & 87 & 87 & 87 & 87 & 87 & 87 & 87 & 87 & 87 & 87 \\
\hline
\end{tabular}

Sources: Tajik authorities, and Fund staff estimates.

$1 /$ End of period. 
Table 9. Tajikistan: Reviews and Disbursements under the Three-Year ECF Arrangement, 2009-12 1/

\begin{tabular}{|c|c|c|c|c|}
\hline Date & Action & $\begin{array}{c}\text { Original } \\
\text { Disbursements } \\
\text { (in million SDRs) } \\
\end{array}$ & $\begin{array}{l}\text { Augmentation } \\
\text { (in million SDRs) } \\
\end{array}$ & $\begin{array}{c}\text { Disbursements After } \\
\text { Augmentation } \\
\text { (in million SDRs) }\end{array}$ \\
\hline On May 7, 2009 & Approval of the ECF arrangement & 26.100 & $\ldots$ & 26.100 \\
\hline On or after April 15, 2010 & Completion of the first and second reviews & 26.120 & $\ldots$ & 26.120 \\
\hline On or after September 15, 2010 & Completion of the third review & 6.523 & 6.523 & 13.045 \\
\hline On or after March 15, 2011 & Completion of the fourth review & 6.523 & 6.523 & 13.045 \\
\hline On or after September 15, 2011 & Completion of the fifth review & 6.523 & 6.523 & 13.045 \\
\hline On or after March 15, 2012 & Completion of the sixth review & 6.523 & 6.523 & 13.045 \\
\hline
\end{tabular}

Source: Fund staff estimates.

1/ This table assumes SDR 26.1 million augmentation of the existing ECF in 2009-12. 
Table 10. Tajikistan: Financial Soundness Indicators, 2004-10

(In percent; unless otherwise indicated)

\begin{tabular}{|c|c|c|c|c|c|c|c|c|c|}
\hline & 2004 & 2005 & 2006 & 2007 & 2008 & 2009 & Jun-10 & Sep-10 & Dec-10 \\
\hline \multicolumn{10}{|l|}{ Capital adequacy } \\
\hline Tier I capital as percent of risk-weighted assets & 38.7 & 34.2 & 27.8 & 19.4 & 24.2 & 25.4 & 23.8 & 22.9 & 24.5 \\
\hline Reported total capital to risk -weighted assets (K1-1) & 44.7 & 37.9 & 30.4 & 21.3 & 29.2 & 30.0 & 26.3 & 24.6 & 26.3 \\
\hline \multicolumn{10}{|l|}{ Asset quality $1 /$} \\
\hline Nonperforming loans to gross loans & 20.6 & 14.3 & 11.3 & 4.8 & 9.5 & 21.6 & 24.1 & 19.7 & 17.2 \\
\hline excluding Agroinvestbank & n.a. & n.a & n.a. & n.a. & n.a. & n.a. & n.a. & n.a. & \\
\hline Nonperforming loans to gross loans $2 /$ & n.a. & n.a & 4.1 & 2.8 & 5.4 & 10.4 & 13.5 & 11.9 & 7.5 \\
\hline Nonperforming loans net of provisions to reg. capital & 19.3 & 16.1 & 18.2 & 8.2 & 16.8 & 38.5 & 44.8 & 35.2 & 31.2 \\
\hline Provisions to nonperforming loans & 47.2 & 36.8 & 27.8 & 40.5 & 32.5 & 29.4 & 30.5 & 37.9 & 35.9 \\
\hline Banks exceeding maximum single borrower limit $3 /$ & $30 f 12$ & 2 of12 & 1 of9 & 1 of 10 & 1 of12 & 1 of13 & 2 of 14 & 4 of 14 & 0 of 14 \\
\hline \multicolumn{10}{|l|}{ Earnings and profitability } \\
\hline Reported return on assets (ROA) & 2.9 & 4.7 & 3.8 & 2.7 & 2.0 & 0.8 & -1.7 & -0.6 & 0.8 \\
\hline Reported return on equity (ROE) & 10.2 & 17.2 & 16.1 & 16.8 & 11.0 & 3.4 & -7.9 & -3.0 & 3.8 \\
\hline Interest income to gross income & 42.7 & 48.2 & 47.9 & 57.5 & 59.6 & 53.0 & 49.6 & 48.6 & 51.4 \\
\hline Non-interest expenditures to gross income & 61.0 & 55.2 & 63.2 & 59.7 & 55.3 & 67.1 & 60.7 & 70.1 & 63.9 \\
\hline Salary expenditures to non-interest expenditures & 25.8 & 27.1 & 21.6 & 26.5 & 32.1 & 21.1 & 26.8 & 22.9 & 23.2 \\
\hline \multicolumn{10}{|l|}{ Liquidity } \\
\hline Liquid assets to total assets & 36.9 & 30.0 & 39.9 & 39.9 & 27.2 & 28.2 & 23.4 & 24.6 & 24.2 \\
\hline Liquid assets to demand and savings deposits & 113.5 & 80.2 & 84.0 & 112.6 & 104.1 & 112.2 & 109.7 & 125.3 & 133.5 \\
\hline Liquid assets to total deposits & 71.2 & 54.9 & 57.9 & 61.3 & 60.0 & 56.6 & 50.9 & 53.5 & 49.8 \\
\hline \multicolumn{10}{|l|}{ Sensitivity to market risk } \\
\hline Net open position in foreign exchange to capital & 36.3 long & 8.8 long & 5.9 long & 13.4 long & 6.3 long & 6.7 long & 6.1 long & 8.5 long & 0.33 short \\
\hline
\end{tabular}

Sources: National Bank of Tajikistan.

1/ Nonperforming loans includes loans more than 1 day overdue.

2/ Nonperforming loans includes loans more than 30 day overdue.

3/ Maximum single borrower limit is defined as 25 percent of capital (K3-1). 


\section{ATTACHMENT I. TAJIKISTAN: LETTER OF INTENT}

April 19, 2011

His Excellency

Mr. Dominique Strauss-Kahn

Managing Director

International Monetary Fund

70019 th Street, N.W.

Washington, DC 20431

Dear Mr. Strauss-Kahn:

I would like to express my gratitude to the International Monetary Fund (IMF) for its continued support of our economic reforms. Tajikistan is emerging from the worst of the global economic crisis. However, we are of the view that economic and financial risks remain, and that work must continue to address the damage caused during the crisis. Continued support from the international financial institutions (IFIs) and donors will be critical.

Economic performance in 2010 was strong. Real GDP growth registered some 6.5 percent, fueled by power production, construction, beneficial increases in cotton and aluminum prices, and higher remittances. This was a welcome recovery from low growth in 2009, and we will seek to foster this nascent recovery in 2011. We were not without challenges, however. Reflecting trends in international markets, food prices rose in the second half of the year, contributing to higher-than-expected inflation. Financial sector indicators also remain a concern, and we intend to devote more attention to finding a solution for this problem.

I am pleased to report that, with three exceptions (the continuous performance criterion on the non-accumulation of external payments arrears, and the indicative targets on government social spending and on liquidity loans from the NBT), we met all the quantitative targets for end-December 2010. Despite considerable external shocks, we managed to continue building international reserves through the course of the year, maintain a prudent fiscal stance, and meet our budgetary objectives for health and education spending as well as for critical infrastructure. Out of concern for meeting the overall fiscal target, however, we restricted the increase in public wages and salaries for 2010, and did not fill a number of vacancies, which contributed to lower social sector spending than expected.

Liquidity lending from the National Bank of Tajikistan (NBT) to commercial banks rose above the indicative target under the program. Part of this increase was linked to a decision to finance key food and fuel imports and ensure sufficient supply to the market as prices for these goods increased. Liquidity lending from the NBT to the commercial banking system continued to rise in the first two months of 2011, however, and we recognize the potential 
risk that such lending could pose to inflation, the exchange rate, and the NBT balance sheet. We are committed to bringing such lending under control, as discussed below, to ensure a path for money growth that is consistent with macroeconomic stability.

With respect to structural reforms, all benchmarks for the second half of 2010 have been met, albeit with small delays for two of the benchmarks. The audited financial statements for the NBT were published on its website in September. In early January, we submitted to parliament a revised NBT Law, as well as a Law on Insolvent Credit Institutions. We are grateful to the IMF and the World Bank, respectively, for technical assistance in drafting these two laws.

We also continue to move forward in increasing transparency in the state enterprise sector. The Roghun OJSC published its second quarterly report on financial flows and operations on the Ministry of Finance website in December 2010, and we expect to hold the first shareholder meeting in May 2011. Work continues on the audit of Roghun OJSC, but because of the need to first carry out a survey of work in progress, we request the rephasing of this benchmark from end-February 2011 until end-June 2011. In the meantime, however, we expect to publish the audited 2009 financial statement of Talco in the near future, and the audited financial statements for Talco Management by end June 2011 (a structural benchmark under the program).

We request a waiver for the non-observance of the continuous performance criterion on nonaccumulation of external payments arrears. These arrears, which were linked to two government guaranteed loans, were cleared in a relatively short period, and the most recent installment on one of these loans was paid in advance. We have also instituted a new pledge agreement imposing a penalty interest on arrears for this loan, and will expand this practice to other borrowers. We are also seeking to institute a new accounting system for guaranteed loans to prevent accumulation of new arrears, and will enhance communication between the government, borrowers, and creditors. We will in future also continue to restrict the use of government guarantees, and have also requested a Debt Management Performance Assessment (DEMPA) from the World Bank. The end result will be a substantial improvement in our ability to track and deliver on external obligations and a strengthening of public financial management.

Looking ahead, we remain committed to achieving the reforms outlined in the Memorandum of Economic and Financial Policies (MEFP) of November 9, 2010. In this context, two points in particular are worth highlighting. First, we are working to enforce the presidential order of August 2010 requiring investors to repay cotton loans as part of the strategy to recapitalize the NBT. As committed, we will also produce this year an agreed schedule of government injections into the NBT (a structural benchmark for end-June 2011). Second, we remain committed to producing a strategic plan to reform the tax regime - with a view to broadening 
the tax base, increasing tax revenue, and creating an environment conducive to private sector growth (a structural benchmark for end-September 2011).

In addition, and reflecting some of the problems noted above, we commit to the following measures:

- The recent surge in liquidity lending from the NBT to commercial banks will be contained and brought under tighter control in the course of the year. Future operations to finance imports for the strategic reserve will be handled through the budget. The remaining stock of liquidity loans will be reduced to ensure orderly money growth consistent with macroeconomic and price stability. The government will also refrain from directed lending.

- To protect the balance sheet of the NBT, better establish its role as a lender of last resort, and encourage development of an interbank market, applications for liquidity loans will receive greater scrutiny. The terms of these loans were tightened at the end of March 2011, by raising interest rates on liquidity loans to prevailing market rates. Strict observation of collateral requirements will also be enforced. The NBT will continue to work closely with the IMF on this issue.

- An action plan - consistent with IMF advice - to bolster supervision and strengthen the financial sector will be formulated and endorsed by the Board of the NBT by June 2011 (a structural benchmark). It will provide a sequenced process covering regulation, accounting of assets, provisions, and collateral, revaluation of these items, recognition of these changes in the balance sheet, and compliance with prudential regulations. Progress in implementing this plan will be monitored in coordination with the IMF.

- Subject to resource availability and with a view to strengthening commercial banks' balance sheets and enhance liquidity, the government bonds placed with commercial banks as part of the cotton debt resolution will be re-issued on market terms.

While recent data on macroeconomic performance are encouraging, we remain concerned about the recent surge in international food prices, and the potential impact on the poor. We ask the international community for assistance in this area, and look to the IMF and other IFIs for close support and coordination of measures to mitigate the impact of higher food prices on the most vulnerable segments of society.

We hereby request completion by the Executive Board of the fourth review under the ECF arrangement, and disbursement of the fifth loan totaling an amount equivalent to SDR 13.045 million. In parallel, we are seeking continued concessional support from other donors for the coming year to achieve the objectives laid out in the Poverty Reduction Strategy (PRS) 
covering the period 2010-12. For the fourth review under the ECF arrangement we request a waiver for nonobservance of the performance criterion on the non-accumulation of external payments arrears. We also request the modification of the quantitative performance criterion on net domestic assets for end-June 2011 and end-December 2011, as well as indicative targets, and structural benchmarks described in the attached tables, the MEFP of November 9, 2010, and modification to the attached TMU, to enable us to monitor progress in implementing our reform agenda.

The Government believes that the policies set forth in this letter and the MEFP are adequate to achieve the objectives of its program, but will take any further measures that may become appropriate for this purpose. We will consult with the Fund on the adoption of these measures and in advance of any revision to the policies contained in the MEFP, in accordance with the Fund's policies on such consultation. We intend to remain in close consultation with Fund staff and provide timely information necessary for monitoring economic developments and implementation of policies under the ECF arrangement. In addition, the Government stands ready to take any further measures that might be required to ensure that the overall objectives of the program are attained.

Finally, in continuing with our commitment to transparency, we hereby request that all program related documents, including this letter, be published on the IMF website.

Your Excellency, please accept my assurances of my highest consideration, $/ \mathrm{s} /$

Emomali Rahmon

President of the Republic of Tajikistan 
Table 1. Tajikistan: Quantitative Performance Criteria and Indicative Targets under the 2010 Extended Credit Facility (ECF) (In millions of somoni; unless otherwise indicated)

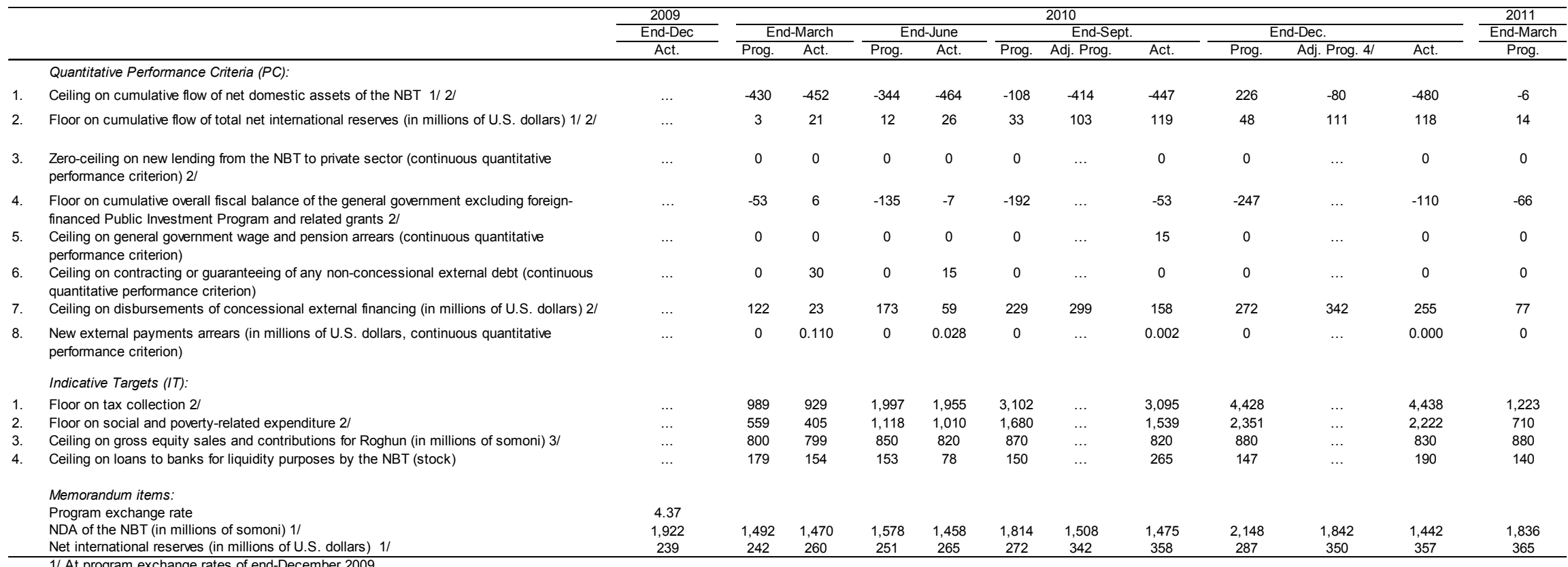

Net international reserves (in millions of U.S. dollars)

2/ Cumulative from January 1 of the year; performace criteria for end-June and end-December 2010, and indicative targets other dates.

$3 /$ Cumulative from January 1, 2010.

$4 /$ Floor on cumulative NIR is adjusted and revised. 
Table 2. Tajikistan: Quantitative Performance Criteria and Indicative Targets under the 2011 Extended Credit Facility (ECF)

(In millions of somoni; unless otherwise indicated)

\begin{tabular}{|c|c|c|c|c|c|c|c|}
\hline & & 2010 & & & 2011 & & \\
\hline & & End-Dec & & March & End-June & End-Sept. & End-Dec. \\
\hline & & Act. & Prog. 4/ & Prel. Proj. 5/ & Prog. & Prog. & Prog. \\
\hline & Quantitative Performance Criteria (PC): & & & & & & \\
\hline 1. & Ceiling on cumulative flow of net domestic assets of the NBT $1 / 2$ / & $\ldots$ & -6 & -8 & 120 & 210 & 328 \\
\hline 2. & Floor on cumulative flow of total net international reserves (in millions of U.S. dollars) $1 / 2$ / & $\ldots$ & 14 & 14 & 25 & 45 & 70 \\
\hline 3. & $\begin{array}{l}\text { Zero-ceiling on new lending from the NBT to private sector (continuous quantitative } \\
\text { performance criterion) } 2 /\end{array}$ & $\cdots$ & 0 & 0 & 0 & 0 & 0 \\
\hline 4. & $\begin{array}{l}\text { Floor on cumulative overall fiscal balance of the general government excluding foreign- } \\
\text { financed Public Investment Program and related grants } 2 /\end{array}$ & $\cdots$ & -66 & -66 & -134 & -208 & -297 \\
\hline 5. & $\begin{array}{l}\text { Ceiling on general government wage and pension arrears (continuous quantitative } \\
\text { performance criterion) }\end{array}$ & $\cdots$ & 0 & 0 & 0 & 0 & 0 \\
\hline 6. & $\begin{array}{l}\text { Ceiling on contracting or guaranteeing of any non-concessional external debt (continuous } \\
\text { quantitative performance criterion) }\end{array}$ & $\cdots$ & 0 & 0 & 0 & 0 & 0 \\
\hline 7. & Ceiling on disbursements of concessional external financing (in millions of U.S. dollars) 2/ & $\ldots$ & 77 & 77 & 154 & 231 & 308 \\
\hline 8. & New external payments arrears (continuous quantitative performance criterion) & $\ldots$ & 0 & 0 & 0 & 0 & 0 \\
\hline & Indicative Targets (IT): & & & & & & \\
\hline 1. & Floor on tax collection $2 /$ & $\ldots$ & 1,223 & 1,223 & 2,470 & 3,837 & 5,478 \\
\hline 2. & Floor on social and poverty-related expenditure $2 /$ & $\ldots$ & 710 & 710 & 1,421 & 2,131 & 2,841 \\
\hline 3. & Ceiling on gross equity sales and contributions for Roghun (in millions of somoni) 3 / & $\ldots$ & 880 & 880 & 880 & 880 & 880 \\
\hline 4. & Ceiling on loans to banks for liquidity purposes by the NBT (average per quarter) & $\ldots$ & 140 & 377 & 227 & 180 & 157 \\
\hline & $\begin{array}{l}\text { Memorandum items: } \\
\text { Program exchange rate }\end{array}$ & 4.40 & & & & & \\
\hline & NDA of the NBT (in millions of somoni) $1 /$ & 1,164 & 1,836 & 1,156 & 1,285 & 1,375 & 1,492 \\
\hline & Net international reserves (in millions of U.S. dollars) 1/ & 375 & 365 & 390 & 400 & 420 & 444 \\
\hline
\end{tabular}

2/ Cumulative from January 1 of the year; performance criteria for end-June and end-December 2011, and indicative targets for end-March and end-September.

3/ Cumulative from January 1, 2010.

4/ Valued at exchange rate of end-December 2009

5/ Reflects staff discussions with authorities during February 2011 mission. 
Table 3. Tajikistan: Structural Benchmarks for 2010

\begin{tabular}{l}
\hline Date \\
Rationale
\end{tabular}

Structural Benchmarks and Prior Actions for Third

Review

Issue a government order to require cotton investors to start paying principal (in equal installments) and interest on their outstanding debt to the NBT

Issue a tender for an audit of the 2008 and 2009 financial statements of Roghun OJSC by a reputable international firm.

Issue a tender for an external audit of Talco Management's 2008 and 2009 financial statements by a reputable international audit firm.

Roghun supervisory board report on a quarterly basis to the public about the sources and uses of funds, including detailed information on the contractors hired by Roghun OJSC, their owners, and the bidding process used to award all contracts.

\section{Structural Benchmarks for Second Half of 2010}

Publish the NBT's December 2009 audited financial statement together with the audit report on the NBT's website.

Submit to parliament a bankruptcy law for credit institutions.

Submit to parliament a draft NBT law consistent with IMF staff advice.

\begin{tabular}{|c|c|c|}
\hline End-June & $\begin{array}{l}\text { Key element of } \\
\text { NBT } \\
\text { recapitalization } \\
\text { strategy }\end{array}$ & $\begin{array}{l}\text { Met on August 12, } \\
2010\end{array}$ \\
\hline End-June & Transparency & $\begin{array}{l}\text { Met on June 30, } \\
2010 .\end{array}$ \\
\hline $\begin{array}{l}5 \text { working days } \\
\text { prior to Executive } \\
\text { Board Meeting }\end{array}$ & Transparency & $\begin{array}{l}\text { Met on November } 3 \text {, } \\
2010\end{array}$ \\
\hline $\begin{array}{l}5 \text { working days } \\
\text { prior to Executive } \\
\text { Board Meeting } \\
\text { and each quarter } \\
\text { thereafter }\end{array}$ & $\begin{array}{l}\text { Transparency } \\
\text { and } \\
\text { governance }\end{array}$ & $\begin{array}{l}\text { Met on November } \\
\text { 12, } 2010(\mathrm{Q} 1, \mathrm{Q} 2) \\
\text { Met on December } \\
24,2010(\mathrm{Q} 3) \\
\text { Met on March 30, } \\
2011 \text { (Q4) }\end{array}$ \\
\hline
\end{tabular}

End-September

Transparency

End-December

Strengthen the banking system

End-December

Enhance central bank governance
Met on January 4, 2011

Met on January 4,

Met on September 30, 2010 2011 
Table 4. Tajikistan: Structural Benchmarks for 2011

\begin{tabular}{|c|c|c|c|}
\hline & Date & Rationale & Status \\
\hline $\begin{array}{l}\text { Banks not meeting established prudential criteria to submit to } \\
\text { NBT for approval time-bound actions plans to become fully } \\
\text { compliant with these standards, including correct provisioning } \\
\text { for non-performing loans. }\end{array}$ & End-March & $\begin{array}{l}\text { Financial sector } \\
\text { stability }\end{array}$ & $\begin{array}{l}\text { Met on } \\
\text { March 31, } \\
2011\end{array}$ \\
\hline $\begin{array}{l}\text { Publish the audited financial statements of Roghun OJSC for } \\
2008 \text { and } 2009 \text { with the audit reports on the Ministry of } \\
\text { Finance's website. }\end{array}$ & End-June & Transparency & \\
\hline $\begin{array}{l}\text { Expand the number of large taxpayers under the Large } \\
\text { Taxpayer Inspectorate (LTI). }\end{array}$ & End-June & PFM / Revenue & \\
\hline $\begin{array}{l}\text { Issue a government resolution specifying a multi-year (2011- } \\
2018 \text { ) schedule for injections of capital from the government } \\
\text { into the NBT as part of the NBT recapitalization plan and in } \\
\text { line with IMF recommendations. }\end{array}$ & End-June & $\begin{array}{l}\text { NBT } \\
\text { recapitalization }\end{array}$ & \\
\hline $\begin{array}{l}\text { Publish the audited financial statements of Talco Management } \\
\text { for 2008-2009 together with the audit reports. }\end{array}$ & End-June & Transparency & \\
\hline $\begin{array}{l}\text { NBT Board to approve an action plan, in line with IMF } \\
\text { recommendations, for addressing weaknesses in the financial } \\
\text { sector. }\end{array}$ & End-June & $\begin{array}{l}\text { Financial sector } \\
\text { stability }\end{array}$ & \\
\hline $\begin{array}{l}\text { National Bank of Tajikistan to publish audited } 2010 \text { financial } \\
\text { statement }\end{array}$ & End-September & Transparency & \\
\hline Submit to cabinet a strategy for reform of the tax regime. & End-September & Revenue & \\
\hline $\begin{array}{l}\text { Fiscal risk statement related to condition of SOEs to be } \\
\text { introduced as part of the published } 2012 \text { budget document }\end{array}$ & End-December & SOE governance & \\
\hline
\end{tabular}




\section{Attachment II. Tajikistan: Memorandum of Economic and Financial Policies (MEFP) FOR 2009-12}

\section{November 9, 2010}

\section{INTRODUCTION}

1. This memorandum outlines economic and financial policies of the Government of Tajikistan for 2010-12, and augments President Rahmon's letter of intent and the memorandum of economic and financial policies dated May 20, 2010, focusing now on our policies for the remainder of 2010 and 2011. These policies are intended to serve as the basis for the ongoing IMF-supported program under the Extended Credit Facility (ECF).

1. Tajikistan now appears to be emerging from the global economic downturn of 2009, although the impact of external shocks continue to be felt in some sectors. Real economic growth rose to over 7 percent in the first half of 2010, with particularly strong performance in electricity production, construction, and trade and services. We expect real GDP growth to reach at least 5.5 percent for the year as a whole. Inward remittances have also rebounded, in line with the recovery in neighboring economies. Total inward remittances increased by about 25 percent year-on-year through June, providing welcome income support. Inflation has been subdued for most of the year, thanks to a benign global environment. However, we expect end-year inflation to reach about 9 percent due to the recent surge in wheat and wheat flour prices. Financial sector indicators have worsened-lagging the incipient recovery and reflecting continued difficulties in the external, agricultural, and state enterprise sectors.

2. In this environment, our program focuses on safeguarding macroeconomic and balance of payments stability, supporting the poor and vulnerable segments of society, moving ahead with key infrastructure projects to address Tajikistan's bottlenecks in the energy sector, and accelerating structural reforms, including by strengthening governance of public sector institutions and enhancing the role of the private sector.

3. We have reached understandings with IMF staff on a set of prior actions for the third review, and on quantitative performance criteria, indicative targets, and structural benchmarks for 2011. Our policy framework continues to build on the measures that we implemented during the Staff Monitored Program, and draw on more recent work, such as the special audit of the National Bank of Tajikistan (NBT), the 2007-08 Financial Sector Assessment Program, the safeguards assessment, and technical assistance in tax administration and public financial management.

4. Our macroeconomic policies are based the government's National Development Strategy for the period until 2015, and our Poverty Reduction Strategy (2010-12). In the short term, our program aims to maintain macroeconomic stability — which is a precondition for sustained high growth and poverty reduction. Structural reforms in financial, state-owned enterprise (SOEs), and agriculture sectors are designed to enhance the growth potential of our 
economy over the medium-term. In addition, we intend to move forward with key infrastructure projects in the energy sector. We believe that these reforms will give rise to sustained higher rates of economic growth, which will in turn make the biggest impact on poverty. In this context, we are committed to the principle that planned increases in bettertargeted social spending and associated recurrent costs be fully covered by revenue from tax, administrative, and public financial management reforms. Given limited fiscal space, we are working closely with the Donor Coordination Council to further streamline and prioritize the PRS.

\section{Macroeconomic Policies}

5. Within our overall macroeconomic policy framework, the construction of the Roghun hydropower plant (HPP) is of the highest strategic importance to address Tajikistan's energy deficit and thus lay the foundation for future growth and poverty reduction. This will be crucial to meet Tajikistan's growing energy needs, though additional generation capacity and significant maintenance on existing facilities is likely to be needed.

6. Construction of Roghun and its financing will impact our macroeconomic objectives in 2010 and beyond. The total cost of the project's first phase is estimated at around SM6 billion ( $\$ 1.4$ billion, or 24 percent of 2010 GDP) of which around $\$ 600$ million would be imports. We have established a joint stock company (Roghun OJSC) with an authorized capital of SM 6 billion, 75 percent of which will be owned by the government. Beginning in January 2010, we offered equity to the public of up to 25 percent of the shares (SM 1.5 billion). Initial equity purchases and contributions yielded SM 800 million through March 2010. The Roghun advertising campaign was subsequently suspended in mid April. Since that time, a very small level of contributions have continued to accumulate (in the form of deposits of Roghun OJSC with commercial banks and a special treasury subaccount at the NBT), bringing the total level of shares sold to SM 820 million by end-June. We expect total shares sold to remain below SM 880 million by the end of the year. Through end-August, some 205 million of these deposits had been used to finance work on the project. Once the results of a techno-economic, social and environmental impact assessment of the Roghun project are available, we will revisit our financing strategy in close consultation with Fund and World Bank staff, and intend to request the World Bank to lead an international financing consortium.

7. A supervisory board, headed by the prime minister and consisting of government officials as well as representatives of private sector shareholders, oversees all financial aspects of the Roghun OJSC. The first quarterly report to the public about the sources and uses of funds, including detailed information on the contractors hired by Roghun OJSC, their owners, and the bidding process used to award all contracts will be published on the Ministry of Finance's website as of November 2010 (benchmark for end-June 2010). We tendered an audit of Roghun OJSC's 2008 and 2009 financial statements to a reputable international accounting firm at end-June (benchmark for end-June 2010). However we encountered 
delays in finding a suitable auditor, and therefore now expect the first audit to be published by end-February 2011 (benchmark), rather than end-December 2010, as originally envisioned. Regular audits by a reputable international firm will continue on an annual basis. A first shareholder meeting will be convened by end-February 2011. In this context, we will abide by the principles set out in the OECD Guidelines on Corporate Governance of StateOwned Enterprises. In particular, we commit to equitable treatment of all shareholders and will, from October 2010 onwards, take all measures to enact registration of all minority shareholders and give them the opportunity to participate in major corporate decisions. Once profits allow, Roghun OJSC will make dividend payments to all shareholders.

8. Against this background, we have reached an understanding with IMF staff on macroeconomic policies for the remainder of 2010 and 2011. In the fiscal area, we will adhere to the deficit target of 1 percent of GDP for 2010 (excluding the externally financed public investment program - PIP) previously agreed with the IMF. For 2011, we will seek to achieve GDP growth of at least 5 percent, and limit year-end inflation to 7 percent. Given the need to balance pressing social and development needs against limited domestic resources, we intend to target a deficit of 1 percent of GDP. This will help to ensure that the economic recovery does not falter, and that the government can modestly increase social spending. We will protect social spending from expenditure cuts in case of unexpected revenue shortfalls, and use any additional donor grants (if forthcoming) for spending in this area. We will also closely monitor the overall deficit (including the externally financed PIP) closely to ensure debt sustainability. Monetary policy will continue to target reserve money growth as the nominal anchor, while we will maintain our flexible exchange rate regime. We aim to raise reserve cover from its current low levels by further accumulating net international reserves (NIR). In this context, the NBT will limit its interventions in the foreign exchange market to smoothing excess volatility.

9. In the medium term, we hope that a more favorable international environment will pave the way toward higher growth and external balance. In these circumstances we hope to significantly strengthen our international reserves position, and target a reserves coverage of 2 months of imports by 2015. In the fiscal area, we will balance the pressing spending needs in the social and infrastructure areas, while broadly aiming for overall fiscal balance (excluding PIP), with a view to keeping government debt below the ceiling of 40 percent of GDP that we have set in our debt strategy. In this context, we are committed to strengthen public debt management and reporting by public enterprises. Our strategy also addresses the fiscal impact of the cotton debt resolution (paragraph 13).

\section{STRUCTURAL REFORMS FOR 2010-2011}

\section{A. Monetary and Financial Sector Reforms}

10. A safeguards assessment update of the NBT was completed in mid-2010. The findings indicated that initial steps have been taken to address the risks identified by the 
special audit on cotton sector financing, but that considerable safeguards risks at the NBT remain. Both the accounting and the organizational structure are still fragmented, and due to the weak internal audit function and an absence of any external independent oversight, access to broad and complete information has been restricted. Consequently, there is a need to further enhance data systems and the transparency of operational integrity. Restoring the credibility of the central bank and building the required capacity in key functions, such as internal audit and financial reporting will require more time. Under our NBT action plan (shown in Table 1) we are implementing the main recommendations of the special audit of the NBT, as well as recommendations of the safeguards assessment A task force, chaired by a non-executive Board Director, to assess progress on these reforms on a semi-annual basis was appointed in June 2010. To ensure transparency and accountability, we are also fully committed to semi-annual external reviews of the NBT's net international reserves.

11. Amendments to the NBT Law in 2009 addressed key shortcomings that needed immediate action. With the objective of bringing the law in its entirety in line with international practices, we initiated an internal review in July 2010 and have also received input and recommendations from an IMF technical assistance mission in October. We intend to submit to parliament a draft NBT law consistent with Fund staff advice by end-December 2010 (benchmark), with a view to adopting the law by June 2011.

12. Our NBT recapitalization strategy balances the NBT's needs (strong balance sheet, instruments for monetary policy) and the government's interests (minimize fiscal costs). As part of the strategy, the government has resumed servicing the recapitalization bonds held by the NBT, and transferred deposits from the Multilateral Debt Relief Initiative (MDRI) from government accounts to the NBT. The NBT has in turn resumed paying interest on government deposits. In addition, the government will make annual capital injections into the NBT over the coming eight years, starting in 2011. A presidential decree was issued in August 2010 requiring cotton investors to begin paying quarterly principal (in equal installments) and interest on their outstanding debt to the NBT (benchmark for end-June 2010). Bilateral agreements with 10 of the 12 investors have already been signed and we expect payments to begin by end-September. To contribute to its recapitalization, the NBT continues to work on improving its reserve management practices. An updated strategy, taking into account progress to date and changes in market conditions, will be completed by end-2010 with IMF assistance - the recommendations of which will be accounted for in the official 2011 budget.

13. In its monetary policy operations, the NBT will continue to refrain from issuing new credits to the private sector, except for liquidity purposes or in cases of bank distress or failure (lender of last resort). All lending to commercial banks and nonbank financial institutions is restricted to the NBT's short-term liquidity facility. In consultation with IMF staff, we also adopted in mid-year a regulation establishing a remunerated deposit facility with the NBT to serve as the only deposit facility available to banks to increase the NBT's flexibility in managing its excess liquidity. 
14. We seek to strengthen Tajikistan's financial sector with a view to reinvigorating private sector credit growth. The NBT monitors closely potential vulnerabilities in the banking system, paying close attention to banks' loan classification-including through onsite visits - and the Uniform Bank Performance Reports. Banks' asset quality deteriorated in 2010, impeding their scope for credit extension. Financial sector indicators have continued to show weaknesses, with a small number of banks consistently violating prudential rules (including on single party exposure limits and reserve requirements). To address these issues, the Ministry of Finance issued in May 2010 some \$90 million (SM350 million) in recapitalization bonds (as part of the cotton debt resolution) to commercial banks to improve their asset quality. When resources permit, we will review the terms of these bills with a view to enhancing their liquidity and value as collateral. By end-December the NBT will also submit to parliament a bankruptcy law for credit institutions (benchmark) in consultation with IMF staff, thereby filling a gap in our commercial bank legislation. The NBT will also require those banks not in compliance with prudential rules by end-March 2011 to develop and submit to the NBT for approval time bound plans to become fully compliant with all standards (benchmark), including correct provisioning for non-performing loans. We are also working with the World Bank to establish an appropriate anti-money laundering and counterterrorism financing framework (AML/CFT), and will submit an AML/CFT law to parliament by end-December 2010 .

\section{B. Reforms in the Fiscal Area}

15. With assistance from the World Bank, we continue strengthening the civil service, and the health, and education sectors. In the health sector, this involves allocating resources in an asymmetric fashion favoring primary health care. In education, we are moving ahead with a per capita funding pilot system. In this context, we are working toward a competitive and affordable civil service wage system. We raised the minimum wage and pension in July, and in October raised public sector salaries in the context of introducing a new grade scale at five pilot government agencies. A new health insurance law has been passed that plans, over the medium-term, to introduce mandatory universal health insurance. We are also preparing a new pension law that seeks to reform the pay-as-you-go and the fully funded pillar, and generate an actuarially balanced system for migrant workers with pension entitlements. Implementation of these laws will be postponed until they have been fully costed, and integrated into our medium-term budget framework, and their poverty and social impact assessed.

16. We seek to moderately raise the revenue-to-GDP ratio over time to create space for pressing spending needs. Based on recommendations from the IMF and other donor organizations we have submitted a proposal to the cabinet for a tax administration reform strategy to be implemented during 2011-15, with a view to building capacity in tax administration and contributing to the improvement of the quality of tax administration services and better collection of budget revenue. This includes an initiative to increase the number of taxpayers covered by the Large Taxpayer Inspectorate (LTI) by June 2011 
(benchmark). We have also prepared an initial inventory of existing tax and customs exemptions, and an assessment of their costs, and submitted to cabinet a proposal for reform of the exemptions regime. For 2011, we intend to undertake a review of tax policy, with a view to formulating a strategy for reform of the tax regime (benchmark) and decreasing our reliance on non-tax revenues. We will be asking the IMF, the World Bank, and other international financial institutions for technical assistance in these areas.

17. We are also pursuing steps to further enhance public financial and debt management. In this context, our public financial management strategy aims at the eventual introduction of a full Treasury Single Account (TSA) system at the Republican level and implementation of an electronic financial management information system. We have also adopted in 2010 a law on internal audit and state financial control. A registry of the gold and precious metals held by the Ministry of Finance has been completed, and these assets will be transferred to the NBT balance sheet as part of international reserves before the end of 2010. We are committed to prudent debt management, and will restrict our external borrowing to loans on concessional terms. To avoid potential problems vis-à-vis the requirements under the program, we are strengthening coordination with IMF staff to ensure that an appropriate level of concessionality is achieved for all new loans.

\section{State-Owned Enterprises, Agriculture, and Data}

\section{State-Owned Enterprises}

18. We are taking steps to address the problem of arrears in SOEs and put them on a sound financial footing. Some arrears reflect structural deficits in SOEs, others nonpayment of dues from government entities. Arrears remain a serious problem that could potentially jeopardize macroeconomic stability. We seek to address these problems urgently and ensure that these firms are subject to financial discipline going forward. For the near-term, we have ensured that the 2011 budget includes sufficient resources for all spending agencies to remain current on their obligations. Looking ahead, to enhance transparency and highlight any risks to public finance, we intend to complete a fiscal risk assessment report as part of the draft 2012 budget (benchmark).

19. The SOE Supervision Unit is making progress to becoming fully operational, with the help of the European Commission and IMF technical assistance. Hiring and retaining qualified staff remains difficult, however. The unit has assessed the financial performance of SOEs for 2009, and their 2010 financial plans. The unit has also prepared and published reports on SOE performance that are also published on the Ministry of Finance's website. By June 2011, all SOE's subject to review by the SOE unit (Ministry of Finance) will be required to publish 2010 financial statements and results of external audits conducted in line with accepted standards of auditing on the Ministry of Finance website. We will be looking to the international community for technical assistance to support these efforts. 
20. Tajikistan Aluminum Company (Talco) has undergone an external audit of its 2006-08 financial statements, and the audit report and the financial statements together with the audit opinion have been published on the company's website (benchmark for endDecember 2009). Talco Management Company will soon issue a tender for an external audit of Talco Management's 2008 and 2009 financial statements by a reputable international audit firm (benchmark for end-June 2010).

21. The second-largest SOE, Barki Tajik, will—with World Bank support-continue electricity tariff adjustments in order to achieve cost recovery by end-2011. In the meantime, the government will continue to work with donors to improve the social mitigation mechanism to ensure that the most vulnerable segments of the population have access to a basic minimum of energy services. Following up on the external audit of its 2007 accounts, Barki Tajik will continue to work with the World Bank on improving its financial management. An improvement in collection of payment arrears will be essential.

22. For the purpose of disclosure of beneficial ownership of all companies registered with the Ministry of Finance's agency for securities, we finalized the database of beneficial ownership of all companies listed with the agency, and published it on the ministry's website.

\section{Agriculture}

23. In June 2009 we adopted an action plan to resolve the cotton debt problem, and are proceeding with its implementation. All farm debt accumulated as of January 1, 2008, and all interest accrued on that stock since that time has been written off. Certificates legally discharging farmers from debt obligations to investors were distributed. As part of the action plan we encouraged all banks to apply the Tajikistan Agricultural Financing Facility methodology, developed by the European Bank for Reconstruction and Development, for the government financing scheme for the agriculture sector in 2010. In light of fiscal constraints, budgetary resources available for lending to the agriculture sector will be limited to resources that are paid back in 2011, and over the medium-term we will be looking to phase out budgetary support in this area. A precondition for having a private-sector led financing mechanism will be the ability to use land-use rights as collateral. We are working closely with the World Bank, Asian Development Bank, and other donors on the implementation of the action plan. We are also seeking donor financing for the agriculture sector to ensure that farmers have sufficient access to credit under the new mechanisms being developed. We hope our recent proposal for financing under Global Agriculture and Food Security Fund (GAFSP) will receive favorable support from the donor community.

\section{Data}

24. We plan to strengthen our national accounts and price statistics, with technical assistance from the regional IMF statistics advisor, who will coordinate closely with the STATCAP project led by the World Bank. 
25. We will also continue to strengthen our debt data management framework, including by completing an inventory of government domestic debt and domestic and external debt of SOEs. This information will be published, together with a report on government and government-guaranteed external debt, in the 2011 budget documents. In addition, the NBT continues to strengthen the monitoring system of private external debt, and began publishing these data on the NBT website on a semi-annual basis starting as of June 2010 - sharing this data on a quarterly basis with the Ministry of Finance.

\section{Program Monitoring}

26. We will continue to monitor progress in implementing the program through quantitative performance criteria and indicative targets, as well as prior actions, and structural benchmarks set for 2010 and 2011. These are listed in the tables attached to the letter of intent. The technical memorandum of understanding which is also attached to this letter defines the quantitative targets of the program and their adjustors, and specifies reporting requirements. Completion of the fourth review under the ECF arrangement — which is envisaged for March 15, 2011-will require observance of the quantitative performance criteria for end-December 2010 and other relevant performance criteria, completion of the fifth review-which is envisaged for September 15, 2011- will require observance of the quantitative performance criteria for end-June 2011 and other relevant performance criteria, and completion of the sixth review - which is envisaged for March 16, 2012 - will require observance of the quantitative performance criteria for end-December 2011 and other relevant performance criteria. 
Table 1: NBT Reform Action Plan

\begin{tabular}{|c|c|c|}
\hline Reform & Timing & Status \\
\hline \multicolumn{3}{|l|}{ GOVERNANCE } \\
\hline Close down the Cotton Debt Department at the NBT. & June 2009 & Done \\
\hline $\begin{array}{l}\text { Appoint the NBT Board for a fixed term with } 3 \\
\text { non-executive members. }\end{array}$ & June 2010 & Done \\
\hline $\begin{array}{l}\text { Establish NBT Board Committees, such as an audit } \\
\text { committee, chaired by a non-executive member of the NBT } \\
\text { Board. }\end{array}$ & June 2010 & Done \\
\hline $\begin{array}{l}\text { Create and publish on the NBT's website a register of } \\
\text { commercial interests of NBT Board members and top } \\
\text { management }\end{array}$ & June 2010 & Done \\
\hline $\begin{array}{l}\text { Develop proposals to restructure the NBT' organizational } \\
\text { set up }\end{array}$ & December 2010 & \\
\hline $\begin{array}{l}\text { A draft revised central bank law substantially compliant } \\
\text { with the recommendations of Fund staff should be } \\
\text { approved by the President of the Republic and submitted to } \\
\text { Parliament for enactment. }\end{array}$ & December 2010 & \\
\hline \multicolumn{3}{|l|}{ AUDITING } \\
\hline $\begin{array}{l}\text { External audits of financial accounts for FY ending April } \\
2009 \text { and for the } 8 \text { months ending December 31, } 2009 \text { to } \\
\text { be completed. }\end{array}$ & $\begin{array}{l}\text { September } \\
2010\end{array}$ & Completed \\
\hline $\begin{array}{l}\text { Continue semi-annual NIR reviews by an international audit } \\
\text { firm at test dates under the ECF arrangement. Such } \\
\text { reviews should be completed before the IMF Board } \\
\text { meeting and the TOR for the reviews should be adapted as } \\
\text { needed to ensure that (i) the auditor attends vault counts } \\
\text { on the relevant test date; (ii) emerging issues are } \\
\text { addressed; and (iii) previous recommendations are being } \\
\text { addressed. }\end{array}$ & $\begin{array}{l}\text { Prior action for } \\
\text { the Board } \\
\text { meeting }\end{array}$ & $\begin{array}{l}\text { KPMG completed } \\
\text { end-June NIR } \\
\text { review in July. }\end{array}$ \\
\hline $\begin{array}{l}\text { Publish on its external website in a dedicated section the } \\
\text { financial statements and audit opinion within } 1 \text { month from } \\
\text { completion of the audit, also including all past audit reports. }\end{array}$ & Continuous & Completed \\
\hline
\end{tabular}




\begin{tabular}{|c|c|c|}
\hline Reform & Timing & Status \\
\hline $\begin{array}{l}\text { Develop an internal regulation to define a formal policy for } \\
\text { the selection and appointment of its external auditor. The } \\
\text { policy should stipulate: (i) the composition of the selection } \\
\text { committee, including participation by non-executive Board } \\
\text { members; (ii) criteria for making the selection; (iii) a timeline } \\
\text { for the tendering, bidding and appointment, ensuring the } \\
\text { contracting of the external audit not later than } 3 \text { months } \\
\text { before the year-end; and (iv) multi-year audit contracts. }\end{array}$ & $\begin{array}{l}\text { September } \\
2010\end{array}$ & Done \\
\hline $\begin{array}{l}\text { Outsource-through a formal tendering process-to an } \\
\text { external consulting firm the internal audit of the activities of } \\
\text { (i) the international relations department, including foreign } \\
\text { exchange lending and liquidity support; (ii) the domestic } \\
\text { lending and liquidity support activities; and (iii) the } \\
\text { management of foreign currency vault operations at } \\
\text { headquarters. Ensure that external consultant contributes } \\
\text { to capacity building in the Internal Audit Department. }\end{array}$ & April 2010 & $\begin{array}{l}\text { Done; an external } \\
\text { consultant } \\
\text { "International } \\
\text { Auditing Company, } \\
\text { Ltd." was selected. }\end{array}$ \\
\hline $\begin{array}{l}\text { Plan and organize an external quality assurance review of } \\
\text { the NBT's Internal Audit Department by certified experts on } \\
\text { its compliance with Institute of Internal Auditors (IIA) } \\
\text { standards. }\end{array}$ & June 2011 & \\
\hline ACCOUNTING AND OPERATIONS & & \\
\hline $\begin{array}{l}\text { Create a new base of the NBT balance sheets and } \\
\text { continuously monitor their conformity with analytical data }\end{array}$ & June 2009 & $\begin{array}{l}\text { Recommendations } \\
\text { of special audit of } \\
\text { the NBT and } \\
\text { end-December } \\
2008 \text { NIR audit } \\
\text { incorporated. } \\
\text { Revised balance } \\
\text { sheet presented as } \\
\text { part of regular } \\
\text { annual audit. }\end{array}$ \\
\hline $\begin{array}{l}\text { Keep full records of adjustments made with regard to } \\
\text { audited financial reports, and keep full records to confirm } \\
\text { the data that the IMF publishes in its reports }\end{array}$ & Continuously & \\
\hline $\begin{array}{l}\text { Increase the number of sudden checks of cash available in } \\
\text { the NBT's head office and regional branches. }\end{array}$ & Continuously & \\
\hline Develop a mechanism to transfer and share information & Continuously & \\
\hline
\end{tabular}




\begin{tabular}{|l|l|l|}
\hline \multicolumn{1}{|c|}{ Reform } & Timing & \multicolumn{1}{|c|}{ Status } \\
\hline $\begin{array}{l}\text { between departments on any reclassification of items in the } \\
\text { NBT's accounting balance sheet for the purpose of } \\
\text { compiling the monetary analysis. }\end{array}$ & \\
\hline $\begin{array}{l}\text { Establish a register of the gold bars held in the NBT vaults, } \\
\text { including gold owned by the Ministry of Finance. This } \\
\text { register must include details on the serial number of the } \\
\text { gold bars and the ownership. This register must be } \\
\text { included in the scope of the NIR review, starting with the } \\
\text { end-December 2009 test date. }\end{array}$ & March 2010 & $\begin{array}{l}\text { Registry of gold } \\
\text { was completed in } \\
\text { August 2010. }\end{array}$ \\
\hline $\begin{array}{l}\text { Take measures to create a centralized accounting system } \\
\text { of the NBT by transferring all accounting functions to } \\
\text { relevant departments and introduce software for centralized } \\
\text { recording of transactions done by the NBT's regional } \\
\text { branches. }\end{array}$ & June 2010 & $\begin{array}{l}\text { Requesting } \\
\text { technical } \\
\text { assistance }\end{array}$ \\
\hline $\begin{array}{l}\text { Include the issue of accounting and monitoring of the NBT } \\
\text { balance sheet items in daily meetings of the working group. } \\
\text { Include representatives of the internal audit and accounting } \\
\text { into the working group }\end{array}$ & $\begin{array}{l}\text { Strengthen cash management by setting up basic } \\
\text { structures which assure the segregation of duties between } \\
\text { the front-office, back-office and accounting functions in } \\
\text { order to mitigate operational risks. }\end{array}$ & \\
\hline
\end{tabular}




\section{AtTaChment III. TaJikistan: TeChnical Memorandum of Understanding April 19, 2011}

\section{INTRODUCTION}

1. This memorandum defines the quantitative performance criteria and the indicative targets and relative adjustors, and establishes the content and frequency of the data to be provided to IMF staff for the program monitoring relating to the program supported by an arrangement under the Extended Credit Facility (ECF) — which replaced the existing three-year Poverty Reduction and Growth Facility (PRGF) arrangement following the entry into force of the Executive Board's decision of July 2009-under the request in the authorities' Letter of Intent dated April 19, 2011.

\section{Quantitative Performance Criteria}

\section{A. Definitions and Concepts}

2. Test dates. Quantitative performance criteria are set semi-annually starting December 31, 2010 through December 31, 2011, and are to be met at the end of each period unless otherwise specified.

3. National Bank of Tajikistan (NBT). The NBT is the central bank of the country responsible for the formulation and implementation of monetary policy. For the purpose of the program, NBT includes all its central and regional offices.

4. General government. For the purpose of the program, "general government" includes the republican government, local (including municipal) governments, and the agencies included in the administrative classification of the budget. It excludes all other agencies not specifically listed, including but not limited to Barki Tajik and Talco.

5. Foreign-financed PIP and related grants. The foreign financed PIP is a program of investments in infrastructure and social sectors agreed by the general government of Tajikistan and its donors (including but not limited to international financial organizations). The program is fully financed by related grants and loans, and does not involve any additional financing commitment from the general government of Tajikistan. Related grants are grants provided by the donors financing the PIP for financing of projects included in the PIP.

6. Domestic arrears are defined as the general government expenditure that have not been paid after coming due as determined in the State Budget of the Republic of Tajikistan and other government documents regulating the execution of the Budget for ten business days. 
7. Concessional and nonconcessional debt. Concessional debt is defined as debt with a grant element equivalent of 35 percent or more. The grant element of a debt is calculated using the commercial interest reference rates (CIRRs) plus a margin at the time of its contracting. For debts of an original maturity of 15 years or more, the average CIRR over the last 10 years will be used, while the average of CIRRs of the preceding six-month period will be used to assess the concessionality of debts with original maturities of less than 15 years. To the 10-year and 6-month averages of CIRRs, the following margins will be added: 0.75 percent for repayment periods of less than 15 years; 1 percent for 15-19 years; 1.15 percent for 20-29 years; and 1.25 percent for 30 and more years. In general, the grant element is calculated as value of the loan minus present discounted value of future payments over the loan value (multiplied by 100). Present discounted value is sum of all future discounted payments (both amortization and interest), where the discount rate corresponds to the CIRR mentioned above. Nonconcessional debt is defined as debt without a grant element or with a grant element of less than 35 percent. The debt refers also to commitments contracted or guaranteed and for which value has not been received. The calculation is performed by the authorities and verified by the IMF based on the data provided by the authorities.

8. Valuation changes (program exchange rates). For program monitoring, U.S. dollar-denominated components of the general government's and the NBT's balance sheets will be valued at the program exchange rate (SM4.4031 = US\$1.00; official exchange rate as of December 31, 2010). Other foreign currency denominated items will be valued at the respective cross rates between the program exchange rate of the U.S. dollar and current official exchange rates of the U.S. dollar against those currencies as of December 31, 2010. The SDR components will be valued at the program SDR exchange rate SDR $=\$ 1.54003$ (December 30, 2010). Official gold holdings shall be valued at US\$1,410.25 per troy ounce (December 31, 2010).

\section{B. Quantitative Performance Criteria and Indicative Targets}

\section{Quantitative Performance Criterion 1: Ceiling on a cumulative flow of net domestic assets of the NBT for the year.}

9. Definition. For the purpose of the program, net domestic assets (NDA) of the NBT are defined as reserve money at program exchange rates minus net foreign assets at program exchange rates of the NBT. The cumulative flow of NDA for the year is defined as a difference between end-of-period balances for a period under evaluation and the preceding end-of-the year balance, unless otherwise specified. Reserve money (RM) at program exchange rates is composed of currency in circulation (CC), required reserves (RR), other bank reserves (OBR), and deposits of nongovernmental nonbanks with the NBT (DNGNB). The value of the net foreign assets at program exchange rates of the NBT is calculated as the difference between NBT's claims on nonresidents and its liabilities to nonresidents. The 
NBT's NDA comprise the following assets and liabilities: net credit to the general government, net claims on banks, credit to the economy, and other items net (OIN). OIN includes the foreign exchange revaluation and capital accounts of the NBT.

10. Adjustor for changes in reserve requirement ratio. The ceiling on a cumulative flow of NDA of the NBT for the year will be adjusted upwards (downward) when the required reserve rates (rr) on deposits in local and/or foreign currency (DB) are increased (decreased), resulting in a corresponding increase (decrease) of reserve money (RM).

NDA before RR change: NDA=RM-NFA

$\mathrm{RM}=\mathrm{CC}+\mathrm{RR}+\mathrm{OBR}+\mathrm{DNGNB}$ where:

$\mathrm{RR}=\mathrm{rr} * \mathrm{DB}$

DB - deposit base

rr - required reserve rate

Define: $d r r$ - change of required reserve rate.

DB - deposit base used for calculation of required reserves

drr*DB - amount of upward (if drr $>0$ ) or downward (if drr $<0$ ) adjustment in $\mathrm{RM}$

NDA after RR change NDA=RM (+/-)drr*DB-NFA.

11. Adjustor for Ministry of Finance gold holdings. The cumulative NDA flow is adjusted downward (upward) for any deposit (withdrawal of deposit) of Ministry of Finance's gold holdings with the NBT during the program period.

\section{Quantitative Performance Criterion 2: Floor on a cumulative flow for the year of total net international reserves (in millions of U.S. dollars).}

12. Definition. Total net international reserves of the NBT are defined as the difference between total gross international reserves of the NBT and total reserve liabilities of the NBT. Total gross international reserves of the NBT are defined to include NBT's holdings of monetary gold (defined as gold of London good delivery quality), including monetary gold owned by the Ministry of Finance, SDRs, convertible currencies in cash or in nonresident financial institutions that are readily available and any reserve position at the IMF. Also included are holdings of foreign currency-denominated securities issued by governments or central banks of OECD member states. Excluded are changes in the level of gross foreign reserves that arise from capital subscriptions in foreign financial institutions, non-liquid assets of the NBT, convertible currency denominated claims on domestic banks and other residents, assets in nonconvertible currencies, foreign assets pledged as collateral or 
otherwise encumbered and the net forward position, if any (defined as the difference between the face value of foreign currency denominated NBT off balance sheet claims on nonresidents and foreign currency obligations to both residents and nonresidents). Reserve liabilities of the NBT are defined as liabilities outstanding to the IMF and liabilities of the NBT to nonresidents with an original maturity of up to and including one year. A cumulative flow for the year of total net international reserves (in millions of U.S. dollars) is defined as a difference between the end-of-period balances for the period under evaluation and the preceding end-of-the year balance, unless otherwise specified.

13. Adjustor for conversion of nonmonetary gold into monetary gold. The cumulative NIR flow will be adjusted upward by the amount of nonmonetary gold held by the NBT that is converted to monetary gold, and the amount of nonmonetary gold held by the Ministry of Finance that is converted to monetary gold and transferred to the reserve holdings of the NBT.

\section{Quantitative Performance Criterion 3: Zero ceiling on new lending and guarantees from the NBT to private sector (continuous quantitative performance criterion).}

14. Definition. New lending from the NBT to the private sector is defined as loans extended by the NBT to domestic commercial banks, credit unions, credit associations, and microfinance organizations with a maturity of more than three months, and loans extended by the NBT to other domestic nonbank financial institutions or any other domestic entity other than the general government. Short-term liquidity loans to domestic commercial banks, credit unions, credit associations, and microfinance organizations with a maturity of up to three months are not included under this definition. Guarantees are defined as any guarantee extended by the NBT of principal or debt service payment for debt issued or contracted by private sector entities.

Quantitative Performance Criterion 4: Floor on the cumulative overall fiscal balance of the general government excluding foreign-financed PIP and related grants.

15. Definition. The overall fiscal balance of the general government is defined from below the line on a cash basis as the negative sum of:

a. the change in net claims on the general government of the NBT: net claims on the general government of the NBT is defined as the net position of NBT loans and advances to the general government, NBT holdings of government securities (excluding treasury bills issued as part of the NBT recapitalization process), bank restructuring costs, and all deposits of the general government with the NBT (excluding the Ministry of Finance's gold holdings), counterpart deposits (which reflect balance of payments and/or general budget support from international financial institutions and other donors), and the privatization account (where proceeds from the privatization of state property are held); 
b. the change in net claims on the general government of the rest of the domestic banking system: net claims on the general government of the rest of the domestic banking system are defined to include the net position of the general government with respect to other domestic commercial bank assets (loans, overdrafts, cash advances, holdings of treasury bills or other securities) and liabilities (deposits, etc.). Treasury bills issued to commercial banks as part of the cotton debt resolution are excluded;

c. the change in net claims on the general government of domestic nonbank institutions and households: net claims on the general government of domestic nonbank institutions and households are defined as treasury bills, bonds or other government securities held by nonbank institutions and households (including nonresidents and nonresident financial institutions), plus any other liabilities of the general government to domestic nonbank institutions or households;

d. the change in net foreign liabilities of the general government: net foreign liabilities of the general government are defined as government debt to foreign sovereigns, and foreign financial and nonfinancial institutions. For this purpose, net foreign liabilities exclude liabilities that arose in the context of the externally financed PIP;

e. gross proceeds from the privatization of state property: gross proceeds from the privatization of state property are defined as all receipts originating from the sale of the general government property; and

f. the change in gross arrears of the general government: gross arrears refer to domestic or external arrears.

All changes will be calculated as the difference between end-of-period stocks, net of any valuation changes resulting from currency movements.

\section{Quantitative Performance Criterion 5: Ceiling on general government wage and pension arrears (continuous quantitative performance criterion).}

16. Definition. Arrears on general government and pensioners' pensions are defined as any shortfall in monthly disbursements of wages and pensions. These payments are defined as overdue if they have come due at the end of the month and remain unpaid for ten business days thereafter. To allow monitoring of the above defined arrears the government will provide data on actual wage payments, including a breakdown by local governments, as part of the monthly budget execution statements submitted to the IMF staff. The Agency on Social Protection and Pensions will provide quarterly reports and statements of their operations. 


\section{Quantitative Performance Criterion 6: Ceiling on contracting or guaranteeing of any nonconcessional external debt (continuous quantitative performance criterion).}

17. Definition. The definition of debt, for the purposes of the program, is set out in Executive Board Decision No. 12274, Point 9, as revised on August 31, 2009 (Decision No. 14416-(09/91); see below) and also includes commitments contracted or guaranteed and for which value has not been received. The debt limits apply to short-, medium-, and long-term debt contracted by the general government of Tajikistan, the National Bank of Tajikistan, and any other agency acting on behalf of the government, including but not limited to state-owned banks and state-owned enterprises that can issue external debt without a government guarantee.

\section{The definition of debt set forth in point No. 9 of the guidelines as revised on} August 31, 2009 reads as follows: "(a) For the purpose of this guideline, the term "debt" will be understood to mean a current, i.e., not contingent, liability, created under a contractual arrangement through the provision of value in the form of assets (including currency) or services, and which requires the obligor to make one or more payments in the form of assets (including currency) or services, at some future point(s) in time; these payments will discharge the principal and/or interest liabilities incurred under the contract. Debts can take a number of forms, the primary ones being as follows: (i) loans, i.e., advances of money to the obligor by the lender made on the basis of an undertaking that the obligor will repay the funds in the future (including deposits, bonds, debentures, commercial loans and buyers' credits) and temporary exchanges of assets that are equivalent to fully collateralized loans under which the obligor is required to repay the funds, and usually pay interest, by repurchasing the collateral from the buyer in the future (such as repurchase agreements and official swap arrangements); (ii) suppliers' credits, i.e., contracts where the supplier permits the obligor to defer payments until some time after the date on which the goods are delivered or services are provided; and (iii) leases, i.e., arrangements under which property is provided which the lessee has the right to use for one or more specified period(s) of time that are usually shorter than the total expected service life of the property, while the lessor retains the title to the property. For the purpose of the guideline, the debt is the present value (at the inception of the lease) of all lease payments expected to be made during the period of the agreement excluding those payments that cover the operation, repair or maintenance of the property. (b) Under the definition of debt set out in point 9 (a) above, arrears, penalties, and judicially awarded damages arising from the failure to make payment under a contractual obligation that constitutes debt are debt. Failure to make payment on an obligation that is not considered debt under this definition (e.g., payment on delivery) will not give rise to debt."

19. External debt limits apply to the contracting or guaranteeing of new nonconcessional short-term external debt (with an original maturity of up to and including one year), and to the contracting or guaranteeing of new nonconcessional medium- and long-term external debt (with original maturities of more than one year). 
20. Exclusions from the external debt limits. Loans contracted for debt rescheduling or refinancing if the terms of the new loan are more favorable will be excluded from the debt limits. IMF credit is excluded from the external debt limits. The rollover of the existing guarantees will be excluded from the debt limits. If pledged reserves of the NBT were to be securitized, these amounts will also be excluded from the debt limits. The performance criterion on new nonconcessional short-term external debt will not apply to loans classified as international reserve liabilities of the NBT (liabilities of the NBT to nonresidents with an original maturity of up to and including one year). Normal import-related financing is excluded from the criterion.

21. Valuation of debt denominated in currencies other than the U.S. dollar. Debts falling within the external debt limits that are denominated in currencies other than the U.S. dollar shall be valued in U.S. dollars at the exchange rate prevailing at the time the contracting or guaranteeing takes place or at the exchange rate stipulated in the contract.

22. Guarantee of a debt. For the purposes of the program, the guarantee of a debt arises from any explicit legal obligation of the general government or the NBT or any other agency acting on behalf of the general government to service such a debt in the event of nonpayment by the debtor (involving payments in cash or in kind), or indirectly through any other obligation of the general government or the NBT or any other agency acting on behalf of the general government to finance a shortfall incurred by the debtors.

\section{Quantitative Performance Criterion 7: Ceiling on disbursements of concessional external financing.}

23. Definition: Disbursements of concessional external financing are defined as disbursements of debt with a grant element equivalent of 35 percent or more.

\section{Quantitative Performance Criterion 8: New external payments arrears (continuous quantitative performance criterion).}

24. Definition. External payments arrears are defined as overdue payments (principal or interest) on external debt contracted, guaranteed, or converted into interstate debt by the general government of Tajikistan or the NBT 30 days beyond the due date and/or applicable the grace period. This definition excludes arrears on debt subject to rescheduling.

\section{Indicative Target 1: Floor on tax collections.}

25. Definition. Tax collections are defined to include all taxes (and custom revenues) collected under the general government budget. Regarding internal taxation, the definition excludes any proceeds from loans, or other banking system credits, the issuance of securities, or from the sale of state assets. Custom revenues are defined to include customs duties and other taxes (including VAT) on international trade and transactions. 


\section{Indicative Target 2: Floor on social- and poverty-related expenditure.}

26. Definition. Social- and poverty-related expenditure is defined as the sum of current and capital expenditures in the education, health, and social protection sectors as shown in the functional classification of the budget.

Indicative Target 3: Ceiling on gross equity sales and contributions for Roghun.

27. Definitions. "Gross equity sales" are defined as all sales of equity in the Roghun OJSC. "Contributions" are defined as all other transfers to Roghun OJSC, the government, or any other public entity for the construction of Roghun, with the exception of direct budget transfers. For purposes of the quarterly indicative target, gross equity sales and contributions will be measured as the difference between the end-of-period balance for the period under evaluation and the preceding end-of-the year balance in all accounts of Roghun OJSC with commercial banks and the NBT, and balances held by the government with commercial banks or the NBT on account of Roghun OJSC, plus the cumulative withdrawals from these accounts for expenditure purposes.

\section{Indicative Target 4: Ceiling on the stock of NBT liquidity loans.}

28. Definition. NBT liquidity loans are defined as short-term liquidity loans by the NBT to domestic commercial banks, credit unions, credit associations, and microfinance organizations with a maturity of up to three months. For the purpose of the quarterly indicative target, the stock of liquidity loans will be calculated as the average of the endmonth stock for the three months during the period under evaluation.

\section{Reporting ReQuirements Under The Program}

29. For program monitoring, the following data should be reported to the Middle East and Central Asia Department of the International Monetary Fund via the IMF Resident Representative's office in Dushanbe. 
Table 1. Data reporting frequency for program monitoring

\begin{tabular}{|c|c|c|}
\hline Data & Frequency & Lag \\
\hline 1. NBT analytical balance sheet & Weekly & $\begin{array}{l}3 \text { working } \\
\text { days }\end{array}$ \\
\hline 2. NBT balance sheet & Weekly & $\begin{array}{c}3 \text { working } \\
\text { days }\end{array}$ \\
\hline 3. Commercial banks' and Kredit Invest balance sheets & Monthly & 4 weeks \\
\hline 4. Auction results for NBT certificates and treasury bills & Weekly & 1 week \\
\hline $\begin{array}{l}\text { 5. Fiscal revenues, expenditures and financing of budget execution, and } \\
\text { extrabudgetary funds }\end{array}$ & Monthly & 4 weeks \\
\hline $\begin{array}{l}\text { 6. Reports and statements from the Agency on Social Protection and } \\
\text { Pensions }\end{array}$ & Quarterly & 6 weeks \\
\hline 7. Arrears of budget entities and state-owned enterprises & Quarterly & 4 weeks \\
\hline 8. Wage and pension arrears by all levels of governments & Monthly & 4 weeks \\
\hline $\begin{array}{l}\text { 9. Stocks, disbursements, guarantees, new contracts of external debt } \\
\text { including terms and disbursement profile, including nonguaranteed } \\
\text { external debt of state-owned enterprises }\end{array}$ & Quarterly & 4 weeks \\
\hline $\begin{array}{l}\text { 10. External arrears arising in respect of obligations incurred directly, } \\
\text { guaranteed, or converted into interstate debt by the general government } \\
\text { of Tajikistan or the NBT, including penalties or interest charges }\end{array}$ & Monthly & 4 weeks \\
\hline $\begin{array}{l}\text { 11. Liquidity loans and loans stemming from fulfillment of the } \\
\text { lender-of-last-resort function extended by the NBT to the economic } \\
\text { agents in Tajikistan (financial sector, nonfinancial sector, enterprises, } \\
\text { individuals, and any other) specifying date of issue, amount of original } \\
\text { loan, interest, term, schedule of repayment, currency, and any grace } \\
\text { period }\end{array}$ & Weekly & 1 week \\
\hline $\begin{array}{l}\text { 12. Net and gross international reserves, including Ministry of Finance } \\
\text { gold holdings, daily sales and purchases of foreign currency, and daily } \\
\text { sales and purchases of foreign currency executed with an intention of } \\
\text { influencing the exchange rate of somoni }\end{array}$ & Daily & $\begin{array}{l}1 \text { working } \\
\text { day }\end{array}$ \\
\hline $\begin{array}{l}\text { 13. Foreign exchange spending of Roghun OJSC, total expenditures of } \\
\text { Roghun OJSC, government transfers to Roghun OJSC, equity } \\
\text { subscriptions by the public to Roghun OJSC, any other receipt of Roghun } \\
\text { OJSC. Balances in all accounts of Roghun OJSC with commercial banks } \\
\text { and the NBT and balances held by the government with commercial } \\
\text { banks or the NBT on account of Roghun OJSC. Cumulative number of } \\
\text { shares sold by denomination. }\end{array}$ & Monthly & 4 weeks \\
\hline
\end{tabular}




\title{
INTERNATIONAL MONETARY FUND
}

\section{REPUBLIC OF TAJIKISTAN}

Staff Report for the 2011 Article IV Consultation, Fourth Review Under the ThreeYear Arrangement Under the Extended Credit Facility, Request for Waiver of Nonobservance for Performance Criteria and Modification of Performance Criterion, and Request for Waivers of Nonobservance of Performance Criteria Resulting in Noncomplying Disbursements

\author{
Informational Annex \\ Prepared by the Middle East and Central Asia Department \\ in Consultation with Other Departments \\ Approved by David Owen and Dhaneshwar Ghura
}

April 26, 2011

Contents

I. Relations with the Fund

II. The JMAP Bank-Fund Matrix

III. Statistical Issues .72 


\section{RELATIONS WITH THE FUND}

(As of February 28, 2011)

I. Membership Status: Joined April 27, 1993; Article VIII

II. General Resources Account:

$\begin{array}{lrr} & \text { SDR million } & \text { \% Quota } \\ \text { Quota } & 87.00 & 100.00 \\ \text { Fund holdings of currency } & 87.00 & 100.00 \\ \text { Reserve position in Fund } & 0.00 & 0.00\end{array}$

\section{SDR Department}

Net cumulative allocation

$\underline{\text { SDR million }}$

\% Allocation

Holdings

82.08

100

69.81

85.04

IV. Outstanding Purchases and Loans

ECF Arrangements

$\underline{\text { SDR million }}$

\% Quota

65.27

75.02

\section{Latest Financial Arrangements}

\begin{tabular}{llcrl} 
Type & $\begin{array}{c}\text { Approval } \\
\text { Date }\end{array}$ & $\begin{array}{c}\text { Expiration } \\
\text { Date }\end{array}$ & $\begin{array}{c}\text { Amount Approved } \\
\text { (SDR million) }\end{array}$ & $\begin{array}{c}\text { Amount Drawn } \\
\text { (SDR million) }\end{array}$ \\
\hline ECF $^{1}$ & Apr 21, 2009 & Apr 20, 2012 & 104.40 & 65.27 \\
ECF & Dec 11, 2002 & Feb 10, 2006 & 65.00 & 65.00 \\
ECF & Jun 24, 1998 & Dec 24, 2001 & 100.30 & 78.28
\end{tabular}

VI. Projected Payments to Fund ${ }^{2}$

\begin{tabular}{lrrrrr}
\hline & \multicolumn{5}{c}{ Forthcoming } \\
\cline { 2 - 6 } & 2011 & 2012 & 2013 & 2014 & 2015 \\
\hline Principal & & & 2.61 & 7.83 \\
Charges/Interest & 0.04 & 0.22 & 0.22 & 0.22 & 0.2 \\
& & & & \\
\hline${ }^{1}$ Formerly PRGF. \\
\end{tabular}



Total
0.04
0.22
0.22
2.83
8.04

VII. Implementation of HIPC Initiative:

Not Applicable

\section{Implementation of Multilateral Debt Relief Initiative (MDRI):}

I. MDRI-eligible debt (SDR Million) ${ }^{3}$

Financed by: MDRI Trust

Remaining HIPC resources

II. Debt Relief by Facility (SDR Million)
69.31

69.31

$--$

\begin{tabular}{llll}
\multicolumn{4}{c}{ Eligible Debt } \\
\hline Delivery Date & $\underline{\text { GRA }}$ & $\underline{\text { PRGT }}$ & $\underline{\text { Total }}$ \\
January 2006 & N/A & 69.31 & 69.31
\end{tabular}

\section{Safeguards Assessment}

An update safeguards assessment of the National Bank of Tajikistan (NBT) — conducted in December 2009 — noted that initial steps have been taken to address the risks identified by the special audit on cotton sector financing. However, considerable safeguards risks at the NBT remain. Both the accounting and the organizational structures are still fragmented, with no oversight over external and internal audits. Internal audit is weak and needs to increase coverage of core functions.

To address these issues, the NBT has implemented a number of initial steps: audited financial statements for end-April 2009 and end-December 2009 were published on the NBT website; an external auditor was reappointed for a multi-year term starting from FY2010; NIR reviews at test dates are being conducted every six months; and the internal audit of core functions was recently outsourced.

\section{Exchange Rate Arrangements}

Since June 2009, the exchange rate regime is classified as stabilized. The official exchange rate is based on all interbank transactions in foreign exchange. It is calculated and announced daily.

\footnotetext{
${ }^{3}$ The MDRI provides 100 percent debt relief to eligible member countries that qualified for the assistance. Grant assistance from the MDRI Trust and HIPC resources provide debt relief to cover the full stock of debt owed to the Fund as of end-2004 that remains outstanding at the time the member qualifies for such debt relief.
} 
With effect from December 9, 2004, the Republic of Tajikistan accepted the obligations of Article VIII, Sections 2, 3, and 4 of the Articles of Agreement. The Republic of Tajikistan maintains an exchange system that is free of restrictions on the making of payments and transfers for current international transactions, except for exchange restrictions maintained for security reasons that have been notified to the Fund pursuant to Executive Board decision No. $144-(52 / 51)$.

\section{FSAP Participation}

Tajikistan participated in the Financial Sector Assessment Program during 2007-08, and the FSSA report has been published at http://www.imf.org/external/country/TJK/index.htm.

\section{Article IV Consultation}

The 2009 Article IV consultation was completed on Apr 21, 2009.

\section{Resident Representative}

Mr. Aisen, Resident Representative of the Fund, started his assignment in Dushanbe in July 2010.

\section{Technical Assistance}

The following list summarizes the technical assistance provided by the Fund to Tajikistan since 2004.

\section{Fiscal Affairs:}

July 2004

December 2004

June 2005

August 2005

August 2006

May 2007

February/July 2010

June 2010

November 2010
Revenue Administration Reform

Poverty and Social Impact Analysis

Public Financial Management

Tax Policy and Administration

Fiscal ROSC

Public Financial Management (Budget Classification)

Tax Policy and Administration

Public Financial Management Reforms

Public Financial Management (Regional Advisor)

\section{Monetary and Financial Systems:}


May 2006

October/December 2009 and September 2010

January 2011

Statistics:

April 2004

October 2004

June 2006

March 2011

\section{Legal:}

January 2004

May 2004

2006

October 2010
Strengthening the Monetary Policy Framework and Liquidity Management

NBT Recapitalization Strategy

Improving Accounting Controls at NBT

Data ROSC

General Data Dissemination System (GDDS)

Report on Monetary and Financial Statistics

National accounts and price statistics (Regional Advisor)

BOP

Tax Legislation

Tax Legislation

$\mathrm{AML} / \mathrm{CFT}$

NBT Law 


\section{THE JMAP BANK-FUND MATRIX}

(As of March 31, 2011)

\begin{tabular}{|c|c|c|c|}
\hline Title & $\begin{array}{l}\text { Products and Brief } \\
\text { Description (pillars) }\end{array}$ & $\begin{array}{c}\text { Provisional Timing of } \\
\text { Missions }\end{array}$ & $\begin{array}{c}\text { Expected Date of } \\
\text { Delivery }\end{array}$ \\
\hline \multicolumn{4}{|c|}{ A. Mutual information on relevant work programs } \\
\hline \multirow[t]{6}{*}{$\begin{array}{l}\text { Bank Work Program } \\
\text { in next } 12 \text { months }\end{array}$} & $\begin{array}{l}\text { PDPG 5 } \\
\text { - Protecting delivery of basic } \\
\text { services within a sustainable } \\
\text { fiscal framework } \\
\text { - Improving the environment } \\
\text { for private sector } \\
\text { development and growth } \\
\text { - Strengthening government } \\
\text { effectiveness }\end{array}$ & $\begin{array}{l}\text { Identification/Pre-appraisal } \\
\text { November } 2010 \\
\text { Appraisal April } 2011\end{array}$ & $\begin{array}{l}\text { Board June } 2011 \\
\text { Disbursement: July } \\
2011\end{array}$ \\
\hline & $\begin{array}{l}\text { Private Sector Development } \\
\text { Dialogue }\end{array}$ & $\begin{array}{l}\text { PSD TA support (Doing } \\
\text { Business) ongoing since } 2008 \\
\text { until June } 2011\end{array}$ & \\
\hline & $\begin{array}{l}\text { Rural Investment Climate Study } \\
\text { (with DFID TF) }\end{array}$ & Field work starts April 2011 & \\
\hline & Governance & $\begin{array}{l}\text { Institutional and Governance } \\
\text { Review-development of } \\
\text { analytical work } \\
\text { Supporting demand-side } \\
\text { governance-Governance } \\
\text { Partnership Facility funded } \\
\text { by DFID-Bank executed TF } \\
\text { 2011-13 }\end{array}$ & December 2011 \\
\hline & $\begin{array}{l}\text { Agriculture } \\
\text { Expand farmland restructuring } \\
\text { to enable more rural people to } \\
\text { become independent }\end{array}$ & $\begin{array}{l}\text { Supervision of Land } \\
\text { Registration and Cadastral } \\
\text { System Project } \\
\text { March } 2011 \\
\text { September } 2011\end{array}$ & $\begin{array}{l}\text { Project closing } \\
\text { March } 2012\end{array}$ \\
\hline & $\begin{array}{l}\text { Build productive assets of rural } \\
\text { communities in selected } \\
\text { mountain watersheds }\end{array}$ & $\begin{array}{l}\text { Supervision of Community } \\
\text { Agriculture and Watershed } \\
\text { Management Project } \\
\text { March } 2011 \\
\text { September } 2011\end{array}$ & $\begin{array}{l}\text { Project closing April } \\
2011 \text {, to be extended } \\
\text { to end } 2012\end{array}$ \\
\hline
\end{tabular}




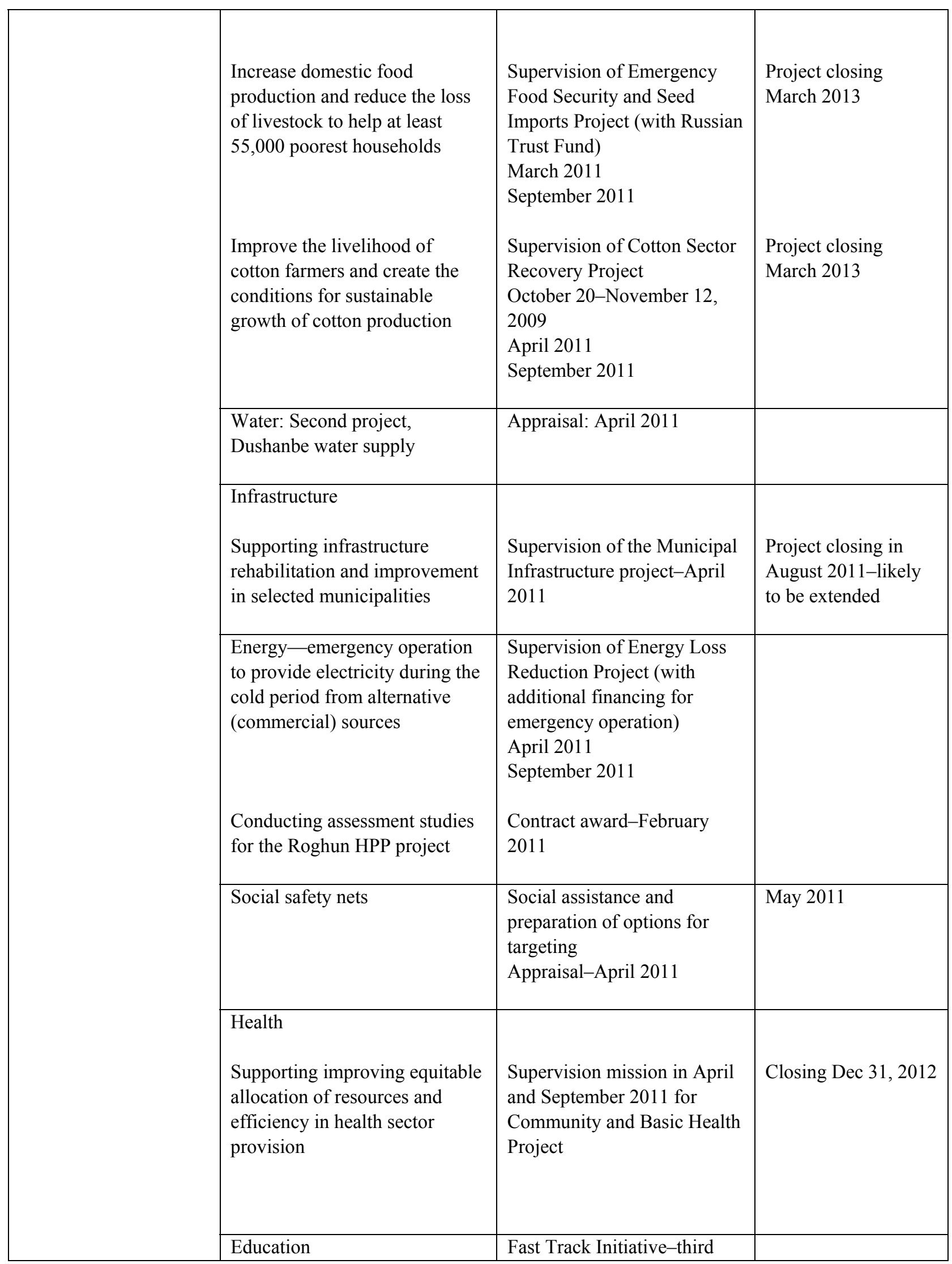




\begin{tabular}{|c|c|c|c|}
\hline & & $\begin{array}{l}\text { grant, starting April } 2010 \\
\text { Supervision-March } 2011 \\
\text { Education Modernization } \\
\text { (incl. Additional Financing) } \\
\text { Supervision-October, March } \\
\text { and September } 2011\end{array}$ & \\
\hline & Financial Sector & $\begin{array}{l}\text { FIRST TA consultant mission } \\
\text { on bank insolvency law and } \\
\text { secured transactions reform } \\
\text { (law and registry) } \\
\text { August } 2010 \\
\text { WB missions to initiate } \\
\text { FIRST TAs: March } 2011 \\
\text { WB missions to monitor } \\
\text { FIRST TAs and } \\
\text { implementation of } \\
\text { government-approved FSD } \\
\text { action plan: May } 2011\end{array}$ & \\
\hline & Migration & $\begin{array}{l}\text { IDF grant to support } \\
\text { improvement of M\&E works } \\
\text { in the migration service under } \\
\text { the government of Tajikistan } \\
\text { May } 2011\end{array}$ & \\
\hline & Mining & $\begin{array}{l}\text { IDF grant to support mining } \\
\text { sector study and reforms and } \\
\text { possibility of Tajikistan } \\
\text { joining EITI } \\
\text { September } 2011\end{array}$ & \\
\hline $\begin{array}{l}\text { Fund work program } \\
\text { in next } 12 \text { months }\end{array}$ & $\begin{array}{l}\text { - Fifth ECF review } \\
\text { - Tax Policy TA } \\
\text { - Sixth ECF review }\end{array}$ & $\begin{array}{l}\text { - September } 2011 \\
\text { - April } 2011 \\
\text { - February } 2012\end{array}$ & $\begin{array}{l}\text { - November } 2011 \\
\text { - May-June } 2011 \\
\text { - April } 2012\end{array}$ \\
\hline \multicolumn{4}{|c|}{ B. Requests for work program inputs } \\
\hline Fund request to Bank & $\begin{array}{l}\text { - Follow-up on Barki Tajik } \\
\text { audit } \\
\text { - Electricity tariff increases } \\
\text { - Roghun feasibility study } \\
\text { - Cotton/agriculture sector } \\
\text { reforms } \\
\text { - Any STATCAP work on NA }\end{array}$ & & \\
\hline
\end{tabular}




\begin{tabular}{|c|c|c|c|}
\hline & $\begin{array}{l}\text { and inflation statistics } \\
\text { - PFM work } \\
\text { - Social spending } \\
\text { - Financial sector work }\end{array}$ & & \\
\hline Bank request to Fund & $\begin{array}{l}\text {-Provide BOP/fiscal data for } \\
\text { updating macro database } \\
\text {-Assessment Letter for PDPG } 5\end{array}$ & & May 2011 (tentative) \\
\hline \multicolumn{4}{|c|}{ C. Agreement on joint products and missions (as needed) } \\
\hline $\begin{array}{l}\text { Joint products in next } \\
12 \text { months }\end{array}$ & $\begin{array}{l}\text { Low Income Debt } \\
\text { Sustainability Analysis }\end{array}$ & February 2012 & April 2012 \\
\hline
\end{tabular}




\section{STATISTICAL ISSUES}

(As of March 31, 2011)

\section{Assessment of Data Adequacy for Surveillance}

30. General: Data provision has some shortcomings in the areas of national accounts, price statistics, and monetary statistics, but is broadly adequate for surveillance.

31. National accounts and price statistics: There are significant deficiencies in the statistical techniques for national accounts and price statistics, most notably in procedures to estimate the informal economy, and the techniques for imputation, replacement, quality adjustment, and introduction of new products in the price indices. Technical assistance from the World Bank and the Fund has recently focused on the quarterly calculations of GDP by expenditure and sectors, a framework for reconciling the two approaches, and the improvement of accuracy of the annual estimates. As regards to price statistics, the most important general issue is the further implementation of the system of prices and volumes, instead of presently used comparable volumes.

32. Government finance statistics: Government finance statistics (GFS) are based on cash transactions as recommended in the 1986 Manual on Government Finance Statistics. There are no plans to migrate the basis of compilation to the 2001 Government Finance Statistics Manual. In 2010, the authorities introduced an administrative classification of the budget. However, there are occasional budget classification issues within the economic classification of expenditures and the classification of above- and below-the-line transactions, which are being resolved with the help of a regional advisor.

33. Monetary and financial statistics: The safeguard assessment in 2010 concluded that the accounting function at the NBT is still fragmented and needs to be strengthened. These risks are mitigated by the statutory audits of the financial statements and the ongoing semiannual NIR reviews by external audit firms. The authorities have yet not adopted the latest methodology for the compilation of monetary statistics and reporting of monetary data through the standardized report forms introduced to all IMF member countries in 2004. Thus, the monetary data published in International Financial Statistics are outdated with respect to the methodology and timeliness as well.

34. Balance of payments: There is a need for consistency in applying the residency concept in the balance of payments and the national accounts, and the scope of the foreign trade data needs to be improved to cover the shuttle trade.

\section{Data Standards and Quality}

35. Tajikistan began participating in the General Data Dissemination System (GDDS) on November 17, 2004. Metadata is updated regularly. The authorities have indicated their interest in graduating from the GDDS to the Fund's Special Data Dissemination Standard 
(SDDS). They have appointed a national SDDS coordinator and requested technical assistance for this purpose.

36. Data ROSC was published on March 30, 2005.

\section{Reporting to STA}

Country page in the International Financial Statistics (IFS) has been published since February 2003. 
Tajikistan: Table of Common Indicators Required for Surveillance (As of March 31, 2011)

\begin{tabular}{|c|c|c|c|c|c|c|c|}
\hline & \multirow[b]{2}{*}{$\begin{array}{l}\text { Date of latest } \\
\text { observation }\end{array}$} & \multirow[b]{2}{*}{$\begin{array}{l}\text { Date } \\
\text { received }\end{array}$} & \multirow[b]{2}{*}{$\begin{array}{c}\text { Frequency } \\
\text { of } \\
\text { data }^{6}\end{array}$} & \multirow[b]{2}{*}{$\begin{array}{l}\text { Frequency } \\
\quad \text { of } \\
\text { reporting }^{6}\end{array}$} & \multirow[b]{2}{*}{$\begin{array}{l}\text { Frequency } \\
\text { of } \\
\text { publication }\end{array}$} & \multicolumn{2}{|c|}{ Memo Items: } \\
\hline & & & & & & $\begin{array}{l}\text { Data Quality - } \\
\text { Methodological } \\
\text { soundness }^{7}\end{array}$ & $\begin{array}{l}\text { Data Quality - } \\
\text { Accuracy and } \\
\text { reliability }^{8}\end{array}$ \\
\hline Exchange Rates & $03 / 25 / 11$ & $03 / 29 / 11$ & $\mathrm{D}$ & W & W & & \\
\hline $\begin{array}{l}\text { International Reserve Assets and } \\
\text { Reserve Liabilities of the Monetary } \\
\text { Authorities }{ }^{1}\end{array}$ & $03 / 25 / 11$ & $03 / 29 / 11$ & $\mathrm{D}$ & W & W & & \\
\hline Reserve/Base Money & $03 / 18 / 11$ & $03 / 29 / 11$ & W & M & $\mathrm{W}$ & $\mathrm{O}, \mathrm{O}, \mathrm{LO} \mathrm{O}$ & $\mathrm{LO}, \mathrm{O}, \mathrm{O}, \mathrm{O}, \mathrm{NO}$ \\
\hline Broad Money & $01 / 31 / 11$ & 03/16/11 & M & M & M & & \\
\hline Central Bank Balance Sheet & 03/18/11 & $03 / 29 / 11$ & W & M & W & & \\
\hline Consumer Price Index & $\mathrm{Feb} / 11$ & $03 / 28 / 11$ & M & M & M & LO, LO, LNO, O & $\begin{array}{l}\mathrm{LO}, \mathrm{LO}, \mathrm{LO}, \mathrm{O}, \\
\mathrm{O}\end{array}$ \\
\hline $\begin{array}{l}\text { Revenue, Expenditure, Balance and } \\
\text { Composition of Financing }{ }^{3-} \text { General } \\
\text { Government }^{4}\end{array}$ & $\operatorname{Jan} / 11$ & $03 / 30 / 11$ & M & M & M & LO, LO, O, O & $\mathrm{O}, \mathrm{O}, \mathrm{O}, \mathrm{LO}, \mathrm{LO}$ \\
\hline $\begin{array}{l}\text { Revenue, Expenditure, Balance and } \\
\text { Composition of Financing }{ }^{3} \text { - Central } \\
\text { Government }\end{array}$ & $\mathrm{Jan} / 11$ & $03 / 30 / 11$ & M & M & M & & \\
\hline $\begin{array}{l}\text { Stocks of Central Government and } \\
\text { Central Government-Guaranteed Debt }\end{array}$ & $\mathrm{Q} 4 / 10$ & $01 / 25 / 11$ & Q & Q & V & & \\
\hline Gross External Debt ${ }^{5}$ & $\mathrm{Q} 4 / 10$ & $01 / 25 / 11$ & Q & Q & V & & \\
\hline
\end{tabular}

${ }^{1}$ Includes reserve assets pledged or otherwise encumbered, as well as net derivative positions.

${ }^{2}$ Both market-based and officially determined, including discount rates, money market rates, and rates on treasury bills, notes and bonds.

${ }^{3}$ Foreign, domestic bank, and domestic nonbank financing.

${ }^{4}$ The general government comprises central government (budgetary, extra budgetary, and social protection funds) and state and local governments.

${ }^{5}$ Including currency and maturity composition.

${ }^{6}$ Daily (D), Weekly (W), Monthly (M), Quarterly (Q), Annually (A); NA: Not Available.

${ }^{7}$ Reflects the assessment provided in the data ROSC published in April 2005 and based on the findings of the staff mission during April 2004 for the dataset corresponding to the variable in each row. The assessment indicates whether international standards concerning concepts and definitions, scope, classification/sectorization, and basis for recording are fully observed (O), largely observed (LO), largely not observed (LNO), or not observed (NO).

${ }^{8}$ Same as footnote 7, except referring to international standards concerning source data, statistical techniques, assessment and validation of source data, assessment and validation of intermediate data and statistical outputs, and revision studies. 


\title{
INTERNATIONAL MONETARY FUND
}

REPUBLIC OF TAJIKISTAN

\section{Debt Sustainability Analysis Under the Debt Sustainability Framework for Low Income Countries}

\author{
Prepared by the Staffs of the International Monetary Fund and the World Bank \\ Approved by David Owen and Daneshwar Ghura (IMF) and \\ Jeffrey D. Lewis and Yvonne Tsikata (World Bank)
}

April 26, 2011

Based on the external low income country (LIC) debt sustainability analysis (DSA), Tajikistan's risk of debt distress remains high. ${ }^{1}$ Under the baseline scenario, external debt burden indicators in present value terms remain below their respective indicative thresholds, with the exception of the debt-to-exports ratio. Stress tests within the public DSA demonstrate the sensitivity of the fiscal position with respect to a slightly lower long run growth rate and the necessity of the assumed fiscal consolidation. The DSA results thus underscore the need for: i) the planned fiscal consolidation; ii) caution in contracting new debt; and iii) careful cost-benefit assessment of large-scale investment projects, to make sure that external resources are used productively. Furthermore, a one-off increase in the government's debt obligations, e.g. related to existing contingent liabilities, would push the debt-to-GDP ratio higher, but would not put the country on an unsustainable debt path in the long run. Sound macroeconomic policies and acceleration of structural reforms would also be needed to strengthen Tajikistan's growth potential and safeguard external stability.

\section{BACKGROUND}

\section{While declining significantly over the last decade, Tajikistan's debt burden} remains high. Tajikistan's external debt ${ }^{2}$ to GDP ratio decreased from slightly over 100 percent in 2000 to about $34 \frac{1}{2}$ percent in 2010. A debt-for-equity swap with Russia in 2004 reduced considerably the debt burden and tilted the composition of debt toward multilaterals. Against the backdrop of a sharp increase in loans from China since 2007, the share of bilateral creditors picked up rapidly. As of end-2010, Tajikistan's external debt is

\footnotetext{
${ }^{1}$ The DSA has been produced jointly by World Bank and IMF staff, in consultation with Asian Development Bank staff. It updates the last DSA of May 2010 presented in the IMF Staff Report for the First and Second Review under the Extended Credit Facility (EBS/10/95, 05/24/2010). The fiscal year for Tajikistan is January 1-December 31.

${ }^{2}$ Tajikistan's public and publicly guaranteed external debt covers the general government and both guaranteed and non-guaranteed debt of SOEs (state-owned enterprises).
} 
largely concessional and held in broadly equal parts between multilateral and bilateral creditors, with the share of China quite prominent at about 38 percent. The share of commercial creditors is small. ${ }^{3}$

\section{Domestic debt has constituted a very small part of overall public debt owing to} low primary fiscal deficits (excluding the externally financed public investment program) and a shallow government securities market. Domestic debt represented about 2 percent of GDP ( 6 percent of total public debt) at end-2010, consisting mostly of nontradable government securities held by the National Bank of Tajikistan (NBT). Since 2009, the government has undertaken regular issuance of Treasury-bills (T-bills), but only in small amounts, with short maturity, and at rates below the current NBT refinancing rate. ${ }^{4}$ Moreover, eight-year government bonds were issued to commercial banks in 2010 as part of the cotton debt resolution with rollover provisions and an interest rate of only 2 percent.

\section{The present value (PV) of public and publicly guaranteed (PPG) external debt at} end-2010 was higher than projected in the last DSA, mainly on account of higher external borrowing. PPG external debt came to about $34 \frac{1}{2}$ percent of GDP at end-2010 - roughly $2 \frac{1}{2}$ percent of GDP higher than projected in the last DSA update.

\section{The current DSA concludes that Tajikistan's risk of debt distress remains high}

(see Figure 1). ${ }^{5}$ The PV of PPG external debt to exports of goods and services stood at 147 percent at end-2010, significantly above its threshold, and prolonged breaches of the threshold throughout the projection period are anticipated. Other debt burden indicators are projected to remain below their respective thresholds under the baseline scenario. In Tajikistan, remittance inflows have become the most prominent source of foreign exchange earnings through a dramatic structural increase from less than 10 percent of GDP in 2003 to

\footnotetext{
${ }^{3}$ In addition, the authorities accumulated a trivial amount of arrears, which are not taken into account in this DSA as they do not have any macroeconomic impact. External payments arrears were accumulated in 2010 on two loans guaranteed by the government. For the first loan, arrears reached a maximum of Euro 103,032 (US\$148,428) during the course of the year. Original payment arrears were cleared by end-August 2010, and penalty interest was cleared by end-December. For the second loan, arrears of US $\$ 216$ was cleared in January 2011.

${ }^{4}$ In 2010, the total level of issuance was less than 0.3 percent of GDP.

${ }^{5}$ According to the latest three-year average of the World Bank's CPIA rating (2007-09) of 3.2, Tajikistan's policies and institutions are assessed as those corresponding to a "weak performer."Three-year average of CPIA ratings is used according to recently issued joint Bank-Fund Staff Guidance Note on the Application of the joint Bank-Fund Debt Sustainability Framework (October 2008). These guidelines aim at a less volatile assessment of risk than that based on a single latest CPIA rating. The thresholds for the debt burden for weak performers are 100, 30 and 200 for the NPV of debt to exports, GDP and revenue respectively; debt service thresholds are 15 and 25 percent of exports and revenue, respectively. In the scenarios that include remittances, the thresholds have been revised downward by 10 percent so the corresponding threshold for NPV of debt and debt service to exports and remittances is 90 percent and is $13 \frac{1}{2}$ respectively.
} 
almost 40 percent in 2010 (after posting a pre-global crisis peak of 49 percent of GDP in 2008). However, projected prolonged breaches of the original threshold for the NPV of debt-to-exports ratio under the baseline scenario and stress tests preclude the incorporation of remittances in the debt sustainability assessment. ${ }^{6}$ If debt burden indicators incorporating remittances in the denominator are used, Tajikistan's risk of debt distress would likely be reduced to medium (see Figure 2).

\section{UNDERLYING DSA ASSUMPTIONS}

5. The macroeconomic framework over the medium term is broadly comparable to the one presented in the last DSA and is described in more detail in Box 1.

- Tajikistan's underlying growth potential is projected to be about 5 percent, broadly comparable to the last DSA. Real GDP growth in 2010 turned out stronger than projected at $6 \frac{1}{2}$ percent, supported by robust growth in remittances and a pickup in manufacturing and construction.

- On account of anticipated terms of trade shocks in 2011 and 2012, a modest depreciation of the real effective exchange rate is incorporated, which would help bring the current account balance towards its estimated medium-term norm. ${ }^{7}$

- Medium- and long-term projections for growth in nondebt creating flows are comparable to the last DSA (see Table 1a).

- Underlying assumptions for the fiscal projections are that the government budget deficit (excluding Public Investment Program) of about 1 percent of GDP in 2011 will be eliminated in the medium term and beyond. This seems feasible based on current spending plans and revenue projections.

\footnotetext{
${ }^{6}$ Staff Guidance Note on the Application of the Joint Bank-Fund Debt Sustainability Framework for Low Income Countries (Jan 25, 2010 available from http://www.imf.org/external/pp/longres.aspx?id=4419) identifies the maximum permissible length of the breach of the thresholds as 10 years starting from the current period, i.e., half of the projection period.

${ }^{7}$ Based on the Methodology for the Consultative Group on Exchange Rate Issues (CGER) Exchange Rate Assessments (November 8, 2010 available from http://www.imf.org/external/np/pp/eng/2006/110806.pdf).
} 


\section{Box 1. Tajikistan: Macroeconomic Assumptions}

Real GDP growth is projected at 53/4 percent in 2011, and at 5 percent beyond 2011 . These figures are significantly below their ten-year historical average of 8 percent (2001-10). The historical output trajectory was supported by fast growth in the aftermath of the civil war, a sharp structural increase in remittances during 2004-08, and a benign global environment for the most part of the historical base. Expected long-term growth will be driven primarily by exports once investment in the energy sector is completed and structural reforms trigger a more dynamic private sector. The U.S. dollar GDP deflator is projected to increase from 6 percent in 2010 to 12 percent in 2011, but expected to decelerate to about 3 percent through 2031 reflecting progress toward a low-inflation environment while assuming no commodity price shocks beyond the medium term.

Export of goods and services is expected to pick up to an average of 9 percent during 2011-16, despite a projected sharp deceleration in 2012 on account of an anticipated adverse shock to cotton prices. Expansion in nontraditional agriculture sectors and increase in energy exports would support this growth. An average growth rate of about 73/4 percent is projected for 2016-31 as export will be supported by completion of the infrastructure projects in the energy sector and progress with structural reforms, including in the agriculture sector and improvement in the business environment.

The external current account posted a surplus of $2 \frac{1}{4}$ percent of GDP in 2010 . However, the improvement is expected to be temporary with the current account reverting to a deficit of 33/4 percent of GDP in 2011 in light of anticipated adverse terms of trade shocks (higher food and fuel prices), the full year impact of Russian export duties on fuel (imposed in May 2010), and the reversal of the one-off factors that curbed imports in 2010 (intermittent blockade of rail transit during the first half of 2010 and a slowdown in external disbursements for the Public Investment Program). A projected significant drop in cotton prices in 2012 would add to the balance of payments pressures. Reflecting these adverse shocks, a modest depreciation of the real effective exchange rate that would help bring the current account balance close to its medium-term norm is factored in. During 2012-15 external borrowing on concessional terms to finance the construction of Roghun HPP is incorporated. Owing to its high import content, the current account deficit is expected to rise temporarily to a range of 6-7 percent of GDP. Beyond the medium term, the current account balance is expected to improve gradually. Reserve coverage is projected to build up gradually to about $3 \frac{1 / 4}{4}$ months of imports by 2031 .

Fiscal policy is assumed to aim for an overall balance (excluding the externally financed public investment program) over the medium term and beyond, after modest deficits in 2009-11.

External assistance. Official external loan financing on concessional terms is estimated to decline from 43/4 percent of GDP in 2011 to 23/4 percent of GDP through 2031. The grant element of new external debt is assumed to decline slightly to 31 percent from 35 percent over the projection horizon.

Public domestic debt. A modest increase in domestic debt to GDP ratio is assumed from about 2 percent to $5 \frac{1}{2}$ percent by 2017 and gradually declining to 4 percent by 2031 .

Real interest rates. For domestic debt, it is expected that real interest rate becomes slightly positive starting 2016. 


\section{EXTERNAL DSA}

\section{A. Baseline}

6. Under the baseline scenario, only one of Tajikistan's external debt burden indicators, the PV of debt-to-exports ratio, is projected to breach the indicative policy-dependent thresholds significantly and for a protracted period of time (see Figure 1 and Table 1a). The debt-to-exports ratio will peak at 178 percent in 2015, exceeding the threshold of 100 percent significantly. After that, it is projected to decrease gradually throughout 2031. However, during the entire projection period the threshold will be breached by a wide margin.

7. External debt service ratios are expected to stay below their thresholds over the entire period. During the projection period, debt service payments continue to be manageable, albeit spiking during the years when principal payments on loans from China fall due. As a result, from 2016 to 2019, the debt service-to-export trajectory approaches the indicative threshold. It is assumed that all of Tajikistan's external public and publicly guaranteed debt is contracted on concessional terms.

\section{B. Alternative Scenarios and Stress Tests}

8. Under the historical scenario, the debt burden indicators are significantly lower than under the baseline scenario. The historical scenario is based on averages from 2001 to $2010,{ }^{8}$ during which the current account deficit was relatively low_-at below 3 percent of GDP, and growth was much stronger. Therefore, under this scenario, all debt burden ratios - excluding the PV of debt-to-exports ratio - remain well below the baseline trajectory and follow a downward trend throughout the projection period.

9. A high-investment low-growth scenario underscores the risk to debt sustainability if growth dividends are less than projected (see Table 1b). The scenario demonstrates that, starting in 2012, when growth is reduced by half due to lower-than-expected productivity of investments, all ratios deteriorate notably, with the ratio of the PV of debt-to-GDP approaching its sustainability threshold by the end of projection period. The ratio of the PV of debt-to-exports deteriorates even further. Nevertheless, the growth projections under the baseline are already cautious and no significant growth impact from the completion of Roghun HPP and other energy projects are incorporated. Consequently, a high-investment low-growth scenario may prove pessimistic.

\footnotetext{
${ }^{8}$ For exports and noninterest current account averages for only 2006-10 were used due to a break in the export series reflecting a change in the treatment of exports of aluminum in the current account. For all others, the usual ten-year historical average was applied.
} 
10. A scenario assuming contracting external debt on less favorable terms would lead to a significant deterioration of Tajikistan's external debt indicators compared to the baseline scenario. If all new borrowing were to be contracted on less favorable terms during the projection period, Tajikistan's PV of debt-to-export ratio would rise substantially. Specifically, with the increase in the average interest rate on new disbursements by 2 percentage points, the PV of debt-to-GDP ratio would rise continuously and breach the threshold starting in 2030, and the PV of debt-to-exports ratio would increase further from levels projected under the baseline and stay above the threshold.

\section{Bound tests show that adverse macroeconomic shocks would also have a} profound negative impact on Tajikistan's external position. In the event of a shock to nondebt creating inflows, all ratios, except debt service-to-revenues, exceed the indicative policy-dependent thresholds by a significant margin and almost all of them remain above the thresholds throughout the projection period.

\section{Public DSA}

12. The baseline trajectory in the public sector DSA is very similar to the trajectory in of the external DSA, given that public sector domestic debt is small. The most extreme stress test is embodied in a lower long run growth compared to the baseline. In other words, a growth rate 0.5 percentage points smaller compared to the one assumed in the baseline would result in ever-increasing trajectories of all solvency and liquidity debt burden measures in the public template. This stress reflects the sensitivity of fiscal sustainability to the underlying growth assumption. Another important stress test in the public sector DSA includes the impact of the government facing a contingent liability notionally equal to 10 percent of GDP. ${ }^{9}$ In this scenario, the PV of debt-to-GDP ratio peaks at 40 in 2015, indicating considerable risks to debt sustainability from contingent fiscal liabilities. Under low growth and/or fixed primary balance scenarios public debt is unsustainable (see Figure 3). This highlights the importance of relying fully on concessional financing and risks associated with diverging from the fiscal consolidation assumed in the baseline scenario.

\section{DEbT Distress Classification and Conclusions}

13. The current DSA concludes that Tajikistan's risk of debt distress remains high. The PV of PPG external debt to exports of goods and services breaches the indicative threshold significantly throughout the projection period. Other debt burden indicators are projected to remain below their respective thresholds under the baseline scenario.

\footnotetext{
${ }^{9}$ Possible contingent fiscal liabilities stem from nonperforming loans in the financial system and arrears (tax and inter-enterprise) in the state enterprises. The figure of 10 percent of GDP is notional, but likely represents an outer bound for potential fiscal costs.
} 
14. The results of the alternative scenarios and stress tests indicate that the debt sustainability situation could further deteriorate. A modestly lower long run growth rate, borrowing on less favorable terms of financing or absence of a fiscal consolidation could result in an unsustainable debt burden trajectory. The DSA results thus underscore the need for fiscal consolidation and extreme caution in contracting new debt and to carefully vet large-scale investment projects, to make sure that external resources are used productively. Sound macroeconomic policies and acceleration of structural reforms would also be essential for maintaining debt sustainability by strengthening Tajikistan's growth potential and safeguarding external stability. Going forward, continued emphasis should also be placed on strengthening debt management capacity by closely monitoring the debts of the state-owned enterprises (SOEs), assessing potential contingent liabilities arising from the financial sector and quasi-fiscal activities of SOEs. The mission highly recommended the authorities to undertake the Debt Management and Performance Assessment (DEMPA) to identify and address weaknesses in various aspects of Tajikistan's debt management institutions and practices.

15. The authorities concurred with the conclusions of the DSA exercise. The External Debt Unit at the Ministry of Finance has received technical assistance to improve the in-house capacity for debt sustainability assessment. The authorities' results were in agreement with the staff findings. In response to the authorities' request, a World Bank DEMPA mission will take place during April 14-24, 2011. Staff welcomed the authorities' voluntary and swift action in this area that will help facilitate assessment of the strengths and weaknesses in debt management and design of actionable reform plans to improve debt management capacity. 
Figure 1. Tajikistan: Indicators of Public and Publicly Guaranteed

External Debt under Alternatives Scenarios, 2011 - 2031 1/
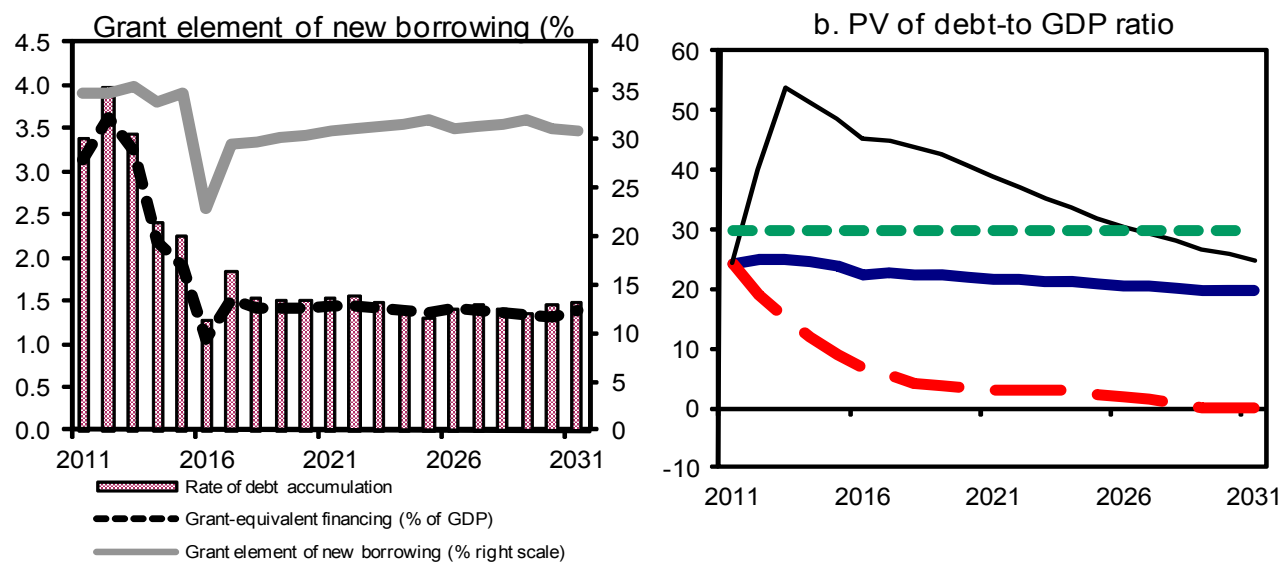

c. PV of debt-to-exports ratio

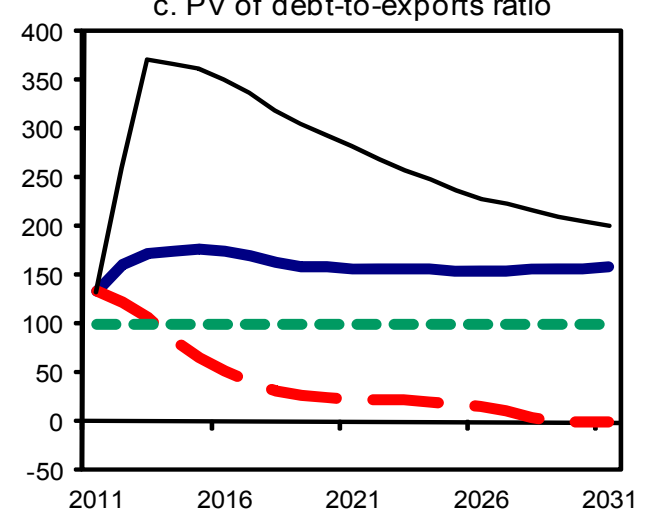

d. PV of debt-to-revenue ratio

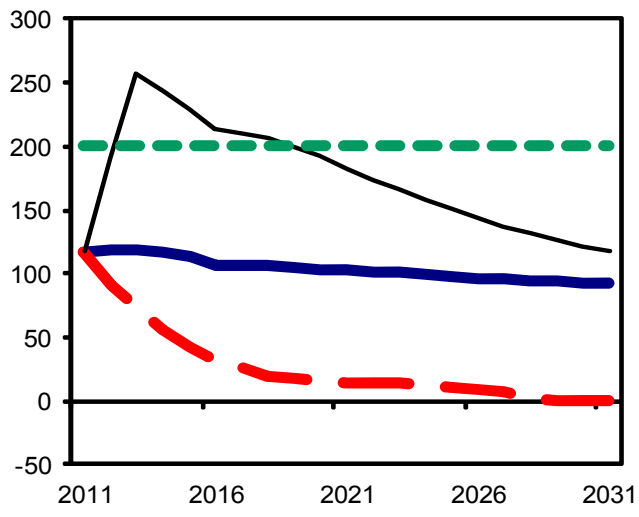

e. Debt service-to-exports ratio
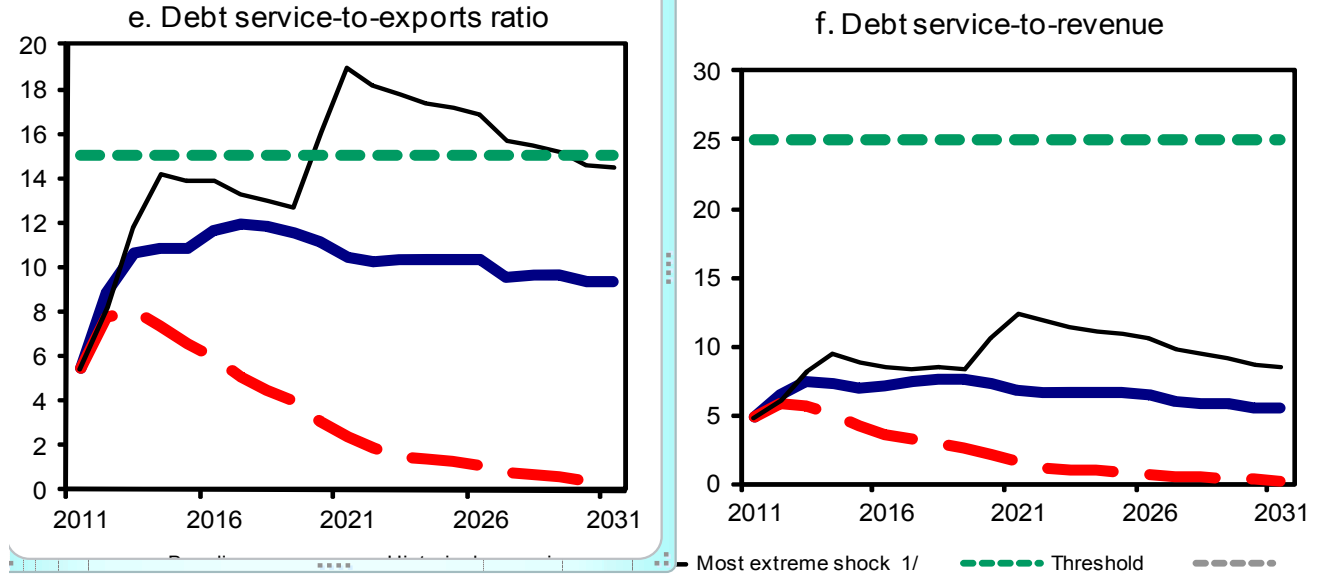

Sources: Country authorities; and IMF staff estimates and projections.

$1 /$ The most extreme stress test is the test that yields the highest ratio in 2021. In all figures it corresponds to a nondebt creating flows shock. 
Figure 2. Tajikistan: Indicators of Public and Publicly Guaranteed External Debt under Alternatives Scenarios Incorporating Remittances, 2011 - 2031 1/
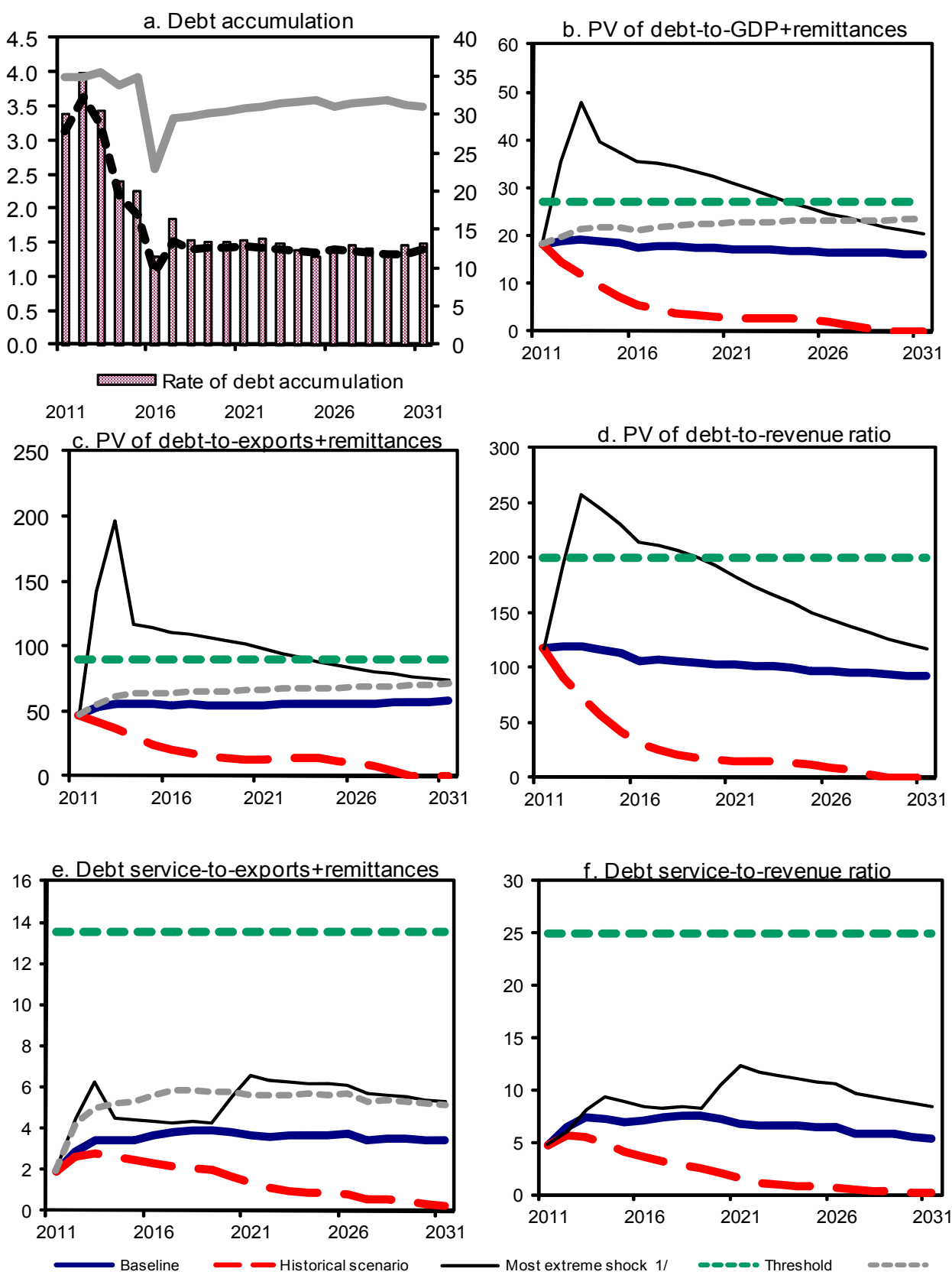

Sources: Country authorities; and IMF staff estimates and projections.

$1 /$ The most extreme stress test is the test that yields the highest ratio in 2021. In all figures it corresponds to a nondebt creating flows shock. 
Figure 3. Tajikistan: Indicators of Public Debt Under Alternative Scenarios, 2011 - 2031 //
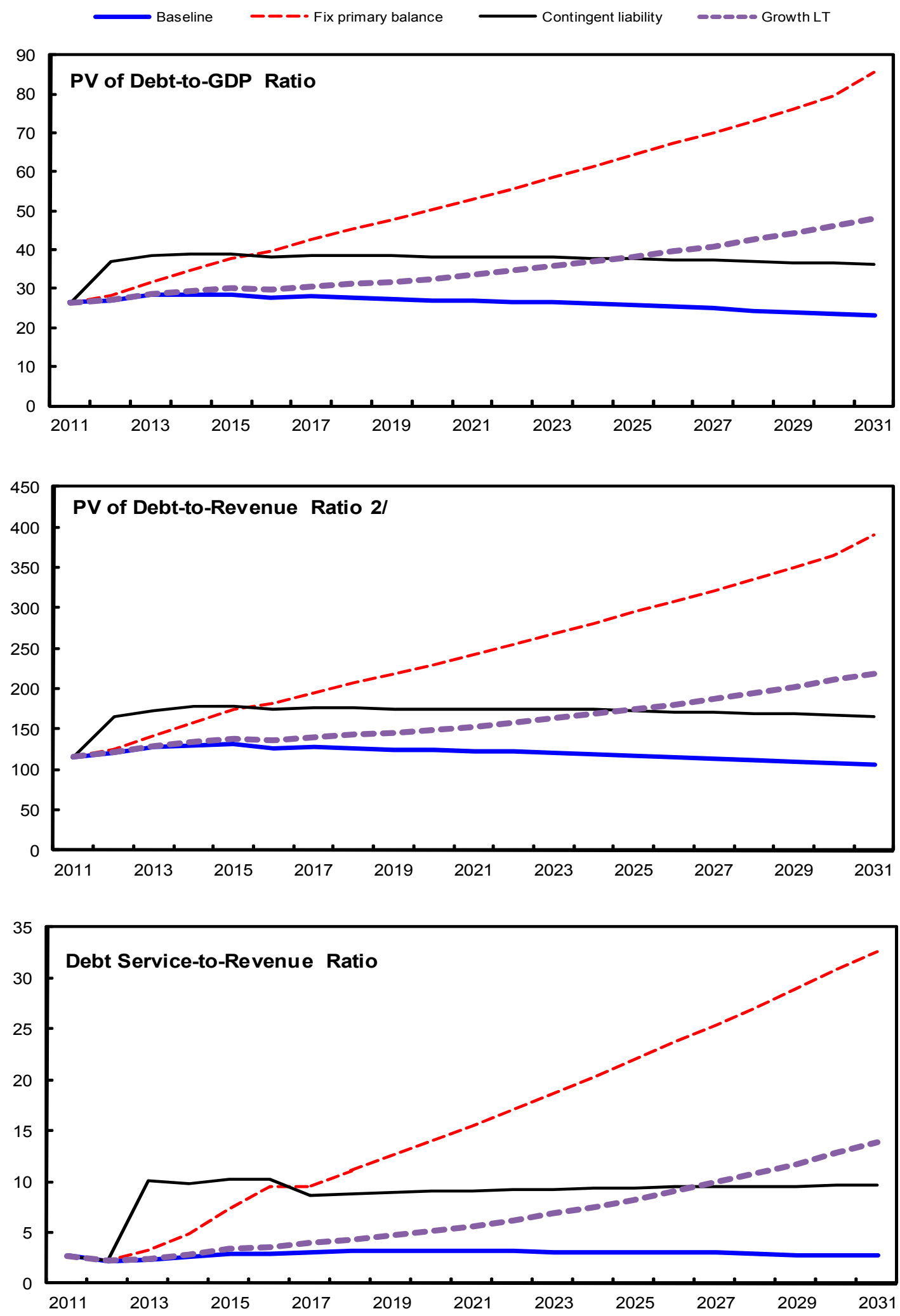

Sources: Country authorities; and IMF staff estimates and projections.

1/ The most extreme stress test is the test that yields the highest ratio in 2021.

2/ Revenues are defined inclusive of grants. 
Table la.: External Debt Sustainability Framework, Baseline Scenario, 2008-2030 1

(In percent of GDP, unless otherwise indicated)

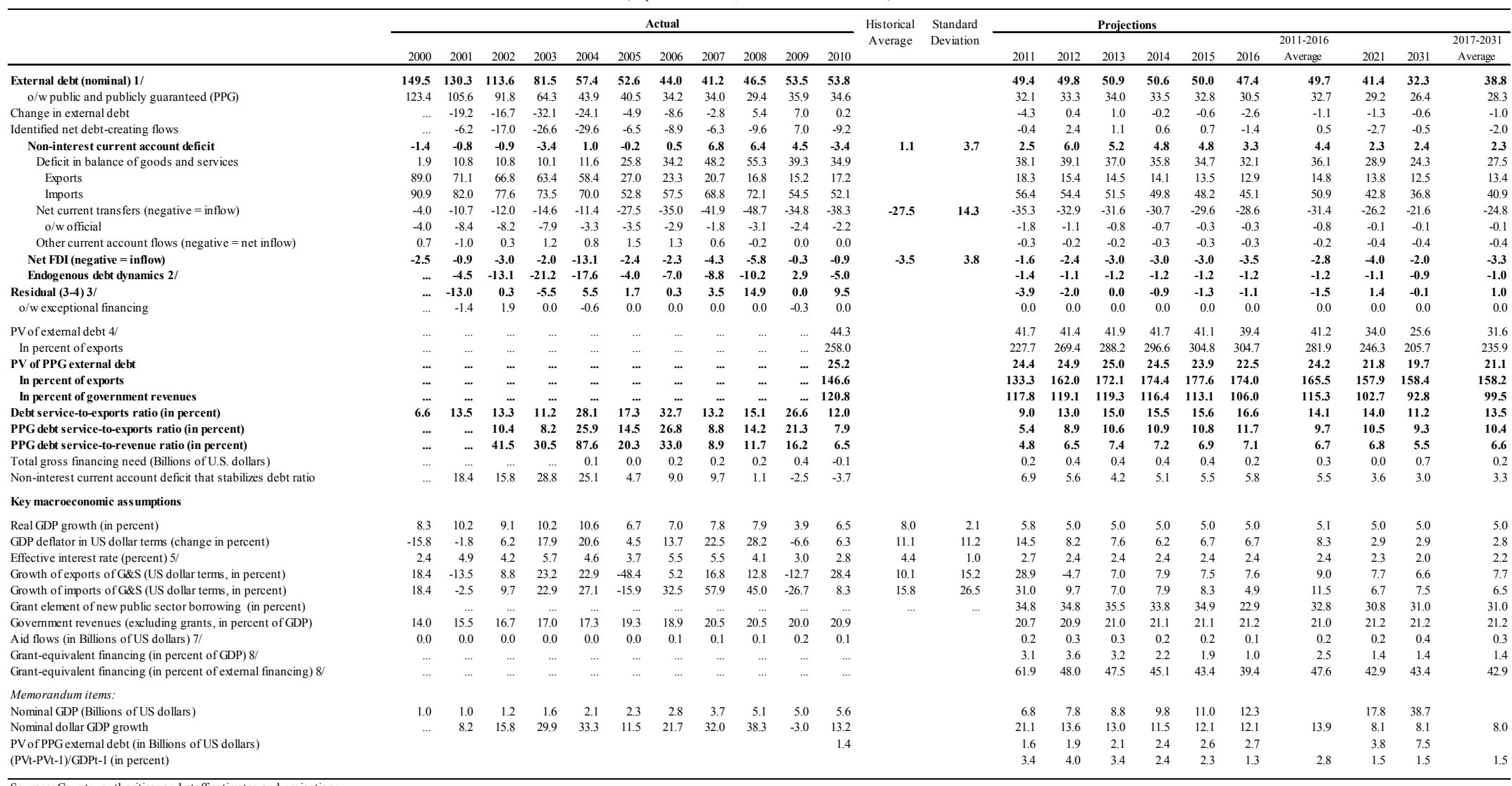

Sources: Country authorities; and staff estimates and pro
1/Includes both public and private sector external debt.

is period debt ratio, with $\mathrm{r}=$ nominal interest rate; $\mathrm{g}=$ real GDP growth rate, and $\rho=$ growth rate of GDP deflator in U.S. dollar tern

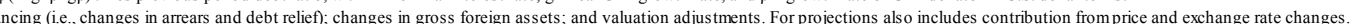

4/ Assumes that PV of private sector debt is equivalent to its face value.

6/ Historical averages and standard deviations are generally derived over the past 10 years, subject to data availability

8/ Grant-equivalent financing includes grants provided diect 
Table 1b.Tajikistan: Sensitivity Analysis for Key Indicators of Public and Publicly Guaranteed External Debt, 2011-2031 (In percent)

PV of debt-to GDP ratio

Baseline

A. Alternative Scenarios

A1. Key variables at their historical averages in 2011-2031 1/ A2. New public sector loans on less favorable terms in 2011-2031/2

A3. Alternative Scenario : High investment-low growth

\section{B. Bound Tests}

B1. Real GDP growth at historical average minus one standard deviation in 2012-2013 B2. Export value growth at historical average minus one standard deviation in 2012-2013 3/ B3. US dollar GDP deflator at historical average minus one standard deviation in 2012-2013 B4. Net non-debt creating flows at historical average minus one standard deviation in 2012-2013 4 B5. Combination of B1-B4 using one-half standard deviation shocks

B6. One-time 30 percent nominal depreciation relative to the baseline in 20125

\section{PV of debt-to-exports ratio}

\section{Baseline}

A. Alternative Scenarios

A1. Key variables at their historical averages in 2011-2031 1/ A2. New public sector loans on less favorable terms in 2011-2031/2

A3. Alternative Scenario : High investment-low growth

\section{B. Bound Tests}

B1. Real GDP growth at historical average minus one standard deviation in 2012-2013 B2. Export value growth at historical average minus one standard deviation in 2012-2013 3/ B3. US dollar GDP deflator at historical average minus one standard deviation in 2012-2013 B4. Net non-debt creating flows at historical average minus one standard deviation in 2012-2013 4/ B5. Combination of B1-B4 using one-half standard deviation shocks

B6. One-time 30 percent nominal depreciation relative to the baseline in 20125

$\begin{array}{rrrrrrrr}24 & 25 & 25 & 25 & 24 & 23 & \mathbf{2 2} & 20 \\ & & & & & & & \\ 24 & 19 & 15 & 12 & 9 & 7 & \mathbf{3} & -2 \\ 24 & 26 & 28 & 28 & 28 & 27 & \mathbf{2 9} & 30 \\ 23 & 26 & 28 & 29 & 29 & 28 & \mathbf{3 0} & 31\end{array}$

$\begin{array}{llllllll}24 & 24 & 24 & 24 & 23 & 22 & \mathbf{2 1} & 19 \\ 24 & 24 & 26 & 25 & 25 & 23 & \mathbf{2 2} & 20 \\ 24 & 26 & 28 & 28 & 27 & 26 & \mathbf{2 5} & 23 \\ 24 & 40 & 54 & 51 & 49 & 45 & \mathbf{3 9} & 25 \\ 24 & 33 & 41 & 40 & 38 & 35 & \mathbf{3 2} & 23 \\ 24 & 33 & 34 & 33 & 32 & 30 & \mathbf{3 0} & 27\end{array}$

PV of debt-to-revenue ratio

Baseline

$\begin{array}{llllllll}333 & 157 & 168 & 171 & 174 & 170 & \mathbf{1 5 5} & 156\end{array}$

$\begin{array}{llllllll}133 & 160 & 205 & 208 & 211 & 207 & \mathbf{1 8 6} & 182\end{array}$

$\begin{array}{llllllll}133 & 157 & 168 & 171 & 174 & 170 & \mathbf{1 5 5} & 156\end{array}$

$\begin{array}{llllllll}133 & 260 & 371 & 366 & 361 & 350 & \mathbf{2 8 2} & 200\end{array}$

$\begin{array}{llllllll}133 & 199 & 273 & 271 & 270 & 262 & \mathbf{2 1 9} & 175\end{array}$

$\begin{array}{llllllll}133 & 157 & 168 & 171 & 174 & 170 & \mathbf{1 5 5} & 156\end{array}$

A. Alternative Scenarios

A 1. Key variables at their historical averages in 2011-2031 1/

A2. New public sector loans on less favorable terms in 2011-2031/2

A3. Alternative Scenario : High investment-low growth

$\begin{array}{rrrrrrrr}118 & 90 & 74 & 57 & 42 & 32 & \mathbf{1 5} & -9 \\ 118 & 125 & 132 & 134 & 134 & 127 & \mathbf{1 3 7} & 142 \\ 113 & 126 & 134 & 137 & 135 & 130 & \mathbf{1 4 1} & 145 \\ & & & & & & & \\ & & & & & & & \\ 118 & 115 & 114 & 112 & 109 & 102 & \mathbf{9 9} & 90 \\ 118 & 116 & 123 & 121 & 117 & 109 & \mathbf{1 0 5} & 93 \\ 118 & 125 & 136 & 133 & 129 & 121 & \mathbf{1 1 8} & 106 \\ 118 & 191 & 258 & 244 & 230 & 213 & \mathbf{1 8 3} & 117 \\ 118 & 158 & 197 & 189 & 179 & 167 & \mathbf{1 4 8} & 107 \\ 118 & 160 & 161 & 158 & 153 & 143 & \mathbf{1 4 0} & 126\end{array}$

\section{B. Bound Tests}

B1. Real GDP growth at historical average minus one standard deviation in 2012-2013 B2. Export value growth at historical average minus one standard deviation in 2012-2013 3/ B3. US dollar GDP deflator at historical average minus one standard deviation in 2012-2013 B4. Net non-debt creating flows at historical average minus one standard deviation in 2012-2013 B5. Combination of B1-B4 using one-half standard deviation shocks B6. One-time 30 percent nominal depreciation relative to the baseline in 20125 
Table 1b.Tajikistan: Sensitivity Analysis for Key Indicators of Public and Publicly Guaranteed External Debt, 2011-2031 (continued) (In percent)

\begin{tabular}{|c|c|c|c|c|c|c|c|c|}
\hline & \multicolumn{8}{|c|}{ Projections } \\
\hline & 2011 & 2012 & 2013 & 2014 & 2015 & 2016 & 2021 & 2031 \\
\hline \multicolumn{9}{|c|}{ Debt service-to-exports ratio } \\
\hline Baseline & 5 & 9 & 11 & 11 & 11 & 12 & 10 & 9 \\
\hline \multicolumn{9}{|l|}{ A. Alternative Scenarios } \\
\hline A1. Key variables at their historical averages in 2011-2031 1/ & 5 & 8 & 8 & 7 & 7 & 6 & 2 & 0 \\
\hline A2. New public sector loans on less favorable terms in 2011-2031/2 & 5 & 8 & 10 & 11 & 12 & 12 & 13 & 15 \\
\hline A3. Alternative Scenario : High investment-low growth & 5 & 9 & 11 & 11 & 12 & 12 & 13 & 16 \\
\hline \multicolumn{9}{|l|}{ B. Bound Tests } \\
\hline B1. Real GDP growth at historical average minus one standard deviation in 2012-2013 & 5 & 8 & 10 & 10 & 10 & 10 & 9 & 9 \\
\hline B2. Export value growth at historical average minus one standard deviation in 2012-2013 3/ & 5 & 8 & 11 & 12 & 12 & 12 & 11 & 11 \\
\hline B3. US dollar GDP deflator at historical average minus one standard deviation in 2012-2013 & 5 & 8 & 10 & 10 & 10 & 10 & 9 & 9 \\
\hline B4. Net non-debt creating flows at historical average minus one standard deviation in 2012-2013 4/ & 5 & 8 & 12 & 14 & 14 & 14 & 19 & 14 \\
\hline B5. Combination of B1-B4 using one-half standard deviation shocks & 5 & 8 & 10 & 12 & 12 & 12 & 14 & 12 \\
\hline B6. One-time 30 percent nominal depreciation relative to the baseline in 20125 / & 5 & 8 & 10 & 10 & 10 & 10 & 9 & 9 \\
\hline
\end{tabular}

\section{Debt service-to-revenue ratio}

\section{Baseline}

\section{A. Alternative Scenarios}

A 1. Key variables at their historical averages in 2011-2031 1/ A2. New public sector loans on less favorable terms in 2011-2031/2

A3. Alternative Scenario : High investment-low growth

\section{B. Bound Tests}

B1. Real GDP growth at historical average minus one standard deviation in 2012-2013 B2. Export value growth at historical average minus one standard deviation in 2012-2013 3/ B3. US dollar GDP deflator at historical average minus one standard deviation in 2012-2013 B4. Net non-debt creating flows at historical average minus one standard deviation in 2012-2013 4/ B5. Combination of B1-B4 using one-half standard deviation shocks

B6. One-time 30 percent nominal depreciation relative to the baseline in 2012 5/

Memorandum item:

Grant element assumed on residual financing (i.e., financing required above baseline) 6/

1/ Variables include real GDP growth, growth of GDP deflator (in U.S. dollar terms), non-interest current account in percent of GDP, and non-debt creating flows.

2 / Assumes that the interest rate on new borrowing is by 2 percentage points higher than in the baseline., while grace and maturity periods are the same as in the baseline.

3 / Exports values are assumed to remain permanently at the lower level, but the current account as a share of GDP is assumed to return to its baseline level after the shock (implicitely assuming an offsetting adjustment in import levels).

4/ Includes official and private transfers and FDI

5/ Depreciation is defined as percentage decline in dollar/local currency rate, such that it never exceeds 100 percent

6/ Applies to all stress scenarios except for A2 (less favorable financing) in which the terms on all new financing are as specified in footnote 2. 
Table 2a. Tajikistan: Public Sector Debt Sustainability Framework, Baseline Scenario, 2009-2031

(In percent of GDP, unless otherwise indicated)

\begin{tabular}{|c|c|c|c|c|c|c|c|c|c|c|c|c|}
\hline & \multicolumn{3}{|c|}{ Actual } & \multicolumn{9}{|c|}{ Projections } \\
\hline & 2009 & 2010 & 2011 & 2012 & 2013 & 2014 & 2015 & 2016 & $\begin{array}{l}\text { 2011-16 } \\
\text { Average }\end{array}$ & 2021 & 2031 & $\begin{array}{l}2017-31 \\
\text { Average }\end{array}$ \\
\hline $\begin{array}{l}\text { Public sector debt } 1 / \\
\text { o/w foreign-currency denominated }\end{array}$ & $\begin{array}{l}36.6 \\
35.9\end{array}$ & $\begin{array}{l}36.7 \\
34.6\end{array}$ & $\begin{array}{l}34.2 \\
32.1\end{array}$ & $\begin{array}{l}35.5 \\
33.3\end{array}$ & $\begin{array}{l}37.3 \\
34.0\end{array}$ & $\begin{array}{l}37.6 \\
33.5\end{array}$ & $\begin{array}{l}37.5 \\
32.8\end{array}$ & $\begin{array}{l}35.6 \\
30.5\end{array}$ & & $\begin{array}{l}34.2 \\
29.2\end{array}$ & $\begin{array}{l}29.8 \\
26.4\end{array}$ & \\
\hline Change in public sector debt & 6.4 & 0.1 & -2.4 & 1.3 & 1.8 & 0.3 & -0.1 & -1.9 & & -0.3 & -0.5 & \\
\hline Identified debt-creating flows & 7.7 & -1.0 & -0.1 & -0.5 & -1.1 & -1.6 & -1.9 & -1.4 & & 0.3 & -2.4 & \\
\hline Primary deficit & 4.7 & 3.1 & 4.8 & 3.6 & 2.8 & 1.9 & 1.7 & 2.2 & 2.4 & 2.3 & -0.6 & 2.0 \\
\hline Revenue and grants & 23.4 & 23.2 & 22.8 & 22.4 & 22.2 & 21.9 & 21.7 & 21.8 & & 21.8 & 21.8 & \\
\hline of which: grants & 3.4 & 2.3 & 2.1 & 1.5 & 1.3 & 0.8 & 0.6 & 0.6 & & 0.6 & 0.6 & \\
\hline Primary (noninterest) expenditure & 28.1 & 26.2 & 27.6 & 26.0 & 25.0 & 23.8 & 23.4 & 24.0 & & 24.1 & 21.2 & \\
\hline Automatic debt dynamics & 3.0 & -5.2 & -4.8 & -4.0 & -3.8 & -3.5 & -3.5 & -3.6 & & -2.0 & -1.8 & \\
\hline Contribution from interest rate/growth differential & -1.1 & -2.3 & -2.3 & -2.0 & -2.0 & -2.1 & -2.1 & -2.2 & & -1.8 & -1.5 & \\
\hline Contribution from real exchange rate depreciation & 4.1 & -2.9 & -2.6 & -2.0 & -1.8 & -1.4 & -1.4 & -1.4 & & $\ldots$ & $\ldots$ & \\
\hline Other identified debt-creating flows & -0.1 & 1.1 & -0.1 & 0.0 & 0.0 & 0.0 & 0.0 & 0.0 & & 0.0 & 0.0 & \\
\hline Residual, including asset changes & -1.3 & 1.0 & -2.3 & 1.7 & 2.8 & 1.9 & 1.8 & -0.5 & & -0.6 & 1.9 & \\
\hline \multicolumn{13}{|l|}{ Other S ustainability Indicators } \\
\hline PV of public sector debt & 0.7 & 27.2 & 26.5 & 27.0 & 28.3 & 28.6 & 28.6 & 27.6 & & 26.8 & 23.1 & \\
\hline $\mathrm{o} / \mathrm{w}$ foreign-currency denominated & 0.0 & 25.2 & 24.4 & 24.9 & 25.0 & 24.5 & 23.9 & 22.5 & & 21.8 & 19.7 & \\
\hline $\mathrm{o} / \mathrm{w}$ external & $\ldots$ & 25.2 & 24.4 & 24.9 & 25.0 & 24.5 & 23.9 & 22.5 & & 21.8 & 19.7 & \\
\hline Gross financing need $2 /$ & 5.4 & 3.7 & 5.4 & 4.1 & 3.3 & 2.5 & 2.3 & 2.8 & & 3.0 & -0.1 & \\
\hline $\mathrm{PV}$ of public sector debt-to-revenue and grants ratio (in percent) & 3.2 & 117.6 & 116.0 & 120.6 & 127.3 & 130.7 & 131.5 & 126.4 & & 122.9 & 105.8 & \\
\hline $\mathrm{PV}$ of public sector debt-to-revenue ratio (in percent) & 3.7 & 130.5 & 127.8 & 129.5 & 135.0 & 135.9 & 135.0 & 129.8 & & 126.3 & 108.7 & \\
\hline o/w external $3 /$ & $\ldots$ & 120.8 & 117.8 & 119.1 & 119.3 & 116.4 & 113.1 & 106.0 & & 102.7 & 92.8 & \\
\hline Debt service-to-revenue and grants ratio (in percent) $4 /$ & 3.0 & 2.8 & 2.7 & 2.2 & 2.3 & 2.6 & 2.9 & 2.9 & & 3.1 & 2.7 & \\
\hline Debt service-to-revenue ratio (in percent) $4 /$ & 3.5 & 3.1 & 3.0 & 2.3 & 2.4 & 2.7 & 3.0 & 3.0 & & 3.2 & 2.8 & \\
\hline Primary deficit that stabilizes the debt-to-GDP ratio & -1.6 & 3.0 & 7.2 & 2.3 & 1.0 & 1.7 & 1.8 & 4.1 & & 2.6 & -0.2 & \\
\hline \multicolumn{13}{|l|}{ Key macroeconomic and fiscal assumptions } \\
\hline Real GDP growth (in percent) & 3.9 & 6.5 & 5.8 & 5.0 & 5.0 & 5.0 & 5.0 & 5.0 & 5.0 & 5.0 & 5.0 & 5.0 \\
\hline Average nominal interest rate on forex debt (in percent) & 2.1 & 1.9 & 1.8 & 1.4 & 1.4 & 1.4 & 1.5 & 1.4 & 1.4 & 1.5 & $1.5^{\circ}$ & 1.5 \\
\hline Average real interest rate on domestic debt (in percent) & -2.4 & 0.9 & -10.5 & -8.3 & -6.6 & -5.0 & -4.7 & $-4.6^{7}$ & -5.9 & 0.2 & $0.3^{\mathbf{r}}$ & 0.2 \\
\hline Real exchange rate depreciation (in percent,+ indicates depreciation) & 14.6 & -8.7 & -7.9 & & $\ldots$ & $\ldots$ & $\ldots$ & $\ldots$ & $\ldots$ & $\ldots$ & $\ldots$ & $\ldots$ \\
\hline Inflation rate (GDP deflator, in percent) & 12.7 & 12.5 & 18.6 & 15.8 & 13.6 & 11.0 & 11.0 & 11.0 & 12.5 & 6.0 & 6.0 & 6.0 \\
\hline Growth of real primary spending (deflated by GDP deflator, in percent) & 0.1 & 0.0 & 0.1 & 0.0 & 0.0 & 0.0 & 0.0 & 0.1 & 0.0 & 0.1 & -0.1 & 0.0 \\
\hline Grant element of new external borrowing (in percent) & $\ldots$ & $\ldots$ & 34.8 & 34.8 & 35.5 & 33.8 & 34.9 & 22.9 & 32.4 & 30.8 & 31.0 & $\ldots$ \\
\hline
\end{tabular}

Sources: Country authorities; and staff estimates and projections.

$1 /$ [Indicate coverage of public sector, e.g., general government or nonfinancial public sector. Also whether net or gross debt is used.]

$2 /$ Gross financing need is defined as the primary deficit plus debt service plus the stock of short-term debt at the end of the last period.

3 / Revenues excluding grants.

4/ Debt service is defined as the sum of interest and amortization of medium and long-term debt.

$5 /$ Historical averages and standard deviations are generally derived over the past 10 years, subject to data availability. 
Table 2b. Tajikistan: Sensativity Analisys for Key Indicators of Public Debt, 2011-2031

\begin{tabular}{|c|c|c|c|c|c|c|c|c|}
\hline & \multicolumn{8}{|c|}{ Projections } \\
\hline & 2011 & 2012 & 2013 & 2014 & 2015 & 2016 & 2021 & 2031 \\
\hline \multicolumn{9}{|l|}{ PV of Debt-to-GDP Ratio } \\
\hline Baseline & 26 & 27 & 28 & 29 & 29 & 28 & 27 & 23 \\
\hline \multicolumn{9}{|l|}{ A. Alternative scenarios } \\
\hline A1. Real GDP growth and primary balance are at historical averages & 26 & 24 & 24 & 23 & 22 & 20 & 15 & 11 \\
\hline A2. primary balance is unchanged from 2011 & 26 & 28 & 32 & 35 & 38 & 40 & 53 & 85 \\
\hline A3. Permanently lower GDP growth 1/ & 26 & 27 & 29 & 30 & 30 & 30 & 34 & 48 \\
\hline A4. Alternative scenario: Contingent liability & 26 & 37 & 38 & 39 & 39 & 38 & 38 & 36 \\
\hline \multicolumn{9}{|l|}{ B. Bound tests } \\
\hline B1. Real GDP growth is at historical average minus one standard deviations in 2012-2013 & 26 & 27 & 27 & 27 & 27 & 25 & 23 & 15 \\
\hline B2. primary balance is at historical average minus one standard deviations in 2012-2013 & 26 & 28 & 31 & 31 & 31 & 30 & 29 & 26 \\
\hline B3. Combination of B1-B2 using one half standard deviation shocks & 26 & 26 & 27 & 26 & 26 & 24 & 19 & 6 \\
\hline B4. One-time 30 percent real depreciation in 2012 & 26 & 36 & 36 & 36 & 35 & 34 & 32 & 29 \\
\hline \multicolumn{9}{|c|}{ PV of Debt-to-Revenue Ratio 2/ } \\
\hline Baseline & 116 & 121 & 127 & 131 & 131 & 126 & 123 & 106 \\
\hline \multicolumn{9}{|l|}{ A. Alternative scenarios } \\
\hline A1. Real GDP growth and primary balance are at historical averages & 116 & 109 & 107 & 105 & 102 & 93 & 69 & 53 \\
\hline A2. primary balance is unchanged from 2011 & 116 & 126 & 142 & 159 & 175 & 182 & 242 & 391 \\
\hline A3. Permanently lower GDP growth 1/ & 116 & 122 & 130 & 135 & 138 & 136 & 153 & 219 \\
\hline A4. Alternative scenario: Contingent liability & 116 & 165 & 173 & 178 & 179 & 175 & 175 & 166 \\
\hline \multicolumn{9}{|l|}{ B. Bound tests } \\
\hline B1. Real GDP growth is at historical average minus one standard deviations in 2012-2013 & 116 & 119 & 123 & 125 & 123 & 117 & 104 & 67 \\
\hline B2. primary balance is at historical average minus one standard deviations in 2012-2013 & 116 & 124 & 137 & 141 & 142 & 137 & 134 & 119 \\
\hline B3. Combination of B1-B2 using one half standard deviation shocks & 116 & 116 & 121 & 121 & 118 & 109 & 87 & 28 \\
\hline B4. One-time 30 percent real depreciation in 2012 & 116 & 163 & 163 & 163 & 160 & 154 & 147 & 132 \\
\hline
\end{tabular}

Debt Service-to-Revenue Ratio 2/

Baseline

A. Alternative scenarios

A1. Real GDP growth and primary balance are at historical averages

A2. primary balance is unchanged from 2011

A3. Permanently lower GDP growth $1 /$

A4. Alternative scenario: Contingent liability

$\begin{array}{rrrrrrrr}3 & 2 & 1 & 0 & 0 & 0 & 0 & 0 \\ 3 & 2 & 3 & 5 & 7 & 10 & 16 & 33 \\ 3 & 2 & 2 & 3 & 3 & 4 & 6 & 14 \\ 3 & 2 & 10 & 10 & 10 & 10 & 9 & 10\end{array}$

\section{B. Bound tests}

B1. Real GDP growth is at historical average minus one standard deviations in 2012-2013

B2. primary balance is at historical average minus one standard deviations in 2012-2013

B3. Combination of B1-B2 using one half standard deviation shocks

B4. One-time 30 percent real depreciation in 2012

B5. 10 percent of GDP increase in other debt-creating flows in 2012

$\begin{array}{rrrrrrrr}3 & 2 & 2 & 2 & 2 & 2 & 1 & -1 \\ 3 & 2 & 3 & 4 & 5 & 5 & 4 & 4 \\ 3 & 2 & 2 & 2 & 2 & 1 & 0 & -6 \\ 3 & 3 & 3 & 4 & 4 & 4 & 5 & 6 \\ 3 & 2 & 10 & 10 & 10 & 10 & 9 & 10\end{array}$

Sources: Country authorities; and IMF staff estimates and projections.

1/ Assumes that real GDP growth is at baseline minus one standard deviation divided by the square root of the length of the projection period.

2/ Revenues are defined inclusive of grants. 


\section{INTERNATIONAL MONETARY FUND}

\section{Public Information Notice}

EXTERNAL

RELATIONS DEPARTMENT
Public Information Notice (PIN) No. 11/60 FOR IMMEDIATE RELEASE May 25, 2011
International Monetary Fund $70019^{\text {th }}$ Street, NW

Washington, D. C. 20431 USA

\section{IMF Executive Board Concludes 2011 Article IV Consultation and Fourth Review Under the ECF Arrangement with Tajikistan}

On May 11, 2011, the Executive Board of the International Monetary Fund (IMF) concluded the 2011 Article IV consultation and fourth review under the Extended Credit Facility (ECF) arrangement with Tajikistan. ${ }^{1}$

\section{Background}

Tajikistan has begun to recover from the global crisis, which negatively affected inward remittances, exports of such key products as aluminum and cotton, and foreign direct investment. In 2010, real GDP growth reached 6.5 percent, up from 3.9 percent in 2009 , despite rail traffic disruptions in the first half of the year. Stronger hydroelectricity production helped to boost industrial activity, while trade and services benefited from a recovery of remittances in line with the economic rebound in Russia. However, in response to increased international food and fuel prices in the second half of the year, headline inflation accelerated to 9.8 percent by end-2010. Despite the pick-up in remittances, which are normally associated with higher imports, the trade balance improved and the external current account shifted to a surplus of 2.2 percent of GDP in 2010, compared with an average 5 percent deficit during 2005-09. The lagged impact of real exchange rate depreciation, disruptions to rail transit in the first part of 2010, and a slowdown in external loan disbursements for the public investment program underpinned this shift. The overall balance of payments remained positive.

\footnotetext{
${ }^{1}$ Under Article IV of the IMF's Articles of Agreement, the IMF holds bilateral discussions with members, usually every year. A staff team visits the country, collects economic and financial information, and discusses with officials the country's economic developments and policies. On return to headquarters, the staff prepares a report, which forms the basis for discussion by the Executive Board. At the conclusion of the discussion, the Managing Director, as Chairman of the Board, summarizes the views of Executive Directors, and this summary is transmitted to the country's authorities. An explanation of any qualifiers used in summing up can be found here: http://www.imf.org/external/np/sec/misc/qualifiers.htm.
} 
The government achieved an overall fiscal deficit (excluding externally financed investment) of 0.4 percent of GDP, compared with a budgeted deficit of 1 percent of GDP, mainly on account of lower than projected current spending, particularly on wages. The National Bank of Tajikistan (NBT) continued targeting reserve money growth, while limiting interventions in the foreign exchange market to smoothing excess volatility and building reserves. At end-2010, gross international reserves reached US $\$ 447$ million, equivalent to 1.4 month of imports. However, liquidity support from the NBT to commercial banks started to rise sharply in the second half of 2010 and into 2011-partly to finance imports of food and fuel products for strategic reservesincreasing the risk of compromising monetary policy targets going forward and reflecting continued weaknesses in the banking sector.

Economic prospects for 2011 are good, but not without risks. Growth is projected to reach at least 5.8 percent, in line with the continued growth of key regional partners. Prospects for cotton are also relatively good given high international prices for this commodity. However, continued increases in future food and energy prices are likely to fuel inflation and aggravate poverty. Further disruptions in rail traffic-one of the key import and export arteries for landlocked Tajikistan—could weigh on growth. Remaining vulnerabilities in the financial and state enterprise sectors could also pose a quasi-fiscal risk and be a drag on private sector growth.

Tajikistan's financial system remains vulnerable, despite recent improvements in some financial soundness indicators. Although private sector credit (excluding activities related to the write-off of loans held by Kredit Invest as part of the cotton sector debt resolution) recovered through the course of the year and classified loans have recently declined, the extent to which this reflects a lasting improvement is uncertain. Profitability turned positive in the fourth quarter, but remains minimal. Recent gains appear fragile, and linked to restructuring of assets rather than an underlying improvement in profitability.

\section{Executive Board Assessment}

Executive Directors considered that Tajikistan's economic performance has been generally satisfactory and that economic growth is gaining momentum. Directors agreed that the most pressing challenge for policymakers is to support the recovery, while addressing risks to macroeconomic stability from rising commodity prices and worsening terms of trade. They also noted that, over the medium term, sustained economic growth and poverty reduction hinge on additional efforts to strengthen the fiscal position, provide buffers against shocks, and promote market oriented reforms.

Directors commended the authorities for the commitment to fiscal discipline shown under the program and considered this year's fiscal plans appropriate. They noted, however, the importance of budgetary consolidation over the medium term to safeguard 
debt sustainability. Along the fiscal adjustment path, greater room for needed social and infrastructure spending calls for revenue-enhancing measures and a better balance between current and capital expenditure.

Directors agreed that monetary policymakers should address emerging inflation risks without undermining the recovery. Curbing liquidity lending by the central bank would be an important step in the right direction. Directors also encouraged the authorities to develop over the medium term a framework for direct cash support to the poor as a more targeted response to surges in international commodity prices and imported inflation.

Directors observed that, despite some improvement in financial indicators, the banking system remains fragile and financial intermediation limited. They cautioned that fiscal liabilities might emerge if weaknesses at banks are not addressed. In this regard, Directors urged the authorities to press ahead with their strategy to tackle these vulnerabilities and reduce financial sector dependence on direct liquidity support.

Directors agreed that structural reforms, including to improve governance and the business environment, should remain a top policy priority. They welcomed progress in establishing a framework for agricultural financing, and encouraged the authorities to continue cooperating with donors to push these reforms forward. Directors also welcomed plans to improve the business climate through a reform of the tax regime and improved transparency and accountability at state-owned enterprises.

Public Information Notices (PINs) form part of the IMF's efforts to promote transparency of the IMF's views and analysis of economic developments and policies. With the consent of the country (or countries) concerned, PINs are issued after Executive Board discussions of Article IV consultations with member countries, of its surveillance of developments at the regional level, of post-program monitoring, and of ex post assessments of member countries with longer-term program engagements. PINs are also issued after Executive Board discussions of general policy matters, unless otherwise decided by the Executive Board in a particular case. 
Republic of Tajikistan: Selected Economic Indicators, 2007-11

\begin{tabular}{|c|c|c|c|c|c|}
\hline & $\begin{array}{l}2007 \\
\text { Act }\end{array}$ & $\begin{array}{l}2008 \\
\text { Act }\end{array}$ & $\begin{array}{l}2009 \\
\text { Act. }\end{array}$ & $\begin{array}{l}2010 \\
\text { Act. }\end{array}$ & $\begin{array}{l}2011 \\
\text { Proj. }\end{array}$ \\
\hline Production and prices & \multicolumn{5}{|c|}{ (Annual change in percent) } \\
\hline Real GDP & 7.8 & 7.9 & 3.9 & 6.5 & 5.8 \\
\hline $\mathrm{CPI}$ inflation (period average) & 13.2 & 20.4 & 6.5 & 6.5 & 13.9 \\
\hline General Government & \multicolumn{5}{|c|}{ (In percent of GDP) } \\
\hline Total Revenue and grants & 22.5 & 22.1 & 23.4 & 23.2 & 22.8 \\
\hline Of which: grants & 2.0 & 1.6 & 3.4 & 2.3 & 2.1 \\
\hline Expenditure and net lending & 27.7 & 27.6 & 28.8 & 26.9 & 28.2 \\
\hline Of which: social expenditure $1 /$ & 7.5 & 7.3 & 9.0 & 9.0 & 9.2 \\
\hline Of which: capital expenditure 2/ & 14.1 & 13.6 & 13.3 & 10.9 & 12.2 \\
\hline \multicolumn{6}{|l|}{ Overall balance } \\
\hline Excluding externally financed investment & 2.5 & 1.4 & -0.5 & -0.4 & -1.0 \\
\hline Including externally financed investment & -5.3 & -5.5 & -5.4 & -3.7 & -5.4 \\
\hline Monetary Indicators & \multicolumn{5}{|c|}{ (Annual change in percent, unless otherwise indicated) } \\
\hline Broad money & 78.8 & 6.3 & 39.6 & 26.2 & 22.1 \\
\hline Velocity of broad money (end-of-period) & 4.7 & 5.8 & 5.1 & 4.9 & 5.0 \\
\hline External sector & \multicolumn{5}{|c|}{ (In millions of U.S. dollar, unless otherwise indicated) } \\
\hline Exports of goods and services & 767 & 865 & 755 & 970 & 1,250 \\
\hline Imports of goods and services & 2,555 & 3,703 & 2,714 & 2,940 & 3,851 \\
\hline Current account balance & -319 & -392 & -295 & 123 & -253 \\
\hline In percent of GDP & -8.6 & -7.6 & -5.9 & 2.2 & -3.7 \\
\hline Gross official reserves $3 /$ & 85 & 150 & 278 & 447 & 557 \\
\hline In months of next year's imports 4/ & 0.3 & 0.7 & 1.2 & 1.4 & 1.6 \\
\hline
\end{tabular}

Sources: Tajik authorities; and IMF staff projections.

$1 /$ Includes current and capital spending on social protection, education and health.

$2 /$ Includes domestically and externally financed investments.

3/ Gross reserves are net of the pledged deposits of the NBT; includes SDR 81.2 million allocation in Q3 2009.

4/ Excludes electricity, which is on barter basis, and imports for projects financed with loans from China. 


\section{Statement by Mr. Weber and Ms. Zavkiev on Tajikistan May 11, 2011}

1. On behalf of our Tajik authorities, we thank the staff for the constructive policy discussions and valuable support in pursuing the objectives of the Fund arrangement. The authorities remain strongly committed to a close relationship with the Fund, acknowledging the importance of financial and technical assistance for preserving macroeconomic stability and implementing a broad reform agenda that is also supported by the international donor community. They ask the Executive Board to favorably consider their request as outlined in the Letter of Intent and to agree to the completion of this review under the ECF.

2. Tajikistan remains vulnerable to exogenous shocks, a situation exacerbated by the country's geography with limited options for road and rail transport. Achieving energy reliability and food security are predominant concerns. Despite notable progress in establishing stronger foundations for growth, the Tajik government continues to grapple with the challenges related to a narrow export base, banking sector weaknesses, the dependence on remittance inflows, and poverty and unemployment. It strives to remedy inefficiencies in infrastructure investment and in the state enterprise sector. The authorities concur with the staff's appraisal with a view to addressing these issues.

3. Tajikistan has adhered to all of the program's performance criteria, with the exception of the continuous criterion on the accumulation of new external arrears. The authorities very much regret that a breach occurred and they acknowledge that the two incidences constitute a misreporting. They have, however, acted promptly in clearing these arrears and in taking credible remedial action, as recognized by staff. They appreciate the staff's conclusion that the arrears were so small as to have no material impact on the assessment of program performance or on debt sustainability, and that they can thus be handled on a de minimis basis. The authorities kindly ask the Board for a waiver for nonobservance of this criterion.

4. Most of the program's quantitative indicative targets were also met. Liquidity lending to banks by the National Bank of Tajikistan (NBT) above the ceiling was to a substantial extent a response to the sudden increase in the price of imported food and fuel aimed at ensuring sufficient supply. This measure stabilized markets and sought to prevent public unrest. However, the authorities are aware of potential stability and fiscal risks of such lending and they expect to scale it down in conformity with the targets under the program. The floor on social expenditure was undershot due to concerns to meet the overall fiscal target, an outcome that helped prevent fueling a wage-price spiral. The increase in public wages and salaries for 2010 was contained at 10 percent rather than reaching the envisaged 15 percent, which contributed to lower social spending than anticipated. Tajikistan has met all structural benchmarks and structural reforms to improve transparency and governance progressed well.

5. The Fund arrangement has proved an effective policy framework to maintain macroeconomic stability and advance structural reforms. The economy has emerged from the 
effects of the global financial crisis and is expected to grow by close to 6 percent in 2011 . Given Tajikistan's external vulnerabilities, the flexible exchange rate has served as an important shock absorber and has allowed for the accumulation of significant reserves. The authorities concur with staff that the current account surplus of 2.2 percent of GDP seems to be transitory.

6. The monetary authorities have achieved single digit inflation but the inflation rate is projected to rise again above 12 percent in 2011 due to the recent upward trend of international prices for food and fuel. Monetary policy will continue to target reserve money as the nominal anchor with the focus on containing inflation, while maintaining the flexible exchange rate regime. The authorities will further enhance the transparency and governance of the NBT, including NBT recapitalization, in line with the recommendations of last year's safeguards assessment.

7. Fiscal discipline has been maintained with an overall fiscal deficit of 0.4 percent of GDP, below the 1 percent of GDP envisaged under the program. Given the need to meet pressing social and development needs with limited resources, a budget deficit of 1 percent of GDP is targeted for 2011. This target does not jeopardize debt sustainability by keeping public and publicly-guaranteed debt below the ceiling of 40 percent of GDP. External borrowing will be restricted to concessional loans.

8. In the area of public financial management, the reform agenda encompasses a review of tax policy, for which Fund assistance has been requested, and improvements in tax administration. This agenda includes increasing the number of taxpayers covered by the Large Taxpayer Inspectorate, introducing a full Treasury Single Account system at the national level, and implementing an electronic financial management information system. Further measures are envisaged, as a matter of priority, to address arrears problems in SOEs in order to put them on a sound financial footing and ensure their transparency and governance. These steps will include the publication of the externally audited financial statements of large SOEs such as Tajikistan Aluminum Company (TALCO) and Tajik Electricity Company Barki Tojik. The audit report of Roghun OJSC will be finalized and released by end-June, as included in the structural benchmarks. The new SOE Unit at the Ministry of Finance will closely monitor the financial situation of the SOEs going forward.

9. Tajikistan's economic policy and development strategy over the medium-term focuses on safeguarding macroeconomic stability, developing the country's comparative advantage in hydroelectricity power production, accelerating structural reforms, and supporting the vulnerable segments of society. The authorities intend to further strengthen the governance and transparency of public sector institutions and enterprises and enhance the role of the private sector. They are committed to protect social spending from expenditure cuts and to develop a more targeted and effective system of social transfers with the help of the World Bank. 